\title{
Challenges and Opportunities for Bio-oil Refining: A Review
}

\author{
Anamaria Paiva Pinheiro Pires ${ }^{1}$, Jesus Arauzo ${ }^{2}$, Isabel Fonts ${ }^{2}$, Marcelo E. Domine ${ }^{3}$, Alberto \\ ${\text { Fernández } \text { Arroyo }^{3} \text {, Marta Estrella Garcia-Perez }}^{4}$, Jorge Montoya ${ }^{5}$, Farid Chejne Jane ${ }^{5}$, Peter \\ Pfromm $^{6}$, Manuel Garcia-Perez ${ }^{1 *}$ \\ ${ }^{1}$ Biological Systems Engineering Department, Washington State University, 99163 \\ ${ }^{2}$ Thermochemical Processes Group (GPT), Aragon Institute for Engineering Research (I3A), \\ Universidad de Zaragoza, Mariano Esquillor, s/n, 50018, Zaragoza, Spain \\ ${ }^{3}$ Instituto de Tecnología Química (UPV-CSIC), Universitat Politècnica de València-Consejo \\ Superior de Investigaciones Científicas, Avda. de los Naranjos s/n, 46022, Valencia, Spain \\ ${ }^{4}$ Facultad de Quimico Farmacobiologia, Universidad Michoacana de San Nicolas de Hidalgo, \\ Morelia, Mich., Mexico \\ ${ }^{5}$ Facultad de Minas, Universidad Nacional de Colombia, Colombia \\ ${ }^{6}$ The Gene and Linda Voiland School or Chemical Engineering and Bioengineering, Washington \\ State University, 99163
}

(Paper to be submitted to Energy \& Fuels)

Abstract: Bio-oil derived from fast pyrolysis of lignocellulosic materials is among the most complex and inexpensive raw oils that can be produced today. Although commercial or demonstration scale fast pyrolysis units can readily produce this oil, this industry has not grown to significant commercial impact due to the lack of bio-oil market pull. This paper is a review of the challenges and opportunities for bio-oil upgrading and refining. Pyrolysis oil consists of six major fractions. (water 15-30 wt.\%, light oxygenates, 8-26 wt. \%, mono-phenols, 2-7 wt.\%, water insoluble oligomers derived from lignin $15-25 \mathrm{wt} . \%$, and water soluble havey molecules 10-30 wt.\%). The composition of water soluble oligomers is relatively poorly studied. In the 1880s bio-oil refining (formally known as wood distillation) targeted the separation and commercialization of C1-C4 light oxygenated compounds to produce methanol, acetic acid and acetone with the commercialization of the lignin derived water insoluble fraction for preserving 
wooden sailing vessels against rot. More recently Ensyn extracted and commercialized condensed natural smoke as a food additive. Most research efforts in the last twenty years have focused on the two-step hydrotreatment concept for the production of transportation fuels. In spite of major progress this concept remains at the demonstration. In this review, the opportunities and progress to separate bio-oil fractions and chemicals, mainly acetic acid (HAc), hydroxyacetaldehyde (HHA) and acetol, and convert them into value added co-products are thoroughly discussed. In spite of the large number of separation schemes and products tested, very few of them have been studied as part of fully integrated bio-oil refinery concepts. The synthesis, techno-economic and environmental evaluation of novel integrated bio-oil refinery concepts is likely to become a subject of intense research activity in the coming years.

\section{${ }^{*}$ Corresponding author:}

Manuel Garcia-Perez, Associate Professor, Biological Systems Engineering, WSU

LJ Smith, Room 205, Pullman, WA, 99164-6120

Phone: 509-335-7758, e-mail: mgarcia-perez@wsu.edu 


\section{Introduction}

The focus of this investigation is the chemistry, refining, fractionation and products of what is generally called fast pyrolysis bio-oil. Fast pyrolysis is a relatively mature thermochemical technology converting between 60 and $70 \mathrm{wt}$ \% of lignocellulosic materials into a liquid called "pyrolysis oil" or "bio-oil". Besides pyrolysis oil, the products of fast pyrolysis of biomass are gases and char. Liquid pyrolysis oils obtained from fast pyrolysis are generally a dark red to dark brown, acidic, single phase, and relatively low viscocity $\left(50-672 \mathrm{cSt} \text { at } 20{ }^{\circ} \mathrm{C}\right)^{1}$. This oil typically contains between 14 and $30 \mathrm{wt}$ \% of water and the remainder (70-86 wt. \%) are oxygenated organic compounds (between 38 and 44 wt. \% oxygen in dry basis) ${ }^{2}$. The carbon content of the organics is typically around $50 \mathrm{wt}$ \% (dry basis) ${ }^{2}$. Pyrolysis oil is virtually immiscible with hydrocarbons, shows some miscibility with water and is completely soluble in low molecular weight alcohols ${ }^{3}$. According to Ensyn $(2017)^{4}$, fast pyrolysis oil production from renewable resources could reach 0.3 billion barrels of bio-oil per day (or $4 \%$ of the current US consumption of 7.26 billion barrels of crude oil per day). The lack of economically viable bio-oil refining technologies is a main hurdle to deploy this technology.

There are excellent reviews on biomass pyrolysis $^{5-11}$, bio-oil chemistry ${ }^{12}$, bio-oil fuel quality and combustion $^{13}$ and bio-oil upgrading and refining $6,9,14-23$. A book chapter on pyrolysis oil biorefinery was recently published by Meier (2017) ${ }^{1}$. Based on our Scopus survey with the key words "pyrolysis oil refining" The number of paper in this area has been steadily growing: 19801990 (130 papers), 1990-2000 (204 papers), 2000-2010 (598 papers), 2010-2017 (2,472 papers). The increase in the number of publications in bio-oil chemistry and refining in the last seven years and the lack of critical reviews in this area motivate this work. Thus, the main goal of this paper is to summarize our current understanding of bio-oil chemistry, the state of the art of biooil refining schemes described in the literature, the progresses made in bio-oil fractionation, products purification, the new products developed from bio-oil fractions, and the potential to develop new bio-oil refining schemes. In the first section, the overall composition of bio-oil in terms of independent compounds, chemical families and functional groups is presented. In the next section we review existing bio-oil refinery concepts and thoroughly discuss their advantages and disadvantages. The third section is devoted to a review of bio-oil fractionation and 
purification techniques. Strategies for biofuels production are discussed in section four. Bio-oil derived products are discussed in the last section.

\section{Bio-oil Composition}

The study of bio-oil chemical composition has been the subject of active research in the last twenty years ${ }^{2,24-35}$. Pyrolysis oil contains numerous oxygenated compounds, which include carboxylic acids, water, alcohols, esthers, anhydrosugars, furanics, phenolics, aldehydes, and ketones covering a wide range of molecular weights and functionalities ${ }^{2,24,29,30,36-41}$. The specific composition is directly related to the feedstock and the conditions used in their production ${ }^{42-44}$.

Water is typically quantified by Karl Fischer titration ${ }^{2}$ and is the most abundant bio-oil compound accounting between 15 and 30 wt. $\%^{2}$ (See Figure 1). Water forms mostly from dehydration reactions of carbohydrate depolymerized products in the liquid intermediate ${ }^{44}$. Gas Chromatography/Mass Spectroscopy (GC/MS) is by far the most common technique for the quantification of the pyrolysis oil organic volatile fraction ${ }^{2,24,27,45}$. GC/MS detectable compounds typically account for between 30 and $40 \mathrm{wt} . \%^{2}$. Table 2 shows the range of compounds quantified by GC/MS reported in the literature. Only four molecules (glycoaldehyde, acetic acid, acetol and levoglucosan) are found in quantities sufficiently high (>5 wt. \%) to justify their separation and commercialization as chemicals. Methanol can also be produced in quantities justifying its commercialization but hardwood has to be used as feedstock. The remainder of the oil if refined is likely to be commercialized as fractions (mono-phenols, pyrolytic lignin, anhydrosugars, pyrolytic humins, and hybrid oligomers).

Because bio-oil consists of hundreds of compounds with concentrations below $0.5 \mathrm{wt}$ \% $\%$ it is desirable to express their chemical composition in terms of few chemical groups or families ${ }^{24}$. This idea was first proposed by Hallet and Clark ${ }^{46}$. The authors ${ }^{46}$ modeled bio-oil evaporation rates using a model based on this characterization scheme ${ }^{46}$. In DTG-FTIR studies with bio-oils doped with pure compounds (butyric acid, syringol, syringaldehyde, levoglucosan), Stankovikj et al. ${ }^{29}$ observed that the compound vapor pressures were depressed in pyrolysis oils. The authors described bio-oil composition in several families based on their chemical composition and thermal behavior (see Figure 1). The first family is the $\mathrm{C} 2-\mathrm{C} 4$ compounds (mainly hydroxyacetaldehyde, acetol and acetic acid) typically quantified by GC/MS ${ }^{2,42,47-49}$ (see Table 
2). This fraction is formed from carbohydrates fragmentation reactions and represents between 8 and 26 wt. \% of the oil ${ }^{2,50}$ (See Figure 1). The second family is formed by mono-phenols with small quantities of furans (typically 2 to $7 \mathrm{wt}$. \% of bio-oil). These molecules are also typically quantified by $\mathrm{GC} / \mathrm{MS}^{2}$ and are formed from the depolymerization of lignin or its oligomeric products $^{50}$. The compounds not identified by GC/MS are heavy oligomers. The third family is formed by lignin derived oligomers also known as "pyrolytic lignin" which is quantified by cold water precipitation ${ }^{33}$. This fraction is collected in the form of a water insoluble powder at typically between 7 and 24 wt. $\%$ of the oil ${ }^{2}$. The lignin oligomers are formed from lignin depolymerization into a liquid intermediate and are removed by thermal ejection ${ }^{51}$. This fraction has been thoroughly characterized ${ }^{33-35}, 52$. The water soluble fraction contains carbohydrates (mono and oligo anhydrosugars) and other poorly characterized oligomers ${ }^{2,24,45}$. The sugars in this fraction are derived from the depolymerization of cellulose and hemicellulose and can be quantified by the sulfuric acid assay ${ }^{2,44}$. Levoglucosan, cellobiosan and cellotriosan are the main carbohydrates found in pyrolysis oils ${ }^{53}\left(12\right.$ and 17 wt. $\left.\%^{2}\right)$. Studies by ICR-MS and UVFluorescence of the water soluble fractions and the whole pyrolysis oil ${ }^{2,29}$ point to the existence of two other oligomeric fractions soluble in water: pyrolytic humins, and hybrid oligomers (products of carbohydrate and lignin reaction). Standards strategies to separate, quantify and characterize these fractions are lacking². 
Table 1. Main pyrolysis oil compounds identified and quantified by GC/MS (wt. \%) (2, $43^{2}$

\begin{tabular}{|c|l|c|}
\hline No. & Compound & Range \\
\hline \multicolumn{2}{|c|}{ C2-C4 molecules } \\
\hline 1 & Glycolaldehyde & $1.0-13.7$ \\
\hline 2 & Acetic acid & $2.5-8.7$ \\
\hline 3 & Acetol Mono-phenols and mono-furans \\
\hline 5 & Propanoic acid & $2.6-8.6$ \\
\hline \multicolumn{2}{|c|}{$0.2-2.8$} \\
\hline 7 & 2-cyclopenten-1-one & $0.1-0.2$ \\
\hline 8 & Furfural & $0.1-0.6$ \\
\hline 11 & 2(5H)-furanone & $0.1-0.8$ \\
\hline 12 & 3-methyl-1,2-cyclopentanedione & $0.3-0.5$ \\
\hline 13 & Methyl-2(5H)-furanone & $0.0-0.2$ \\
\hline 14 & Phenol & $0.0-0.9$ \\
\hline 15 & Guaiacol & $0.1-0.5$ \\
\hline 20 & Creosol & $0.1-0.5$ \\
\hline 21 & 2,4-xylenol & $0.0-0.0$ \\
\hline 22 & 4-ethylguaiacol & $0.0-0.1$ \\
\hline 23 & Eugenol & $0.1-0.6$ \\
\hline 25 & Catechol & $0.2-0.9$ \\
\hline 26 & Syringol & $0.0-0.4$ \\
\hline 27 & 4-methylcatechol & $0.0-0.5$ \\
\hline 28 & Vanillin & $0.1-1.5$ \\
\hline 32 & Syringylaldehyde & $0.0-0.1$ \\
\hline & & \\
\hline 34 & Levoglucosan & $3.0-6.5$ \\
\hline
\end{tabular}




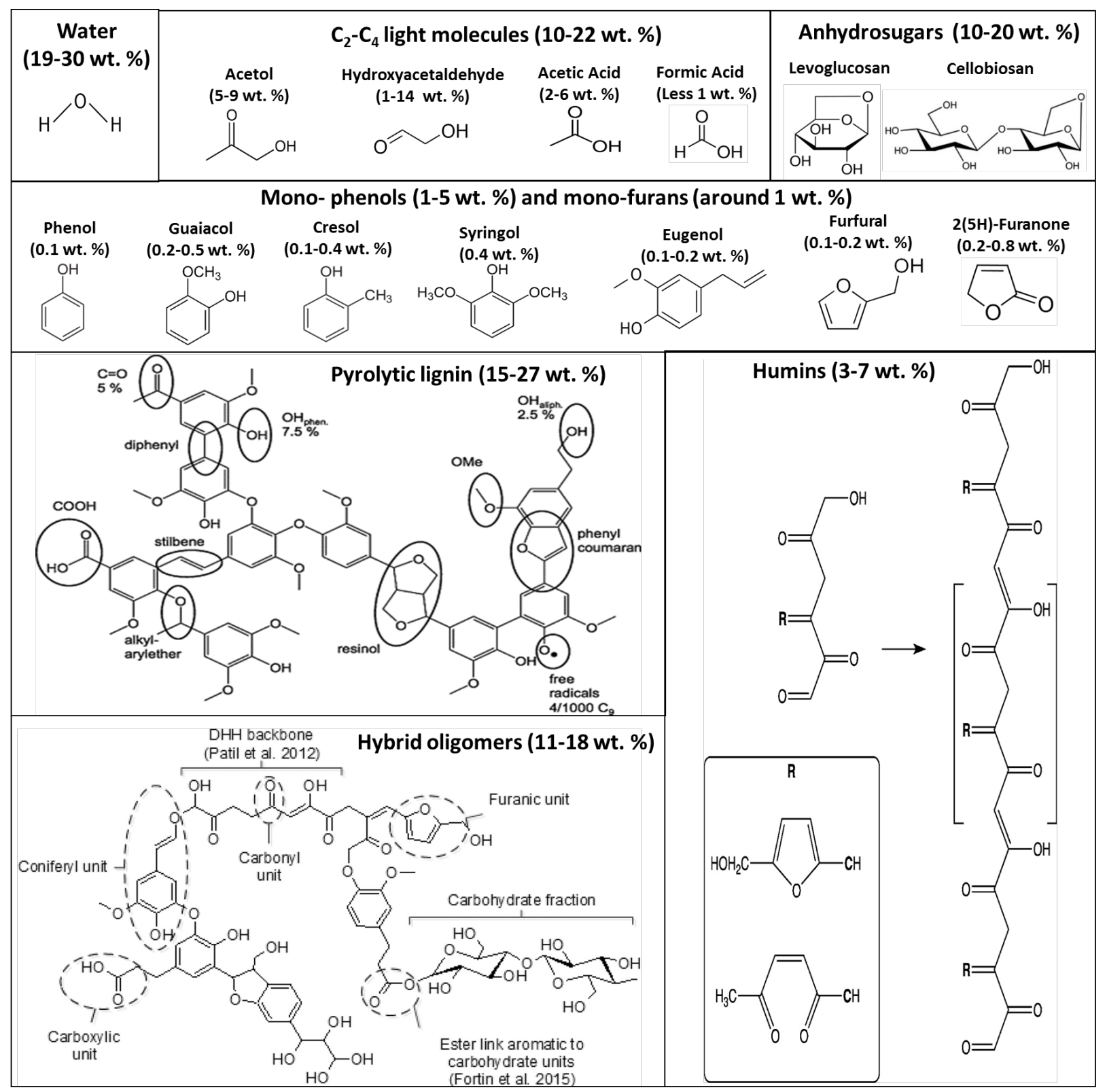

Figure 1. Representative molecules of each of bio-oil fractions

The bio-oil compounds can also be described in terms of functional groups, namely: acids, alcohols, aldehydes, esters, ketones and phenols (see Table 2$)^{2}$. Stankovikj et al. ${ }^{2}$ compared the content of functional groups in the whole oil with the content of these groups estimated from GC/MS and concluded that between 85 and $95 \%$ of the phenols, and 33 to 48 wt. \% of the acid functional groups in pyrolysis oils are in the form or oligomers Although the GC/MS detectable 
compounds only represent $30 \mathrm{wt}$. \% of the whole oil, it accounts for half of the very reactive carbonyl and carboxyl functional groups ${ }^{2}$.

Table 2. Methods for the quantification of functional groups in pyrolysis oils and range of values $^{29,31}$

\begin{tabular}{|l|c|c|}
\hline Functional group & {$[\mathrm{mmol} / \mathrm{g}]$} & Quantification Method \\
\hline Carbonyl & $2.8-5.3$ & Carbonyl titration \\
\hline Carboxylic acids & $0.5-2.6$ & ${ }^{31} \mathrm{P}-\mathrm{NMR}$ \\
\hline Phenolics & $0.9-3.9$ & ${ }^{31} \mathrm{P}-\mathrm{NMR}$ \\
\hline Aliphatic alcohols & $3.3-5.4$ & ${ }^{31} \mathrm{P}-\mathrm{NMR}$ \\
\hline Total Acid number $(\mathrm{mg} \mathrm{KOH} / \mathrm{g})$ & $181-188$ & Potentiometric titration \\
\hline
\end{tabular}

\section{Review of Existing Bio-oil Refinery Concepts}

\subsection{Wood distillation industry}

Figure 2 shows is an overview of the historic hardwood distillation industry from the nineteen and early part of the twenty century. This industry produced charcoal, tars, acetone and wood naphtha ( $\mathrm{C} 1$ to $\mathrm{C} 4$ compounds) mostly from hardwoods. When a single condensation step was used, the liquid naturally separates into a decanted tar (formed mostly from lignin derived compounds) $)^{54}$ and an aqueous phase rich in C1-C4 molecules and dissolved tar (heavy oligomers derived from cellulose and hemicellulose $)^{54}$. Dissolved tar is then obtained via distillation of the aqueous phase (also known as pyrolygneous water). The $\mathrm{C} 2-\mathrm{C} 4$ rich vapors produced in the distillation steps (see Figure 2) were recovered in a limewash vessel as lime acetate and crude wood naphta. The lime acetate was dry-evaporated using drums at temperature up to $180^{\circ} \mathrm{C}$. This acetate was known as gray acetate and contained $80 \mathrm{wt}$ \% calcium acetate ${ }^{55}$. When decomposed with sulfuric acid, the gray acetate produced $85 \%$ acetic acid. Acetone could be obtained by heating the gray acetate to $400-500^{\circ} \mathrm{C}$ and purifying the crude acetone through rectification ${ }^{55}$ (see Figure 2). Crude wood naphtha was separated into methanol, water and other organics in a rectification column. 


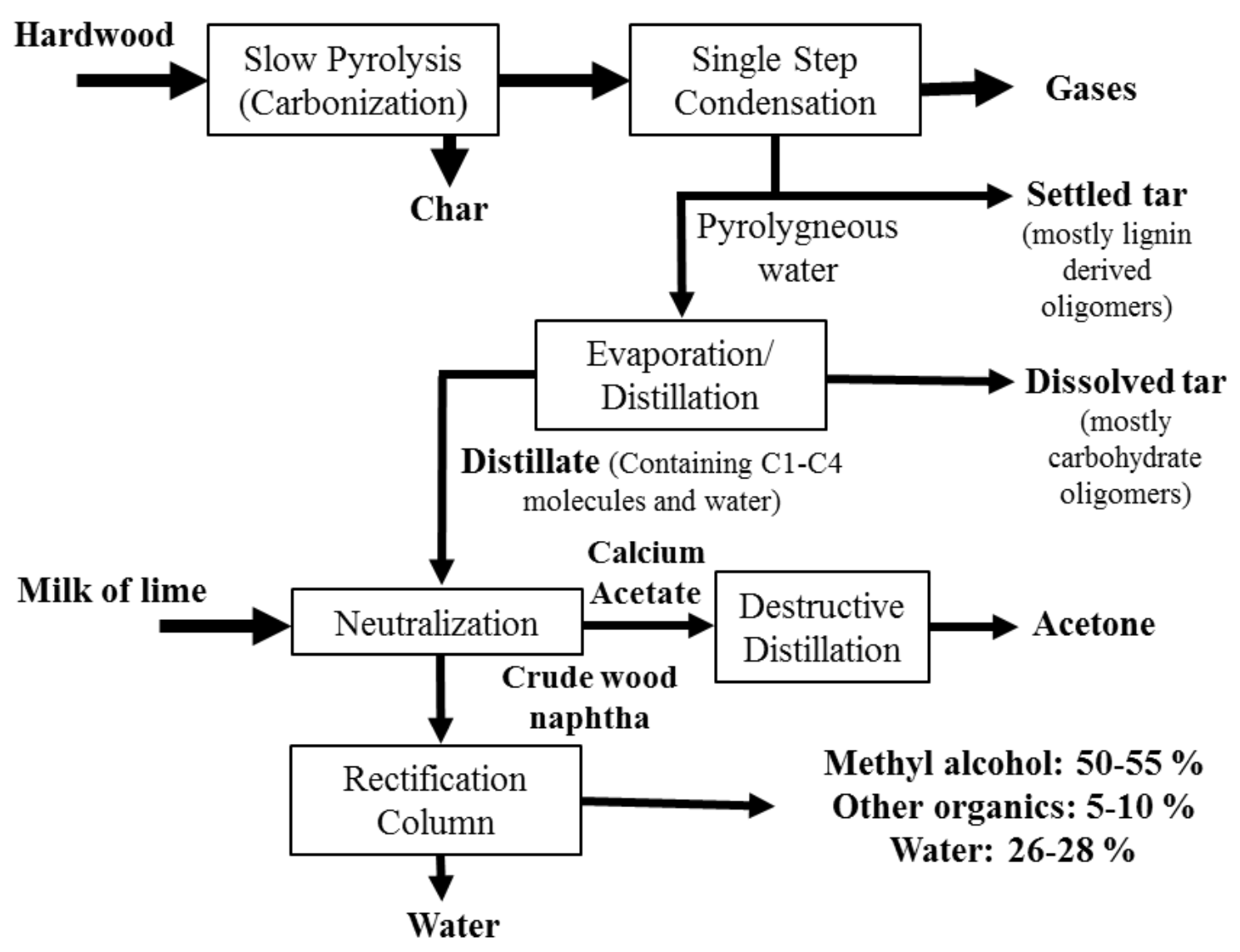

Figure 2. Overview of the old wood distillation industry. The products are in dashed boxes. Adapted from ${ }^{56}$

Acetic acid in the pyrolygneous water could also be recovered by distillation ${ }^{55}$. The first option was a direct method, in which pyroligneous acid was distilled from a weak acid solution and toluene was used to draw off the moisture of the mixture. The second option, slightly more sophisticated, consisted in a two stage process. The solution obtained from the first distillation was mixed with xylene, which formed a low-boiling-point-binary mixture with water. After concentrating acetic acid from the first stage, it undergoes a second distillation with benzene to form a new mixture ${ }^{55}$. Products Chemiques de Clamancy and Lambiotte Brother plant ${ }^{55}$ devised a method in which moisture was eliminated either by distilling an azeotrope formed with butyl acetate or by circulating butyl acetate in a counter-current tar reactor with the wood spirit ${ }^{55}$. 


\subsection{Two steps hydrotreatment}

The production of drop-in fuels from pyrolysis oils has received increasing attention in the last thirty years ${ }^{57,58}$. Elliot ${ }^{59}$, and, Wang et al. ${ }^{60}$, provide a good review of the advances in catalytic hydroprocessing of bio-oils, including the catalysts used on hydrotreating/hydrocracking tests. Early work on bio-oil hydrotreatment was conducted at the Pacific Northwest National Lab (PNNL) using catalysts from petroleum processing (sulfided $\mathrm{NiMo} / \mathrm{Al}_{2} \mathrm{O}_{3}$ and $\mathrm{CoMo} / \mathrm{Al}_{2} \mathrm{O}_{3}$ catalysts) ${ }^{61}$ resulting in a hydrocarbon rich product but incurring high hydrogen consumption [4$6 \mathrm{~kg} \mathrm{H}_{2}$ per $100 \mathrm{~kg}$ bio-oil]. Supported noble metals, such as $\mathrm{Ru}, \mathrm{Pd}, \mathrm{Pt}$, and $\mathrm{Rh}$, have recently been investigated as hydrotreating catalysts ${ }^{60,62}$.

The two-stage method was patented by PNNL ${ }^{63,64}$ (see Figure 3). The first reactor, or the stabilization reactor, is operated at $150-300{ }^{\circ} \mathrm{C}$. Although the goal of this step is to convert carbonyl and carboxyl functional groups into alcohols, other reactions such as decarboxylation $\left(\mathrm{CO}_{2}\right.$ generation), re-polymerization (water production), and hydrotreating also take place ${ }^{65,66}$. Another important goal of stabilization is to convert sugars into sugar alcohols by hydrogenation, to avoid coking during the deoxygenation and hydrocracking in the second step ${ }^{67}$. Stabilization is challenging because an important fraction of the targeted very reactive functional groups is in the form of heavy oligomeric compounds (40 mol. \% of the carboxylic acids, $50 \mathrm{~mol}$. \% of the carbonyl and 90 mol. \% of the phenols are in oligomeric form ${ }^{29}$. Deep hydrodeoxygenation and hydrocracking is performed in a second reactor at harsher conditions of $300-500{ }^{\circ} \mathrm{C}$, and $10-14$ $\mathrm{MPa}^{67}$.

Elliot et al. ${ }^{68,69}$ used a $\mathrm{Pd}$ on carbon $(\mathrm{Pd} / \mathrm{C})$ catalyst at the bench-scale, in a fixed-bed reactor for the hydrotreatment of bio-oils, as a first stabilization step for bio-oil upgrading. The hydrotreatment product was then further processed through hydrodeoxygenation and hydrocracking to achieve final deoxygenation of almost $100 \%$. Wildschut et al. ${ }^{70}$ compared a range of metal catalysts $\left(\mathrm{Ru} / \mathrm{C}, \mathrm{Ru} / \mathrm{TiO}_{2}, \mathrm{Ru} / \mathrm{Al}_{2} \mathrm{O}_{3}, \mathrm{Pt} / \mathrm{C}\right.$ and $\left.\mathrm{Pd} / \mathrm{C}\right)$ with the classic hydrotreatment catalysts (sulfided $\mathrm{NiMo} / \mathrm{Al}_{2} \mathrm{O}_{3}$ and $\mathrm{CoMo} / \mathrm{Al}_{2} \mathrm{O}_{3}$ ), in a batch set-up, at temperatures between $250-350^{\circ} \mathrm{C}$ and pressures in the range of $100-200$ bar. $\mathrm{Ru} / \mathrm{C}$ catalysts showed to be the most promising. The deoxygenation level was up to $90 \mathrm{wt} \%$, decreasing the acidity and water content of the oil, while increasing the high heating value from $20.3 \mathrm{MJ} / \mathrm{kg}$ to 
42.6 MJ/kg. Additional studies involving the use of metal catalysts in bio-oil hydrotreatment can be found elsewhere ${ }^{71-73}$. Another class of catalysts that has been investigated for hydrotreatment of bio-oils are the transition metal phosphides ${ }^{74,75}$. as reviewed elsewhere ${ }^{74,76-79}$.

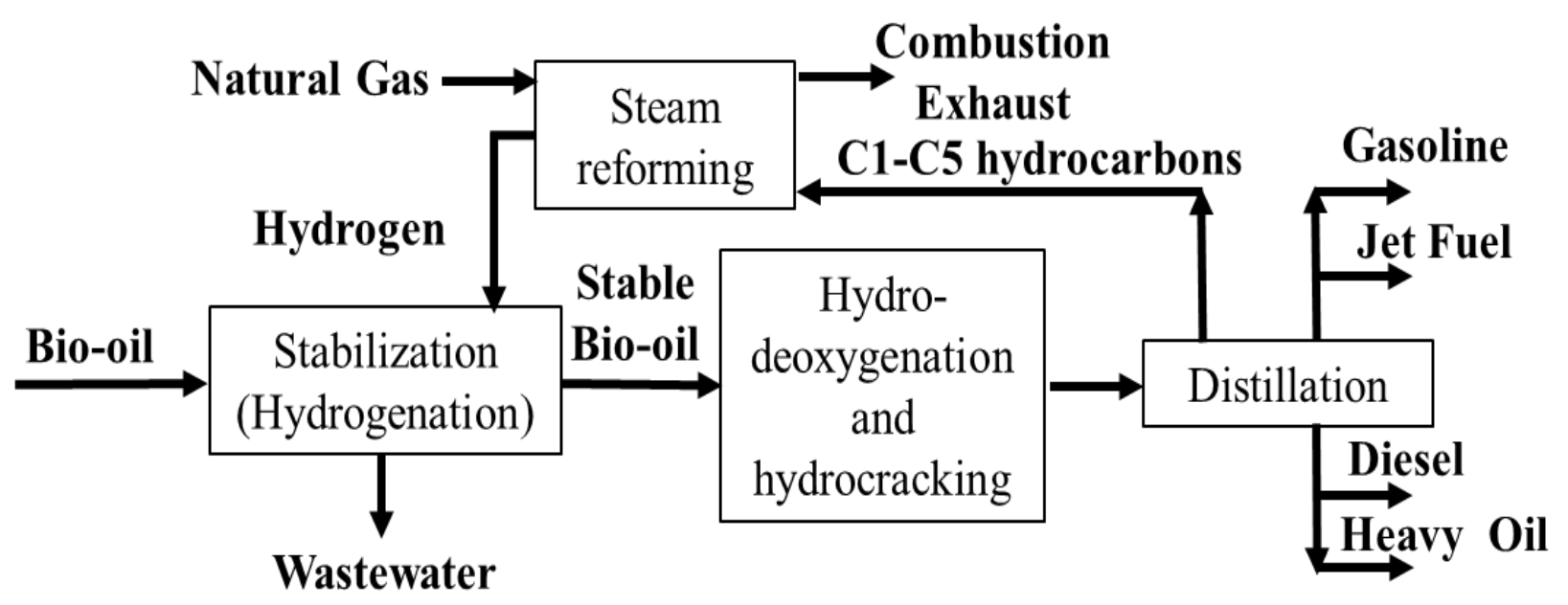

Figure 3. Hydrotreating/hydrocracking of bio-oil process flow ${ }^{80}$

The hydrotreatment of bio-oil consumes 3-5.8 wt. \% of hydrogen, and yields approximately 41 wt. \% of fuels in the naphtha and diesel range. The remaining products include $\mathrm{CO}_{2}$, water and volatile compounds ${ }^{81}$. With this technology 33 wt. \% of this oil can be converted into hydrocarbons ${ }^{80-82}$. Elliott ${ }^{83}$ reported that 121 gallons of hydrocarbons/ton of bone dry wood can be obtained using the hydrotreatment of bio-oil ${ }^{83,84}$.

\subsection{Co-processing of bio-oils with petroleum fractions:}

Another alternative for bio-oil upgrading is the addition of the whole bio-oil, bio-oil fractions or partially upgraded bio-oil to specific petroleum fractions for further processing in conventional refinery units ${ }^{85}$. This strategy is commonly named co-processing or co-refining, and some examples appearing in literature will be discussed.

The level of deoxygenation of the pyrolysis oils for successful co-processing in refining remains unclear. The NREL thermochemical group ${ }^{86}$ recommends that the oxygen content must be reduced to less than $7 \mathrm{wt}$ \% before the oil can be considered stabilized and ready to be co- 
processed in an existing petroleum refinery. The oil is almost completely miscible with petroleum at these oxygen levels. Stabilized oil with higher oxygen content has been shown ${ }^{87}$ to have low acidity, good volatility, and good miscibility. This oil can also be hydrocracked without coking $^{88}$. The hydrodeoxygenated pyrolysis oil was mixed up to $10-20 \mathrm{wt}$. $\%$ with heavy petroleum fractions (i.e. gas oil, vacuum gas oil, VGO spell out) and then co-processed via catalytic cracking in lab-scale reactors using FCC and zeolite-type catalysts ${ }^{89}$, and also in a demonstration FCC refinery unit ${ }^{90}$. In general, the amounts of valuable products attained, such as gasoline, naphtha, light cycle-oil (LCO), light gases, and olefins do not differ substantially from those when only a petroleum fraction is processed. The quantity and quality of biogasoline (and naphtha) produced during co-processing of pre-hydrotreated bio-oils with VGO in lab-scale FCC unit can be optimized as a function of the pyrolytic oil/VGO ratio and the severity of hydrotreatment step. The optimum in gasoline/naphtha quality in terms of octane rating was found by mildly hydrotreating bio-oil $\left(\mathrm{H}_{2}\right.$ consumption $=202 \mathrm{NL}$ (STP) $\mathrm{kg}_{\text {bio-oil }}{ }^{-1}=9 \mathrm{mmol} \mathrm{g}_{\text {bio- }}$ oil $^{-1}$ ) and co-processing hydrotreated-oil/VGO at a $10 / 90$ weight ratio ${ }^{91,92}$. Nevertheless, the production of aromatics (including phenolic compounds) strongly increased ${ }^{89}$, as well as the amount of char and coke formed on the catalyst surface, this leading to the deactivation of the catalys $\mathrm{t}^{88,90}$. In fact, studies of catalytic cracking of hydrocarbon fractions with the addition of model oxygenated compounds representative of the bio-oil composition revealed that their presence leads to the rapid formation of carbonaceous deposits (via oxygenated compounds deoxygenation) onto the zeolitic acid active sites of the FCC catalyst ${ }^{88,91}$. Coking deactivates the catalyst by pore blocking of the zeolitic structure and was found to be difficult to reverse.

Similar behavior has been observed by Corma et al. ${ }^{92}$ when co-feeding a VGO fraction with glycerol and sorbitol to evaluate the effect of these non-conventional organic compounds in the catalytic cracking of petroleum feedstock at lab-scale by using different catalysts (i.e. FCC catalysts, mesoporous $\mathrm{Al}_{2} \mathrm{O}_{3}$ and zeolites) $)^{92}$. They concluded that oxygen is removed from these compounds as $\mathrm{H}_{2} \mathrm{O}, \mathrm{CO}$ and $\mathrm{CO}_{2}$, mainly producing olefins, paraffins and coke, while aromatics are formed in high yields $(\approx 20 \mathrm{~mol} \%)$ via Diels-Alder and condensation reactions of olefins and dehydrated species. More importantly, glycerol can be co-fed with VGO fraction without significantly alteration of the products distribution, resulting in final selectivities better than those calculated by considering a simple additive effect do. Of course, the co-processing of bio- 
oil + VGO mixtures is more complicated than the co-feeding of only one component, such as glycerol.

Eliminating or replacing the previous hydrodeoxygenation step of bio-oils before co-refining in FCC units by a less energy demanding upgrading step is also another alternative. In this sense, Thegarid et al. ${ }^{95}$ have compared the co-processing of both CPO (a bio-oil produced by catalytic pyrolysis of biomass) and Hydrodeoxygenated oil (HDO) with a VGO fraction in a lab-scale FCC unit, concluding that better results in terms of products distribution and final fuel quality favored the co-processing of HDO-oil with the VGO fraction. The observed differences might be overcome with the enhancement of the $\mathrm{CPO}$ quality by further catalyst development in the pyrolysis step ${ }^{95}$.

Additionally, partially hydrodeoxygenated liquids obtained from both oil fraction (OFWA) and aqueous fraction (AFWA) of pyrolytic oil have been co-processed with Long Residue petroleum fraction in a lab-scale catalytic cracking unit with acceptable results, similar to those attained with the Long Residue alone. The same hydrodeoxygenated liquids have also been co-processed with SRGO fraction in a HDS lab-scale unit, resulting in a competition between HDS and HDO reactions during process without permanent catalyst deactivation ${ }^{72}$.

Pinheiro et al. ${ }^{96}$ have studied the influence of some selected oxygenated compounds representative of the bio-oils composition in the hydrotreating (simultaneous HDO, HDS and $\mathrm{HDN}$ ) of a straight-run gas oil (SRGO) fraction over a $\mathrm{CoMo} / \gamma-\mathrm{Al}_{2} \mathrm{O}_{3}$ catalyst under industrial operational conditions. They have observed that the presence of carboxylic group containing compounds strongly inhibit HDS and HDN catalytic functions ${ }^{96}$. Similar behavior was observed when guaiacol was co-processed in an HDS unit together with a straight-run gas oil (SRGO) fraction $^{97}$.

\section{Major hurdles for bio-oil refining}

Although, several fast pyrolysis plants were built and are currently in operation around the world, the lack of bio-oil refining capabilities does not allow the deployment of this technology ${ }^{2}$. The high concentration of oxygen in bio-oil - up to $40 \mathrm{wt} . \%^{98}$ - associated to the reactivity of these compounds, affects the thermal stability of these oils during storage, handling and 
upgrading ${ }^{60,65,99}$. Because of the presence of water and the large number of molecules covering a wide range of molecular weights and functionalities will require more separation steps than conventional petroleum, bio-oil refining costs are likely to be higher than for competing sources of organics (molasses and petroleum) ${ }^{100}$. To ensure economic competitiveness, bio-oil price need to be a fraction of those of cheap sugar sources (molasses typically: $\$ 300-400 \mathrm{t}^{-1}$ ) and petroleum (typically: $\$ 206-687 \mathrm{t}^{-1}$ ). According to the literature, bio-oil production cost varies between $\$ 98$ and $860 \mathrm{t}^{-1}\left(\$ 0.41-3.61 \text { gallons }^{-1}\right)^{67,101-109}$. Thus, efforts are needed to keep bio-oil production costs below $\$ 150 \mathrm{t}^{-1}$.

The published techno-economic analyses on the two step hydrotreatment biorefinery concept estimated minimum selling prices of resulting transportation fuels between $\$ 694$ and $1455 \mathrm{t}^{-1}$ (\$ 2.1 and 4.4 gallon $\left.^{-1}\right)^{67,80,82,110-113}$. In order to explore how easy will it be to further reduce production costs for the two step bio-oil refinery concept we used the criteria recommended by Lange et al. ${ }^{100}$. In the chemical industry typical conversion costs are between $\$ 100-300 \mathrm{tfeed}^{-1}{ }^{100}$. Conversion costs depend on complexity and scale and correlate well with the energy transfer duty applied and the number of separation segments ${ }^{100,114}$. A simple calculation supposing an optimistic bio-oil purchasing cost of $150 \$ \mathrm{t}^{-1}$, an optimistic processing costs of $200 \mathrm{tfeed}^{-1} 100$ and a very optimistic fuel product yield of 33 wt. \%, suggest that a refinery concept with these characteristics will be only viable if the resulting products can be commercialized at least at 1 $060 \mathrm{t}^{-1}$ (within the range reported in the literature) ${ }^{67,80,82,113}$. This cost estimation suggest that the two step bio-refinery concept proposed will result in products competitive with chemicals and solvents ( $\$ 1000$ and $2000 \mathrm{t}^{-1}$ ) but will have difficulties to be competitive with transportation fuels (gasoline market price: $\left.\$ 700-800 \mathrm{t}^{-1}\right)^{100}$.

There are fundamental technical challenges to improve fuel yield and reduce production costs in the two step hydrotreatment concept. Bio-oil deoxygenation is fundamentally an emerging, poorly known and very expensive unit operation ${ }^{100}$. In this step, the oxygen purchased as part of the bio-oil is converted into water with high hydrogen and energy consumption ${ }^{100}$. If a fully deoxygenated molecule is the main targeted product (let's suppose benzene), to achieve a $33 \mathrm{wt}$. $\%$ bio-oil conversion (Bio-oil C content: 43 wt. \%), overall carbon conversion efficiencies need to be higher than $70 \%$. Increasing carbon efficiency will require the use of very selective hydrogenation, cracking and hydro-deoxygenation catalysts ${ }^{100}$ as well as very efficient 
separation processes. High hydrogen consumption $\left(5.8 \mathrm{~g}\right.$ of $\mathrm{H}_{2} / 100 \mathrm{~g}$ of oil $=2.9 \mathrm{mmol} \mathrm{H} / \mathrm{g}_{\text {bio- }}$ oil $^{82}$, the lack of high value products, the resulting fuel very rich in aromatics, multiple operational challenges associated with the difficulties to hydrogenate and deoxygenate oligomeric and very reactive oxygenated molecules resulting in frequent catalyst deactivation, coke formation and reactors plugging are other intrinsic weaknesses of this technology ${ }^{65}$. Our analysis clearly shows that the two step hydrotreatment bio-oil refinery concept only targeting the production of hydrocarbon transportation fuels has a very narrow and challenging path to be economically viable.

Slightly higher prices than drop in fuels $\left(\$ 700-800 \mathrm{t}^{-1}\right)$ can be obtained for light olefins (ethylene, propylene, butadiene) $\left(\$ 900-1,500 \mathrm{t}^{-1}\right)$ used for plastic production. Some small oxygenated molecules (methanol, ethanol, formic acid and acetic acid) have prices below transportation fuels $\left(\$ 400-770 \mathrm{t}^{-1}\right)$ and markets an order of magnitude smaller however, they are highly oxygenated molecules that at least in theory could be obtained in high yields from these oils. Acetic acid can be produced by biomass pyrolysis ${ }^{16}$ but the bulk (65\%) is produced by the carbonylation of methanol. The largest acetic acid uses are in the form of vinyl acetate $(4.1106 \mathrm{t}$ $\left.\mathrm{y}^{-1}\right)$, ethyl acetate $\left(1\right.$ million $\left.\mathrm{t}^{-1}\right)$, peracetic acid $\left(18,000 \mathrm{t}^{-1}\right)$, acetic anhydride (1 to $\left.2106 \mathrm{t} \mathrm{y}^{-1}\right)$, chloroacetic acid $\left(370,000 \mathrm{ty}^{-1}\right)$, and acetate salts ${ }^{115}$. The fact that the market price of acetic acid $\left(\$ 0.6 \mathrm{~kg}^{-1}, 2009\right.$ level$)$ is significantly higher than pyrolysis oil price estimates $\left(\$ 0.15-0.38 \mathrm{~kg}^{-}\right.$ $\left.{ }^{1}\right)$ means that the separation and commercialization of acetic acid likely will continue to increase the economic attractiveness of the pyrolysis oil value chain ${ }^{15}$.

Other small oxygenated molecules (acetone, butanol, ethylene glycol, propylene glycol) are commercialized at higher prices $\left(\$ 1,100-1,800 t^{-1}\right)$. Like in the case of the small molecules, the polymers can also be classified into relatively cheap materials (market price less than $\$ 1,000 \mathrm{t}^{-1}$ ) (polyester, polyurethane) and those with market price over $\$ 1,000 \mathrm{t}^{-1}$ (polyamide, polypropylene, polyether-polyols and hot melt adhesive). Carbon fiber is a very interesting product due to its high market value (more than $\$ 50,000 \mathrm{t}^{-1}$ ). Agriculture chemicals (insecticides, fungicides, insect-fungicides, herbicides, redentocides, plant growth regulators, repellents, thermicides) are also interesting products have a global market of 215 billion dollars ${ }^{116}$ with great potential for pyrolysis products. For example, glyphosate is commercialized today between $\$ 4,000$ and $\$ 6,000 \mathrm{t}^{-1}$. Today raw wood vinegar (aqueous phase from pyrolysis 
oils) is commercialized in Asia at $\$ 600 \mathrm{t}^{-1}$ for agricultural applications (rosette or green mosaic in wheat, nematode in sweet potato, tobacco mildew in leafy vegetables). A careful analysis of this information and the need to achieve relatively high conversion yields from an oxygenated oil like bio-oil, suggest that a balanced production of materials, oxygenated small molecules and small hydrocarbons is critical to develop viable bio-oil refineries. The production of macromolecules and polymers from bio-oil fractions should be our priority due to its higher price, but we should be aware of potential market saturation. Our second priority should be the development of small oxygenated molecules to be used as solvents, chemicals or fuel additives. Hydrocarbons for fuel application should only be produced from fractions for which more valuable compounds have saturated their existing markets.

\section{Bio-oil Fractionation Strategies}

An overview on the importance of separation technologies for the development of bio-oil refineries has been published elsewhere ${ }^{117}$. Diluted aqueous solutions require typically a preconcentration of fractionation before purification. High dilution often results in large reaction processing equipment and expensive operations ${ }^{117}$. The presence of water, small quantities of inorganic compounds and reactive oxygenated compounds forming complex matrices, low thermal stability, azeotropes and low $\mathrm{pH}$ are main challenges for the development of bio-oil refineries ${ }^{117}$. In this section we will review processes that result in intermediate enriched fraction critical to reduce overall separation costs in bio-oil refineries. Figure 4 summarizes the stages used in the literature for bio-oil fractionation. 


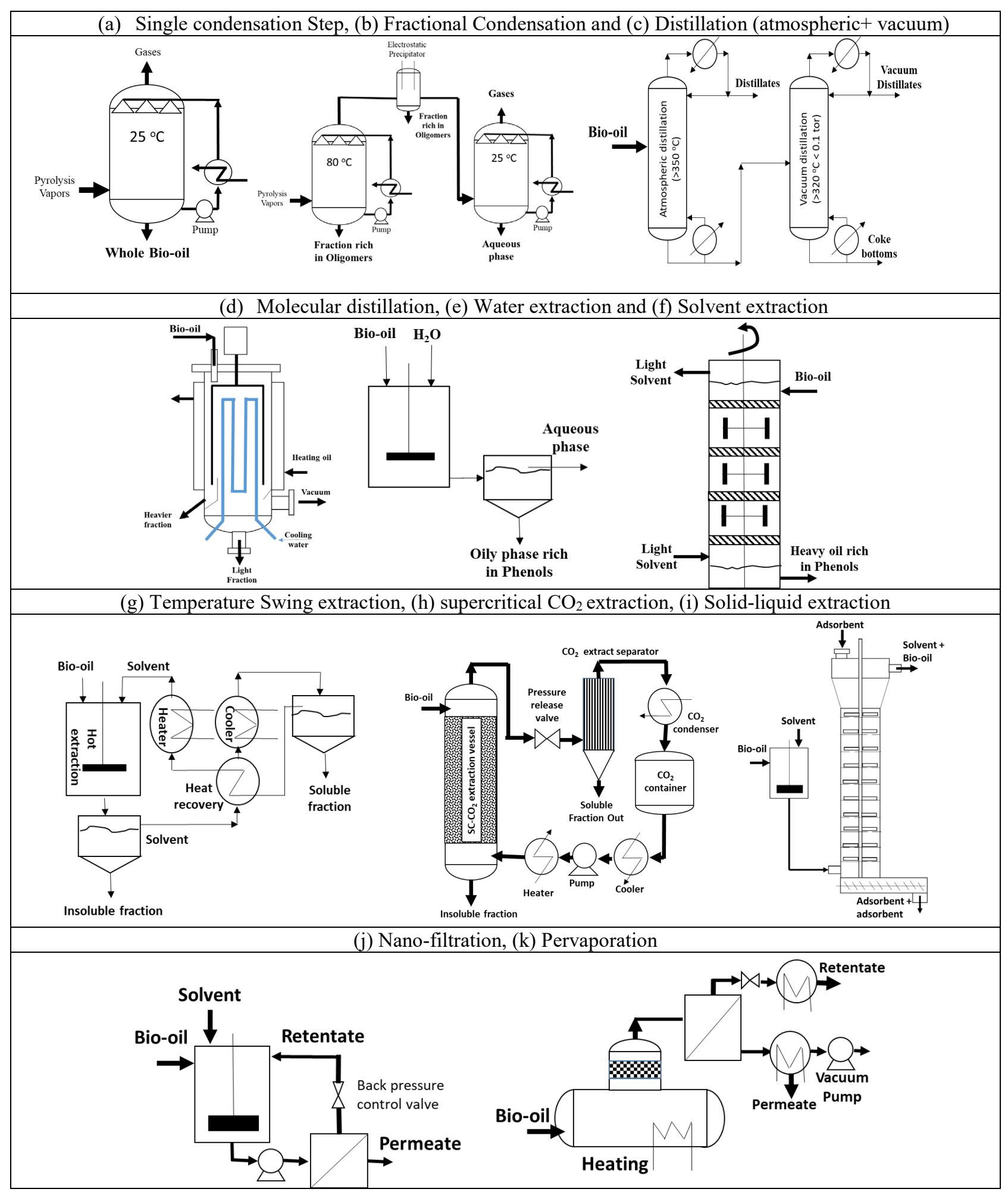

Figure 4. Strategies reported in the literature for bio-oil primary fractionation 


\subsection{Fractional Condensation Systems}

The easiest way to separate bio-oil into light and heavy fractions is using a series of fractional condensation systems operated with decreasing temperature gradient (condensers upstream operating at higher temperatures ${ }^{118}$. Fractional condensation systems were reviewed elsewhere ${ }^{12}$. It is important to highlight that while most of the light fractions (water, C1-C4, mono-phenols and mono-sugars) are in vapor phase, the heavy oligomeric fractions are in the form of aerosols ${ }^{51}$. The temperature, residence time, condensation surfaces and the addition of an electrostatic precipitator, among other factors have a high influence on the final composition of the fractional condensation systems oil fractions ${ }^{19-134}$.

Westerhof et al. ${ }^{135}$ studied the effect of the reactor temperature and the temperature of the first condenser (between 25 and $70{ }^{\circ} \mathrm{C}$ ) on the yield and composition of the collected bio-oil. With this system it is possible to separate the bio-oil in an aqueous phase with high content of acetic acid, hydroxyacetaldehyde and acetol, and a heavy oil rich in heavy oligomeric products. The authors ${ }^{134}$ developed a mathematical model based on phase equilibrium to describe the yield of products and their composition. The model developed by Westerhof et al. ${ }^{134}$ considered bio-oils as a mixture of 13 groups representing each of them by a compounds with a well-known vapor pressure (see Table 3). By carefully controlling operational conditions products with up to $10 \mathrm{wt}$. $\%$ acetic acid and 8 wt. \% acetol were obtained ${ }^{135}$. Fractional condensation systems with electrostatic precipitators before the cold stage allows the collection of the heavy fractions in the form of aerosols ${ }^{123,124,126,136}$. 
Table 3. Description of Bio-oil chemical composition in equilibrium model for fractional condenser (Modified from ${ }^{134}$ )

\begin{tabular}{|c|c|c|c|c|}
\hline Group & $\begin{array}{l}\text { Normal } \\
\text { Boiling } \\
\text { point }(\mathrm{K})\end{array}$ & Components & $\begin{array}{l}\text { Representative } \\
\text { component }\end{array}$ & $\begin{array}{l}\text { Normal } \\
\text { Boiling } \\
\text { point } \\
\text { (K) }\end{array}$ \\
\hline \multicolumn{5}{|c|}{ C1-C4 molecules } \\
\hline 1 & $250-300$ & Formaldehyde, acetaldehyde & Formaldehyde & 253.9 \\
\hline 2 & $300-330$ & Propionaldehyde, glycolic acid, glyoxal, acetone & Propionaldehdye & 322 \\
\hline 3 & $330-360$ & $\begin{array}{l}\text { Methanol, 2-oxobutanoic acid, ethanol, MEK, 2-propanol, (5H)- } \\
\text { furan-2-one }\end{array}$ & Ethanol & 351.6 \\
\hline 4 & $360-390$ & Formic acid, hydroxyacetaldehyde, 5-hydroxymethylfurfural & Formic acid & 373.9 \\
\hline 5 & $390-420$ & $\begin{array}{l}\text { Acetic acid, butanol, lactic acid, 4-propylguaiacol, propionic } \\
\text { acid, acrylic acid, acetol }\end{array}$ & Propionic acid & 414.2 \\
\hline \multicolumn{5}{|c|}{ Mono-phenols and Furans } \\
\hline 1 & $420-450$ & $\begin{array}{l}\text { Isobutyric acid, 2-hydroxy-2-cyclopentanone-1-one, 2-hydroxy- } \\
\text { 1-methyl-cyclopentene-3-one, 1-hydroxy-2-butanone, furfural, } \\
\text { methacrylic acid, n-butyric acid, coniferylaldehyde }\end{array}$ & n-butyric acid & 436 \\
\hline 2 & $450-500$ & $\begin{array}{c}\text { Phenol, crotonic acid, valeric acid, 3-hydroxypropanoic acid, o- } \\
\text { cresol, tiglic acid, 4-methylpentanoic acid, p-cresol, m-cresol, } \\
\text { hexanoic acid, guaiacol, 4-hydroxybenzaldehyde, 4-methyl } \\
\text { guaiacol, vinylguaiacol }\end{array}$ & p-cresol & 475 \\
\hline 3 & $500-550$ & $\begin{array}{c}\text { 4-ethylguaiacol, 1,2-benzendiol, levulic acid, benzaoic acid, } \\
\text { eugenol, syringol, vanillin, isoeugenol }\end{array}$ & Eugenol & 526 \\
\hline \multicolumn{5}{|c|}{ Sugars } \\
\hline 1 & $\infty$ & Levoglucosan, glucose, xylose, cellobiosan, hydroquinone, & Hydroquinone & 558 \\
\hline 2 & $\infty$ & Other sugars & - & $\infty$ \\
\hline \multicolumn{5}{|c|}{ Lignin derived products } \\
\hline 1 & $\infty$ & Low Molecular Weight Pyrolytic Lignin & - & $\infty$ \\
\hline 2 & $\infty$ & High Molecular Weight Pyrolytic Lignin & - & $\infty$ \\
\hline \multicolumn{5}{|c|}{ Extractives } \\
\hline 1 & $\infty$ & Some compounds identified but not quantitative data on content & - & $\infty$ \\
\hline
\end{tabular}

\subsection{Conventional distillation}

Conventional distillation typically accounts for atmospheric, vacuum and flash distillation ${ }^{137}$.

Bio-oil atmospheric and vacuum distillation is extensively used and well described in the literature $^{138-145}$ (see summary of bio-oil distillation studies in Table 4). The results reported for bio-oil direct distillation are not satisfactory due to bio-oil poor thermal stability ${ }^{117,147}$. 
Table 4. Summary of bio-oil conventional distillation studies

\begin{tabular}{|c|c|c|c|c|c|}
\hline System used & Bio-oil source & Pressures & Temp. range & Observations & Ref \\
\hline $\begin{array}{l}\text { Lab. batch } \\
\text { distillation }\end{array}$ & Vacuum pyrol. of softwood & Atm. & $80-140^{\circ} \mathrm{C}$ & Distillate: 16.5 wt. $\%$. & 146 \\
\hline $\begin{array}{l}\text { Lab. batch } \\
\text { distillation }\end{array}$ & $\begin{array}{l}\text { Vacuum pyrol. sugarcane } \\
\text { bagasse }\end{array}$ & $\begin{array}{l}\text { Atm. and } \\
\text { vacuum } \\
(15 \mathrm{kPa} \\
\text { abs. })\end{array}$ & Up to $140^{\circ} \mathrm{C}$ & $\begin{array}{l}\text { Yield of water: } 17 \text { wt. } \% \text {, yield of } \\
\text { organics: } 13 \text { wt. } \% \text {. Very viscous } \\
\text { solid residue. }\end{array}$ & 138 \\
\hline $\begin{array}{l}\text { Reduced } \\
\text { pressure } \\
\text { distillation } \\
\end{array}$ & Fast pyrolysis of rice husk & $\begin{array}{l}15 \\
\mathrm{mmHg}\end{array}$ & $80^{\circ} \mathrm{C}$ & $\begin{array}{l}\text { The yield of distilled bio-oil was } \\
61 \text { wt. } \%\end{array}$ & 145 \\
\hline $\begin{array}{l}\text { Fractional } \\
\text { distillation }\end{array}$ & Pyrolysis of corn stover & $\begin{array}{l}\text { Atm. and } \\
\text { reduced } \\
\text { (approx. } \\
500 \\
\text { mbar) }\end{array}$ & $\begin{array}{l}\text { Up to } 250^{\circ} \mathrm{C} \\
\text { (atm. pressure) } \\
\text { and up to } \\
230^{\circ} \mathrm{C} \text { (red. } \\
\text { pressure) }\end{array}$ & $\begin{array}{l}\text { Atm.pressure: total recovery of } \\
84 \% \text {. Organic fraction yield: } 65 \% \text {. } \\
\text { Vacuum distillation recovery: } \\
\text { approx. } 73 \% \text {, with an organic } \\
\text { fraction yield of } 57.1 \%\end{array}$ & 140 \\
\hline $\begin{array}{l}\text { Atmospheric } \\
\text { distillation } \\
\text { and co- } \\
\text { pyrolysis } \\
\text { process }\end{array}$ & Pyrol. rice husk & Atm. & Up to $248^{\circ} \mathrm{C}$ & $\begin{array}{l}\text { The distillate accounted for } 51.86 \\
\text { wt. } \% \text { of the raw bio-oil }\end{array}$ & 148 \\
\hline $\begin{array}{l}\text { Fractional } \\
\text { distillation }\end{array}$ & $\begin{array}{l}\text { Tail-gas reactive pyrolysis } \\
\text { (TGRP) and regular } \\
\text { pyrolysis (switchgrass, } \\
\text { horse manure, and } \\
\text { Eucalyptus benthamii) }\end{array}$ & $\begin{array}{l}\text { Atm. and } \\
\text { vacuum }\end{array}$ & Up to $350^{\circ} \mathrm{C}$ & $\begin{array}{l}\text { Overall yield: } 38.9 \text { wt. \% with } \\
\text { regular pyrol. oil. Yield: up to } 56.3 \\
\% \text { using TGRP bio-oil }\end{array}$ & 142 \\
\hline $\begin{array}{l}\text { Fractionatin } \\
\mathrm{g} \text { column or } \\
\text { a short-path } \\
\text { distilling } \\
\text { head }\end{array}$ & $\begin{array}{l}\text { TGRP and regular } \\
\text { pyrolysis of switchgrass } \\
\text { and horse manure }\end{array}$ & $\begin{array}{l}\text { Atm. and } \\
\text { vacuum }\end{array}$ & Up to $350^{\circ} \mathrm{C}$ & $\begin{array}{l}\text { The yield of pyrolyzate of TGRP- } \\
\text { based bottoms was of } 20-50 \%\end{array}$ & 143 \\
\hline $\begin{array}{l}\text { Fractionatin } \\
\mathrm{g} \text { column or } \\
\text { a short-path } \\
\text { distilling } \\
\text { head, with } \\
\text { devolatilizati } \\
\text { on and } \\
\text { calcination }\end{array}$ & $\begin{array}{l}\text { Fast pyrol. of switchgrass, } \\
\text { eucalyptus and guayule } \\
\text { bagasse }\end{array}$ & $\begin{array}{l}\text { Atm. and } \\
\text { vacuum }\end{array}$ & Up to $350^{\circ} \mathrm{C}$ & $\begin{array}{l}\text { Yield of devolatilized bottoms: } 50- \\
65 \% \text {. Yield of calcination was of } \\
85-87 \% \text {. }\end{array}$ & 149 \\
\hline $\begin{array}{l}\text { Atm. Dist., } \\
\text { vac. dist., } \\
\text { calcination } \\
\text { and/or devol. } \\
\text { of the dist. } \\
\text { Bottoms }\end{array}$ & $\begin{array}{l}\text { Fast pyrol. of switchgrass, } \\
\text { eucalyptus and guayule } \\
\text { bagasse }\end{array}$ & $\begin{array}{l}\text { Atm. } \\
\text { dist: } 0.9- \\
1 \text { atm. } \\
\text { Vac. dist: } \\
0.02 \quad- \\
0.13 \text { atm. }\end{array}$ & $\begin{array}{l}\text { Atm. Dist.: } \\
50^{\circ} \mathrm{C} \text { to } \\
400^{\circ} \mathrm{C} \text {. } \\
\text { Vac.dist: } 100- \\
400^{\circ} \mathrm{C} \text {. Devol: } \\
400-1000^{\circ} \mathrm{C} \text {. } \\
\text { Calcination: } \\
1100-1400^{\circ} \mathrm{C} \text {. }\end{array}$ & $\begin{array}{l}\text { Yields of devolatilized bottoms: } \\
50-65 \% \text {. Yield of calcination: } 85- \\
87 \% \text {. }\end{array}$ & 150 \\
\hline
\end{tabular}




\subsection{Molecular distillation:}

Molecular distillation is a process in which the bio-oil is heated under high vacuum in a system in which the distance between the evaporation and the condensation surface is such that the molecules that scape the evaporation surface reach the condensation surface without interacting with other molecules ${ }^{137}$. This method is recommended for the separation of thermally unstable materials ${ }^{137}$. A considerable number of patents and peer reviewed papers on molecular distillation were found in the literature ${ }^{137,151-159}$. Table 5 summarizes the outcome of these papers.

Table 5. Summary of bio-oil molecular distillation studies

\begin{tabular}{|c|c|c|c|c|c|}
\hline System used & Bio-oil source & Pressures & $\begin{array}{l}\text { Temperature } \\
\text { range }\left({ }^{\circ} \mathrm{C}\right)\end{array}$ & Observations & Ref. \\
\hline KDL5: UIC Corp. & $\begin{array}{l}\text { Fast pyr. of } \\
\text { Mongolian Scotch } \\
\text { pine }\end{array}$ & $60 \mathrm{~Pa}$ & $\begin{array}{l}70, \quad 100 \text { and } \\
130^{\circ} \mathrm{C}\end{array}$ & Yield: 83 wt. $\%$ of distillate. & 137 \\
\hline $\begin{array}{l}\text { KDL5: UIC Corp. } \\
\text { Bio-oil pretreated } \\
\text { by vacuum } \\
\text { distillation }\end{array}$ & Fast pyr. & $340-1600 \mathrm{~Pa}$ & $80^{\circ} \mathrm{C}$ & Yield: 43 wt.\%. of distillate & 151 \\
\hline KDL5: UIC Corp. & $\begin{array}{lr}\text { Fast pyr. } & \text { of } \\
\text { Mongolian pine } \\
\text { sawdust }\end{array}$ & $100 \mathrm{~Pa}$ & $80^{\circ} \mathrm{C}$ & $\begin{array}{l}\text { Yields: } 50,7 \text { and } 40 \text { wt. } \% \text { for } \\
\text { light, middle and heavy } \\
\text { fractions. }\end{array}$ & 160 \\
\hline KDL5: UIC Corp. & $\begin{array}{l}\text { Fast pyr. of pine } \\
\text { sawdust }\end{array}$ & $340-1600 \mathrm{~Pa}$ & $80^{\circ} \mathrm{C}$ & Yield: 57 wt. $\%$ of distillate & $\begin{array}{l}161, \\
162\end{array}$ \\
\hline KDL5: UIC Corp. & $\begin{array}{l}\text { Pyrolysis of pine } \\
\text { biomass }\end{array}$ & $60 \mathrm{~Pa}$ & $50^{\circ} \mathrm{C}$ & Yield: 97 wt. \%. Of distillate & 163 \\
\hline KDL-5 & $\begin{array}{l}\text { Fast pyrolysis of } \\
\text { rice husk }\end{array}$ & $\begin{array}{l}1000 \mathrm{~Pa} . \\
\text { Co-cracking } \\
\text { of distilled } \\
\text { fraction (DF) } \\
\text { and Ethanol: } \\
0.1-3 \mathrm{MPa} \\
\end{array}$ & $\begin{array}{l}90^{\circ} \mathrm{C} \text {. } \\
\text { Co-cracking of } \\
\text { the DF and } \\
\text { Ethanol: } 340- \\
430^{\circ} \mathrm{C}\end{array}$ & $\begin{array}{l}\text { The crude-distilled fraction } \\
\text { (CDF) yield was } 55 \text { wt. } \% \text {. } \\
\text { The total liquid yield varied } \\
\text { from } 56 \text { wt. } \% \text { to } 78 \text { wt. \%, } \\
\text { depending on the co-cracking } \\
\text { conditions. }\end{array}$ & 163 \\
\hline $\begin{array}{l}\text { KDL5 from UIC } \\
\text { Corp. }\end{array}$ & $\begin{array}{l}\text { Fast pyrolysis of } \\
\text { lauan sawdust }\end{array}$ & $120 \mathrm{~Pa}$ & $70^{\circ} \mathrm{C}$ & $\begin{array}{l}\text { Yield of heavy fraction: } 49.6 \\
\text { wt. } \% \text {. }\end{array}$ & 164 \\
\hline $\begin{array}{l}\text { Short Path } \\
\text { Evaporators at two } \\
\text { different scales - } \\
\text { bench top scale } \\
\text { and pilot plant } \\
\text { scale }\end{array}$ & $\begin{array}{l}\text { Catalytic Pyr. of } \\
\text { southern yellow } \\
\text { pine wood chips }\end{array}$ & $\begin{array}{l}\text { 1st pass: } 0.40 \\
\text { atm, } \quad 2 \mathrm{nd} \\
\text { pass: } 0.26 \\
\text { torr } 3 \text { rd pass: } \\
0.001 \mathrm{~atm} .\end{array}$ & $\begin{array}{l}\text { 1st } r \text { pass: } \\
50^{\circ} \mathrm{C}, \quad 2 \mathrm{nd} \\
\text { pass: } 100^{\circ} \mathrm{C}, \\
3 \mathrm{rd} \text { pass at } \\
160^{\circ} \mathrm{C}\end{array}$ & The overall yield: $55-92$ wt. $\%$. & 159 \\
\hline- & $\begin{array}{l}\text { Catalytic Pyr. of } \\
\text { biomass. }\end{array}$ & - & $\begin{array}{l}\text { Ex.1: } \text { Up to } \\
75^{\circ} \mathrm{C} \\
\text { Ex.2: Up to } \\
120^{\circ} \mathrm{C}\end{array}$ & $\begin{array}{l}\text { Ex. 1: Yields of light and } \\
\text { heavy: } 12 \text { and } 83 \text { wt. \%, } \\
\text { respectively. Ex 2: Yields of } \\
\text { light and heavy: } 14 \text { and } 38 \text { wt. } \\
\% \text {, respectively. }\end{array}$ & 154 \\
\hline
\end{tabular}




\subsection{Reactive distillation and condensation}

Some authors ${ }^{119,139,142,165}$ have also studied upgraded strategies in which chemical reactions are conducted while the bio-oil is condensed or distilled. These strategies are summarized in table 6 .

Table 6. Summary of bio-oil reactive distillation and condensation

\begin{tabular}{|c|c|c|c|c|}
\hline System used & Bio-oil source & Operation conditions & Observations & Ref. \\
\hline $\begin{array}{l}\text { Reaction } \\
\text { column with } \\
\text { diameter of } 24 \\
\text { mm and height: } \\
800 \mathrm{~mm}\end{array}$ & $\begin{array}{l}\text { Fast pyr. of rice } \\
\text { husk }\end{array}$ & $\begin{array}{lll}\text { Acid catalysts } & \left(\mathrm{SO}_{4}{ }^{2-}\right. \\
\left.\mathrm{M}_{\mathrm{x}} \mathrm{O}_{\mathrm{y}}\right) . & \text { Temperature: } & 47-78 \\
{ }^{\circ} \mathrm{C} . & \end{array}$ & $\begin{array}{l}\text { Important reduction in density and } \\
\text { acidity and increase in calorific value } \\
\text { and thermal stability. Esters were } \\
\text { formed }\end{array}$ & 165 \\
\hline $\begin{array}{l}\text { A distillation } \\
\text { bottle }\end{array}$ & $\begin{array}{l}\text { Slow pyr. of } \\
\text { sawdust pellets } \\
\text { and fast pyr. of } \\
\text { wheat straw } \\
\text { powder }\end{array}$ & $\begin{array}{l}\text { Activated carbon obtained } \\
\text { from sawdust pellets was } \\
\text { used as catalyst carrier, and } \\
\text { p-toluene sulfonic acid was } \\
\text { the catalyst. Temperature: } \\
50-80^{\circ} \mathrm{C}\end{array}$ & $\begin{array}{l}\text { The heat value of both oils increased to } \\
25-29 \mathrm{MJ} / \mathrm{kg}\end{array}$ & 60 \\
\hline $\begin{array}{l}102 \mathrm{~mm} \text { i.d. } \\
\text { stainless steel } \\
\text { tube with a } \\
\text { reaction zone } \\
\text { length: } 457 \mathrm{~mm}\end{array}$ & $\begin{array}{lr}\begin{array}{l}\text { Slow } \\
\text { pine }\end{array} & \text { pyr. of } \\
\text { pellets } & \text { wood }\end{array}$ & $\begin{array}{l}\text { Vapors were contacted with } \\
\text { atomized ethanol }\end{array}$ & $\begin{array}{l}\text { The linear trend between weight hourly } \\
\text { space velocity (WHSV) and the yield. } \\
\text { Increasing WHSV, decreases total oily } \\
\text { phase yield and increases aqueous } \\
\text { phase yield. }\end{array}$ & 119 \\
\hline
\end{tabular}

\subsection{Water extraction}

When water is added to bio-oils (more than $35 \mathrm{wt}$. \% depending on bio-oil composition), a heavy tar-like phase (rich in lignin derived compounds) and an aqueous phase (rich in cellulose and hemicellulose derived compounds) are formed ${ }^{3}$. The water soluble phase is used for the production of liquid smoke for the food industry ${ }^{3}$. In fact, water extraction is often considered the first step for the recovery of chemicals from pyrolysis oils ${ }^{166}$. Vitasari recommends extracting the forest residues at a mass water-to-oil ratio of $0.65-0.7$ and the pine-derived oil at $0.5^{166}$. Upon water addition to the pyrolysis oil, $80-90 \%$ of the oxygenated can be extracted to the aqueous phase, based on their polarity ${ }^{166}$. Oasmaa et al. ${ }^{26}$ studied the conditions under which a separated phase was formed when water was added to bio-oil and found that bio-oil phase stability (the formation of an oily and aqueous phases) is controlled by the relative quantities of lignin oligomers (water insoluble materials), water and the sugars and the light $\mathrm{C} 1-\mathrm{C} 4$ molecules that act as solvents. Park et al. ${ }^{167}$ studied the separation of bio-oil fractions by adding the oil water, organic solvents (hexadecane and octane) and sodium hydroxide. As $\mathrm{pH}$ increases a bi-phase aqueous/organic occurred. 


\subsection{Extraction with organic solvents}

Organic solvent extractions is another strategy extensively studied in the literature ${ }^{168-173}$. Figure 4 shows two of the most common separation strategies used with bio-oil. The first one is based on the polarity of fractions and the second is an acid-base separation (see Figure 5).

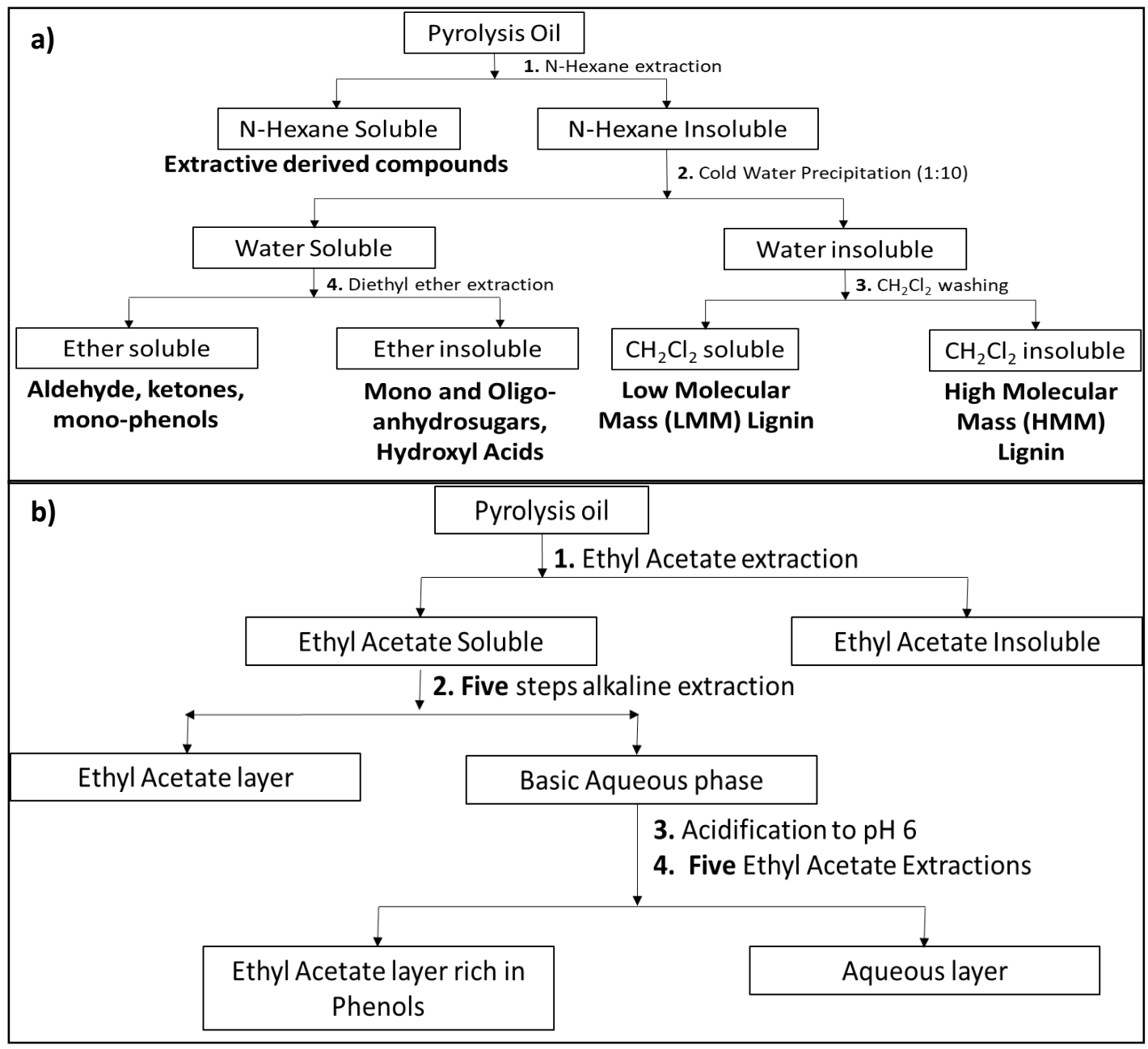

Figure 5. Common schemes used for bio-oil separation (a) based on polarity, (b) acid-base separation $^{171,174}$.

To choose a suitable liquid-liquid extraction is important to take into account the boiling point of the solvent used compared with the extractant ${ }^{117}$. We need to avoid the distillation of huge amounts of water or solvent which is very energy intensive ${ }^{117}$. The fraction of the solvent soluble in the pyrolysis oil rich phase is another parameter that need to be carefully considered when 
developing liquid-liquid extraction strategies ${ }^{175}$. Table 6 summarizes some of the most important liquid-liquid extraction studies reported in the literature.

Table 6. Solvent Extraction method

\begin{tabular}{|c|c|c|c|}
\hline System used & Variable studied & Observations & Ref. \\
\hline $\begin{array}{l}\text { Fractionation with water } \\
\text { and further extraction } \\
\text { with diethylether }\end{array}$ & $\begin{array}{l}\text { Physical properties and } \\
\text { chemical composition } \\
\text { correlations obtained }\end{array}$ & $\begin{array}{l}\text { The presence of volatile acids, water and alcohols } \\
\text { like methanol, affects properties like pH, } \\
\text { viscosity, pour point ash point and heating value }\end{array}$ & 173 \\
\hline $\begin{array}{l}\text { Extraction with ethyl } \\
\text { ether and } \\
\text { ethyl acetate }\end{array}$ & $\begin{array}{l}\text { Anti-fungal properties of } \\
\text { the oil fractions }\end{array}$ & $\begin{array}{l}\text { Anti-fungal properties were stronger in the } \\
\text { phenolic-rich fraction }\end{array}$ & 170 \\
\hline $\begin{array}{l}\text { Alkali and } \\
\begin{array}{l}\text { organic } \\
\text { solvents for phenols } \\
\text { separation }\end{array}\end{array}$ & $\begin{array}{l}\text { The effect of } \mathrm{pH} \text { on the } \\
\text { phenols recovery }\end{array}$ & $\begin{array}{l}\text { High } \mathrm{pH} \text { values }(12-13) \text { lead to a complete } \\
\text { extraction of phenols from the oil. }\end{array}$ & 174 \\
\hline $\begin{array}{l}\text { Steam distillation and } \\
\text { extraction of distillate oil } \\
\text { fraction obtained at } \\
105^{\circ} \mathrm{C} \text { using organic } \\
\text { solvents }\end{array}$ & $\begin{array}{l}\text { The best steam-to- } \\
\text { pyrolysis oil ratio for } \\
\text { recovery of syringol using } \\
\text { steam distillation }\end{array}$ & $\begin{array}{l}88.2 \% \text { recovery of total phenols was possible } \\
\text { with a steam-to-pyrolysis oil ratio of } 27 \text {. Syringol } \\
\text { with } 92.3 \% \text { purity was obtained through pentane } \\
\text { and water treatments. }\end{array}$ & 176 \\
\hline $\begin{array}{l}\text { Organic solvents for } \\
\text { sequential extraction of } \\
\text { bio-oil water extract }\end{array}$ & $\begin{array}{l}\text { Optimum solvent and } \\
\text { solvent-to-feed ratio }\end{array}$ & $\begin{array}{l}\text { Polar solvents (ethyl acetate and chloroform) are } \\
\text { better to recover chemicals from bio-oil aqueous } \\
\text { phase. The optimum solvent-to-feed ratio was } 2 \\
\text { for hexane, petroleum ether and for ethyl acetate, } \\
\text { and } 1 \text { for chloroform. }\end{array}$ & 177 \\
\hline $\begin{array}{l}\text { Liquid chromatographic } \\
\text { separation with silica gel } \\
\text { as stationary phase, and } \\
\text { hexane and ethyl acetate } \\
\text { as solvents. Extraction of } \\
\text { the aqueous phase using } \\
\text { diethyl ether. }\end{array}$ & $\begin{array}{l}\text { Miscibility of oil with } \\
\text { diesel and corrosivity. }\end{array}$ & $\begin{array}{l}\text { Excellent solubility in diesel and very mild } \\
\text { corrosivity to copper and stainless steel }\end{array}$ & 172 \\
\hline $\begin{array}{l}\text { Acetone followed by } \\
\text { extraction with } \\
\text { dichloromethane. } \\
\text { Extractives were } \\
\text { identified as n-hexane- } \\
\text { soluble material. }\end{array}$ & $\begin{array}{l}\text { The influence r of } \\
\text { extractives on phase } \\
\text { separation }\end{array}$ & $\begin{array}{l}10-20 \text { wt. \% top phase is formed depending on } \\
\text { the content of extractives of feedstock and } \\
\text { separation conditions. This phase can be removed } \\
y \text { hexane extraction. Besides, the amount of } \\
\text { extractives positively affects the proportion of } \\
\text { water insoluble fraction of top phase and the } \\
\text { solubility of forestry residue liquid. }\end{array}$ & 171 \\
\hline
\end{tabular}


Table 6. Continuation.......

\begin{tabular}{|c|c|c|c|}
\hline System used & Variable studied & Observations & Ref. \\
\hline $\begin{array}{l}\text { Water wash followed by } \\
\text { extraction with organic } \\
\text { compounds }\end{array}$ & $\begin{array}{l}\text { Yield and composition of the } \\
\text { different bio-oil fractions obtained }\end{array}$ & $\begin{array}{l}\text { Top phase water-insoluble material (60- } \\
90 \text { wt. \%) includes lignin-based } \\
\text { constituents and extractives (35-50 wt. } \\
\%) \text {. The bottom phase chemical } \\
\text { composition of forestry residue liquid is } \\
\text { similar to that of pine pyrolysis liquid: } 8 \text { - } \\
10 \text { wt. \% of volatile acids, } 10-15 \text { wt. \% } \\
\text { aldehydes and ketones, } 25-30 \text { wt. \% } \\
\text { water, } 30-35 \text { wt. \% of "sugar } \\
\text { constituents". }\end{array}$ & 178 \\
\hline $\begin{array}{l}\text { Pyrolysis liquids } \\
\text { extracted with water. } \\
\text { The water-insoluble } \\
\text { fraction further extracted } \\
\text { with dichloromethane, } \\
\text { and the water-soluble } \\
\text { fraction with diethyl } \\
\text { ether } \\
\text { dichloromethane. and }\end{array}$ & $\begin{array}{l}\text { Changes in physical properties and } \\
\text { chemical composition of pyrolysis } \\
\text { oils during storage }\end{array}$ & $\begin{array}{l}\text { There was an increase in the water- } \\
\text { insolubles fraction with storage, with } \\
\text { lead to an increase in the average } \\
\text { molecular mass and the viscosity of the } \\
\text { liquid. In the first } 3 \text { months the ether- } \\
\text { insolubles decreased and the high- } \\
\text { molecular-mass lignin material increased } \\
\text { very fast, leveling off afterwards. }\end{array}$ & 179 \\
\hline \multicolumn{4}{|c|}{ Reactive Extraction } \\
\hline $\begin{array}{l}\text { Long chain ternary } \\
\text { amines (trioctylamine) } \\
\text { for acetic acid removal }\end{array}$ & $\begin{array}{l}\text { Type and concentration of amine } \\
\text { and co-solvents (THF, octane), } \mathrm{T}= \\
20^{\circ} \mathrm{C} \text {. }\end{array}$ & $\begin{array}{l}\text { More than } 90 \% \text { of acetic acid can be } \\
\text { extracted in a single step. }\end{array}$ & 175 \\
\hline
\end{tabular}

\subsection{Temperature-swing extraction:}

Kumar et al. ${ }^{180}$ studied bio-oil fractionation by temperature-swing extraction. The method consists on the hot solvent extraction at $70{ }^{\circ} \mathrm{C}$ of the light fraction of the oil with an appropriate solvent followed by cold de-mixing at $25{ }^{\circ} \mathrm{C}$ of the light fraction and the extraction solvent. The authors use the Hansen solubility distance $(\mathrm{Ra})$ which take into account the dispersion forces, dipole forces and hydrogen bonding to explain their results. The light solvent is recovered by the spontaneous liquid/liquid separation upon cooling the extract. The authors ${ }^{180}$ screened several solvents: alcohols (methanol, ethanol, 1-butanol, 1-octanol, glycerol), alkanes (n- $\mathrm{C}_{6}, \mathrm{n}-\mathrm{C}_{7}, \mathrm{n}-\mathrm{C}_{8}$, $\mathrm{n}-\mathrm{C}_{11}, \mathrm{n}-\mathrm{C}_{12}, \mathrm{n}-\mathrm{C}_{16}$, cyclo-hexane) and others (acetic acid, furfural, diethylether, toluene, ethylbenzene, water, mixtures of water and methanol). For the regeneration of the extraction solvent immiscibility at room temperature is needed.

\subsection{Supercritical fluid extraction}

Supercritical fluid extraction (SFE) is typically conducted with $\mathrm{CO}_{2}$. This technique is suitable for extraction of hydrophobic constituents ${ }^{117}$. The advantage of SFE are speed (no surface 
tension, low viscosities, fast diffusivity) and selectivity but requires high pressure which increases costs compared with other liquid-liquid extraction methods. Selectivity can be altered by changing pressure and temperature. In many cases SFE is used to avoid water distillation ${ }^{117}$. Notably, the evaporation of water costs in terms of thermal energy $2.26 \mathrm{MJ} \mathrm{kg}^{-1}$, while the $\mathrm{CO}_{2}$ recompression to supercritical conditions requires up to $0.54 \mathrm{MJ} \mathrm{kg}^{-1}$ or $1.3 \mathrm{MJ} \mathrm{kg}^{-1}$ equivalent thermal energy when considering electricity generation.

Table 7. Example of bio-oil supercritical fluid extraction methods

\begin{tabular}{|c|c|c|c|c|}
\hline System used & Bio-oil source & Operation conditions & Observations & Ref \\
\hline $\begin{array}{l}\mathrm{SC}-\mathrm{CO}_{2} \\
\text { extraction (EV- } \\
3-50-2)\end{array}$ & $\begin{array}{l}\text { Pyrolysis of } \\
\text { palm kernel } \\
\text { shell }\end{array}$ & $48^{\circ} \mathrm{C}, 28 \mathrm{MPa}$ & $\begin{array}{l}\text { Quadratic model developed. Extract } \\
\text { enriched with acids and esters. }\end{array}$ & 181 \\
\hline $\begin{array}{l}\mathrm{SC}-\mathrm{CO}_{2} \text { unit } \\
\text { (Thar } \\
\text { Technologies) }\end{array}$ & $\begin{array}{l}\text { Pyrolysis of } \\
\text { wheat - wood } \\
\text { sawdust biomass }\end{array}$ & $45^{\circ} \mathrm{C}, 25 \mathrm{MPa}$ & $\begin{array}{l}\text { Effective water separation. Amount } \\
\text { of furanoids, pyranoids and } \\
\text { bezenoids improved in the first SC- } \\
\mathrm{CO}_{2} \text { fraction. Later fractions } \\
\text { enriched in fatty acids (44\%) and } \\
\text { high MW alcohols }(5.3 \%)\end{array}$ & 182 \\
\hline $\begin{array}{l}\mathrm{SC}-\mathrm{CO}_{2} \text { unit } \\
\text { (HDT Sigmar } \\
\text { Mothes) }\end{array}$ & $\begin{array}{l}\text { Pyrolysis of pine } \\
\text { wood biomass }\end{array}$ & $\begin{array}{l}60-80^{\circ} \mathrm{C}, 10-30 \mathrm{MPa} ; \mathrm{SiO}_{2} \\
\text { and activated carbon as } \\
\text { carriers. Optimum condition: } \\
60^{\circ} \mathrm{C}, 30 \mathrm{MPa} \text {, with } \mathrm{SiO}_{2} \text { as } \\
\text { carrier }\end{array}$ & $\begin{array}{l}\text { Soluble Oil yield at } 20 \mathrm{MPa}-6-13 \\
\text { wt.\%. At } 30 \mathrm{MPa}: 13-14 \mathrm{wt} . \% \text {. } \\
\text { With exception of levoglucosan, low } \\
\text { MW componts in the extracts. }\end{array}$ & 183 \\
\hline $\begin{array}{l}\mathrm{SC}-\mathrm{CO}_{2} \text { unit } \\
\text { (Thar } \\
\text { Technologies) }\end{array}$ & $\begin{array}{l}\text { Fast pyrolysis of } \\
\text { wheat-hemlock }\end{array}$ & $40^{\circ} \mathrm{C}, 10,25$ and $30 \mathrm{MPa}$ & $\begin{array}{l}10-25 \mathrm{MPa} \text { : extracted fractions } \\
\text { enriched with furanoids, pyranoids } \\
\text { and bezenoids. } 30 \mathrm{MPa} \text { : extracted } \\
\text { fractions enriched with fatty acids } \\
\text { and alcohols. }\end{array}$ & 184 \\
\hline $\begin{array}{l}\mathrm{SC}-\mathrm{CO}_{2} \\
\text { (reservoir, } \\
\text { pump, an } \\
\text { stirred } \\
\text { autoclave } \\
\text { extractor, water } \\
\text { bath and } \\
\text { separator) }\end{array}$ & $\begin{array}{l}\text { Flash pyrolysis } \\
\text { of pulverized } \\
\text { corn stalk. }\end{array}$ & $\begin{array}{l}45^{\circ} \mathrm{C}, 7-17 \mathrm{MPa}, 45^{\circ} \mathrm{C}, 7-30 \\
\mathrm{MPa} \text {. Effect of temperature } \\
\text { on extraction: Simulated } \\
\text { bio-oil: } 15 \mathrm{MPa}, 35-60^{\circ} \mathrm{C} \text {, } \\
\text { Real bio-oil: } 30 \mathrm{MPa}, 45- \\
65^{\circ} \mathrm{C}\end{array}$ & $\begin{array}{l}\text { Total ketones, phenols and } \\
\text { aldehydes increased, while the acids } \\
\text { and water percentage significantly } \\
\text { decreased. Maximum extraction } \\
\text { efficiency of real bio-oil reached } \\
88.6 \% \text { at } 30.0 \mathrm{MPa} \text { and } 35^{\circ} \mathrm{C} \text {. }\end{array}$ & 185 \\
\hline $\begin{array}{l}\text { Commercial } \\
600 \mathrm{ml} \mathrm{SC}-\mathrm{CO}_{2} \\
\text { extraction } \\
\text { (HDT Sigmar } \\
\text { Mothes, Berlin, } \\
\text { Germany) }\end{array}$ & $\begin{array}{l}\text { Slow pyrolysis } \\
\text { of beech wood } \\
\text { and fast } \\
\text { pyrolysis of } \\
\text { beech wood }\end{array}$ & $60 \circ \mathrm{C}, 15-25 \mathrm{MPa}$ & $\begin{array}{l}\text { Yield of extracts from slow pyrolysis } \\
\text { oil and fast pyrolysis oil over } 50 \text { and } \\
10 \% \text {, respectively. Extraction } \\
\text { significantly reduced water content, } \\
\text { and increased carbon content. } \\
\text { Extracts lighter than original } \\
\text { pyrolysis oil. Residues have higher } \\
\text { molecular weight compared with } \\
\text { original pyrolysis oils. }\end{array}$ & 186 \\
\hline
\end{tabular}


Table 7. Continuation.......

\begin{tabular}{|c|c|c|c|c|}
\hline System used & Bio-oil source & & Observations & Ref. \\
\hline $\begin{array}{l}\mathrm{SC}-\mathrm{CO}_{2} \text { unit } \\
\left(640 \mathrm{~cm}^{3}, \mathrm{HDT}\right. \\
\text { Sigmar Mothes, } \\
\text { Berlin, } \\
\text { Germany) }\end{array}$ & $\begin{array}{l}\text { Slow pyrolysis } \\
\text { of beech wood }\end{array}$ & $\begin{array}{l}60{ }^{\circ} \mathrm{C}, 20 \mathrm{MPa}, \mathrm{SiO}_{2} \text { as } \\
\text { carrier (two weight ratios: } \\
100: 80 \text { and } 100: 40 \text { ), total } \\
\text { extraction time: } 6 \mathrm{~h}, \mathrm{SC}-\mathrm{CO}_{2} \\
\text { flowrate: } 500 \mathrm{~g} \mathrm{~h}^{-1}\end{array}$ & $\begin{array}{l}\mathrm{SC}-\mathrm{CO}_{2} \text { extraction gives higher yield } \\
\text { than with hexane and acetone. Non- } \\
\text { aromatic compounds increased in SC- } \\
\mathrm{CO}_{2} .\end{array}$ & 187 \\
\hline $\begin{array}{l}{\mathrm{SC}-\mathrm{CO}_{2}}_{\text {unit }} \\
\text { (MV-10 ASFE, } \\
\text { Waters, USA) }\end{array}$ & $\begin{array}{l}\text { Fast pyrolysis of } \\
\text { red pine }\end{array}$ & $\begin{array}{l}50^{\circ} \mathrm{C} \text {, Solvent flow rate: } 1.0 \\
\mathrm{~mL} \mathrm{~min}{ }^{-1} . \text { Step } 1: 5 \mathrm{~min}, 10 \\
\mathrm{MPa} \text {, pure } \mathrm{SC}-\mathrm{CO}_{2} ; \text { Step } 2: \\
25 \mathrm{~min}, 20 \mathrm{MPa}, 90 \% \mathrm{SC}- \\
\mathrm{CO}_{2} \text { and } 10 \% \text { methanol; } \\
\mathrm{Step} 3: 40 \mathrm{~min}, 30 \mathrm{MPa} \text {, } \\
75 \% \mathrm{SC}-\mathrm{CO}_{2} \text { and } 25 \% \\
\text { methanol. }\end{array}$ & $\begin{array}{l}\text { Yields of extracted fractions } 1,2 \text { and } \\
3: 13.4 \text { wt. } \%, 24.8 \text { wt. \%, and } 32.9 \\
\text { wt. \% (A total of } 71.1 \text { wt. \% of the } \\
\text { raw bio-oil). Phenols content } \\
\text { increased in fraction 1. Fractions } 2 \\
\text { and } 3 \text { enriched in carbohydrates. } \\
\text { Fraction } 1 \text { enriched in lipids, Fraction } \\
3 \text { enriched in lignin and condensed } \\
\text { aromatics. }\end{array}$ & 188 \\
\hline
\end{tabular}

\subsection{Solid-liquid extraction:}

Solid-liquid extraction is based on the affinity of solutes for a solid phase through which the sample is passed. Table 8 summarizes the studies conducted this technique for the separation of pyrolysis oil fractions.

Table 8. Example of bio-oil solid-liquid extraction methods

\begin{tabular}{|c|c|c|c|c|}
\hline System used & Bio-oil source & $\begin{array}{l}\text { Operation } \\
\text { conditions }\end{array}$ & Observations & Ref. \\
\hline $\begin{array}{llr}\text { Sepabeads } & \text { resin } & \text { SP207 } \\
\text { (Mitsubishi } & \text { Chemical) and } \\
\text { Amberlite XAD4 resin } \\
\text { (Rohm and Hass) }\end{array}$ & $\begin{array}{l}\text { Fast pyrolysis of } \\
\text { red oak }\end{array}$ & $\begin{array}{l}\text { Room temperature. } \\
1: 1 \text { water extraction } \\
\text { of the first stage. } \\
\text { Kinetic adsorption: } \\
22^{\circ} \mathrm{C}, 500 \mathrm{rpm}, 2 \\
\text { hours of sampling; }\end{array}$ & $\begin{array}{l}\text { Adsorption capacity and affinity } \\
\text { for phenolic species is higher } \\
\text { than for levoglucosan. } \\
\text { There might be mass transfer } \\
\text { limitation of phenolics in column } \\
\text { chromatographic separation. }\end{array}$ & 189 \\
\hline $\begin{array}{l}\text { A strong-base anion } \\
\text { exchange resin (Amberlyst } \\
\text { A26) and a weak-base anion } \\
\text { exchange (Amberlite IRA- } \\
67) \text {. }\end{array}$ & $\begin{array}{l}\text { Model solutions } \\
\text { prepared by } \\
\text { dissolving } \\
\text { phenol in double } \\
\text { distilled water. }\end{array}$ & $\begin{array}{l}\text { Flow rate: } 10 \mathrm{~L} \mathrm{~h}^{-1} \\
\text { and } \\
\text { temperature. } \\
\text { Recirculation } \\
60 \mathrm{~min} \text {. }\end{array}$ & $\begin{array}{l}\text { Phenols removal efficiency } \\
\text { increased with recirculation time } \\
\text { for both resins, and decreased } \\
\text { with initial phenol solution } \\
\text { concentration. }\end{array}$ & 190 \\
\hline
\end{tabular}




\subsection{Membrane separation:}

Membrane separation, such as microfiltration $(0.05-10 \mu \mathrm{m})$, ultrafiltration $(1-100 \mathrm{~nm})$ and nanofiltration $(<2 \mathrm{~nm})$ has been bio-oil fractionation ${ }^{116}$ (see Table 9).

Table 9. Example of membrane separation studies relevant for bio-oil refining.

\begin{tabular}{|c|c|c|c|c|}
\hline System used & Feed & $\begin{array}{l}\text { Operation } \\
\text { conditions }\end{array}$ & Observations & Ref. \\
\hline $\begin{array}{l}\text { Laboratory- scale separation unit, } \\
\text { with solvent-resistant membranes } \\
\text { prepared from polyimides based on } \\
\text { PMDA and BPDA by the dry/wet } \\
\text { phase-inversion technique }\end{array}$ & $\begin{array}{l}\text { Model } \\
\text { mixtures of } \\
\text { 1-propanol, } \\
\text { acetic acid at } \\
\text { concentrations: } \\
\text { of 10-90 wt. \% }\end{array}$ & $\begin{array}{l}85-135^{\circ} \mathrm{C}, \quad 20- \\
66 \mathrm{kPa} \text { (feed) } \\
\text { and } 4-5 \mathrm{kPa} \\
\text { (permeate). } \\
\text { The composition } \\
\text { of each fraction } \\
\text { was determined. }\end{array}$ & $\begin{array}{l}\text { Polyimides with diamine and } \\
\text { dianhydride moieties } \\
\text { membranes: } \\
\text { permeability and selectivity. } \\
\text { Copolyimide } \\
\text { 50DDS/50ODA and PMDA- } \\
\text { 50DDS/50ODA membranes: } \\
\text { better mechanical and } \\
\text { chemical properties. }\end{array}$ & 191 \\
\hline $\begin{array}{l}\text { Five dense polyimide membranes } \\
\text { (PMDA-50DDS/50ODA, BPDA- } \\
\text { 50DDS/50ODA, BPDA-DDS, } \\
\text { BPDA-ODA, and DSDA-TPER) }\end{array}$ & Water vapor & $\begin{array}{l}\text { Gravimetric } \\
\text { method. } \\
85^{\circ} \mathrm{C}, 40 \mathrm{kPa} \\
(\text { feed) and 1.5- } \\
2 \mathrm{kPa} \text { (permeate). } \\
\text { After } 6-8 \mathrm{~h} \text {, the } \\
\text { condensed } \\
\text { vapors of the } \\
\text { permeate } \\
\text { samples were } \\
\text { collected. }\end{array}$ & $\begin{array}{l}\text { Both the dual-mode sorption } \\
\text { model and the GAB model } \\
\text { successfully represented the } \\
\text { sorption isotherms of water } \\
\text { vapor in the polyimides. } \\
\text { Water vapor transfer highest } \\
\text { for DSDA-TPER and } \\
\text { PMDA-50DDS/50ODA }(1.6 \\
\left.\times 10^{-13}\right) \text {, and the lowest for } \\
\text { BPDA-ODA }\left(2.0 \times 10^{-14}\right) \text {. }\end{array}$ & 192 \\
\hline $\begin{array}{l}\text { Polyetherimide/polyvinylpyrrolidone } \\
\text { membranes. Prepared by the wet- } \\
\text { phase inversion method }\end{array}$ & $\begin{array}{l}\text { Water and } \mathrm{n}- \\
\text { propanol } \\
\text { mixture } \\
\mathrm{m} / \mathrm{m})\end{array}$ & $\begin{array}{l}85^{\circ} \mathrm{C}, \quad 33 \mathrm{kPa} \\
\text { (feed) and } 7 \mathrm{kPa} \\
\text { (permeate) }\end{array}$ & $\begin{array}{l}\text { Increasing the total polymer } \\
\text { concentration in the casting } \\
\text { solution decreased the } \\
\text { permeation rates for both } \\
\text { water and n-propanol, and } \\
\text { increased the membrane } \\
\text { selectivity. }\end{array}$ & 193 \\
\hline
\end{tabular}


Table 9. Continuation.........

\begin{tabular}{|c|c|c|c|c|}
\hline System used & Feed & $\begin{array}{l}\text { Operation } \\
\text { conditions }\end{array}$ & Observations & Ref. \\
\hline $\begin{array}{l}\text { Polycrystalline silicalite and ZSM-5 } \\
\text { membranes on sintered stainless } \\
\text { steel support and on porous alumina } \\
\text { support }\end{array}$ & $\begin{array}{l}\text { Aqueous } \\
\text { solution of } \\
\text { acetic acid or } \\
\text { ethanol (2.5-10 } \\
\text { vol.\%) }\end{array}$ & $\begin{array}{l}\text { Pervaporation } \\
\text { experiment: } \\
\text { standard } \\
\text { pervaporation } \\
\text { cell, down } \\
\text { stream pressure } \\
<2 \text { Torr. }\end{array}$ & $\begin{array}{l}\text { Silicalite membrane on the } \\
\text { sintered stainless steel support } \\
\text { permeates acetic acid in } \\
\text { preference to water in the } \\
\text { region of } 5 \text { to } 40 \text { vol\% of } \\
\text { acetic acid in the feed. Porous } \\
\text { alumina membrane did not } \\
\text { separate acetic acid from the } \\
\text { aqueous solution. }\end{array}$ & 194 \\
\hline $\begin{array}{l}\text { Poly(vinyl alcohol) (PVA) } \\
\text { membranes crosslinked with } \\
\text { glutaraldehyde (GA) }\end{array}$ & $\begin{array}{l}70 \text { - } 90 \text { wt. } \\
\% \text { acetic acid } \\
\text { in water. }\end{array}$ & $\begin{array}{l}\text { Pervaporation } \\
\text { experiment: } 35- \\
50^{\circ} \mathrm{C} \text {; permeate } \\
\text { pressure } \quad< \\
5 \mathrm{mmHg} \text {. Liquid } \\
\text { nitrogen was } \\
\text { used as cooling } \\
\text { agent for cold } \\
\text { trap. }\end{array}$ & $\begin{array}{l}\text { Swelling behavior controlled } \\
\text { by crosslinking density or by } \\
\text { the formation of chemical } \\
\text { groups such as acetal and } \\
\text { aldehyde groups. } \\
\text { Separation factor: } 120-420 \\
\text { and flux of } 29-263 \mathrm{~g} / \mathrm{m}^{2} \mathrm{~h} \\
\text { (membrane prepared at } 5 \mathrm{vol} \\
\% \text { of GA solution) }\end{array}$ & 195 \\
\hline $\begin{array}{lrr}\begin{array}{l}\text { Acrylonitrile } \\
\text { poly(vinyl }\end{array} & \text { (AN) } & \text { grafted } \\
\text { membranes } & & \text { (PVA) }\end{array}$ & $\begin{array}{l}10-90 \text { wt.\% } \\
\text { acetic acid }\end{array}$ & $\begin{array}{l}25-50^{\circ} \mathrm{C} ; \\
\text { Effective } \\
\text { membrane area } \\
\text { of } 12.5 \mathrm{~cm}^{2} ; \\
\text { Pressure at } \\
\text { downstream } \\
\text { side:23 KPa }\end{array}$ & $\begin{array}{l}\text { Increase of downstream } \\
\text { pressure improved permeation } \\
\text { rate but separation factor } \\
\text { decreased. } \\
\text { PVA-g-AN membranes have } \\
\text { lower permeation and grater } \\
\text { separation factors compared to } \\
\text { PVA membranes. }\end{array}$ & 196 \\
\hline $\begin{array}{l}\text { Two copolyimide dense and } \\
\text { asymmetric capillary membranes of } \\
\text { PMDA-50DDS/50ODA and BPDA- } \\
\text { 50DDS/ 50ODA }\end{array}$ & $\begin{array}{l}\text { Pure water, 1- } \\
\text { propanol/water } \\
\text { and acetic } \\
\text { acid/water } \\
\text { blends }\end{array}$ & 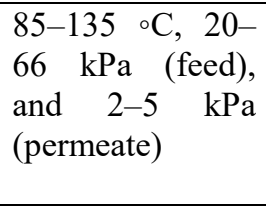 & $\begin{array}{l}\text { Skin layer effective thickness } \\
\text { was used to simulate the water } \\
\text { vapor sorption and transport } \\
\text { behavior }\end{array}$ & 197 \\
\hline $\begin{array}{l}\text { Polyimide dense membranes } \\
\text { (PMDA-50DDS/50ODA, BPDA- } \\
\text { 50DDS/50ODA, BPDA-DDS, } \\
\text { BPDA-ODA, and DSDA-TPER) }\end{array}$ & $\begin{array}{l}\text { 1-propanol, } \\
\mathrm{H} 2 \mathrm{O} \text { acetic } \\
\text { acid and } \\
\text { aqueous phase } \\
\text { containing } 11 \\
\text { wt.\% organic } \\
\text { compounds as } \\
\text { vapor feeds }\end{array}$ & $\begin{array}{l}85-135{ }^{\circ} \mathrm{C} ; 20- \\
63 \mathrm{kPa} \text { (feed), } \\
\text { and } 1.5-2 \mathrm{kPa} \\
\text { (permeate); } \\
\text { Retentate vapor } \\
\text { was condensed. }\end{array}$ & $\begin{array}{l}\text { Better separation of water } \\
\text { vapor from organics at low } \\
\text { temperature in polyimide } \\
\text { membranes. }\end{array}$ & 198 \\
\hline
\end{tabular}


Table 9. Continuation.........

\begin{tabular}{|c|c|c|c|c|}
\hline System used & Feed & $\begin{array}{l}\text { Operation } \\
\text { conditions }\end{array}$ & Observations & Ref. \\
\hline $\begin{array}{l}\text { Chemically crosslinked poly (vinyl } \\
\text { alcohol) (PVA) membranes }\end{array}$ & $\begin{array}{lr}0 \quad \text { to } & 100 \% \\
\text { acetic } & \text { acid } \\
\text { solution } & \end{array}$ & $\begin{array}{l}30,45,60 \text { and } \\
75^{\circ} \mathrm{C}, \text { pressure }< \\
5 \mathrm{mmHg} \text { at the } \\
\text { downstream side. }\end{array}$ & $\begin{array}{l}\text { Separation factor of } 13-42 \text { and } \\
\text { permeation rate of } 79-2285 \\
\mathrm{~g} / \mathrm{m}^{2} \mathrm{~h} \text { achieved. The strongest } \\
\text { permeation was between } 50 \\
\text { and } 70 \text { wt. } \% \text { composition. }\end{array}$ & 199 \\
\hline $\begin{array}{l}\text { Ge-substituted ZSM-5 membrane } \\
\text { on a porous, tubular, stainless steel } \\
\text { support }\end{array}$ & $\begin{array}{l}5 \text { wt. } \% \text { acetic } \\
\text { acid }\end{array}$ & $\begin{array}{l}363-303 \mathrm{~K},<0.5 \\
\mathrm{kPa} \text { (permeate } \\
\text { side). } \\
\text { Liquid nitrogen } \\
\text { was used as } \\
\text { cooling agent for } \\
\text { cold trap. }\end{array}$ & $\begin{array}{l}\text { Separation of acetic acid from } \\
\text { water was more efficient using } \\
\text { Ge-ZSM- } 5 \text { membrane than } \\
\text { silicalite- } 1 \text { membrane. A total } \\
\text { flux of } 0.43 \mathrm{~kg} /\left(\mathrm{m}^{2} \mathrm{~h}\right) \text { and an } \\
\text { acid/water selectivity of } 14 \\
\text { were achieved by Ge-ZSM-5 } \\
\text { membrane at } 363 \mathrm{~K} \text { and } 5 \% \\
\text { acetic acid. }\end{array}$ & 200 \\
\hline $\begin{array}{l}\text { Two different LiquiCel Membrane } \\
\text { Contactors (Membrana, Charlotte, } \\
\text { NC): MiniModule } 1 \times 5.5 \text { and Extra- } \\
\text { Flow } 2.5 \times 8 \text { both with } \\
\text { polypropylene membranes }\end{array}$ & $\begin{array}{l}\text { Aqueous } \\
\text { phase: } \\
\text { Pretreated corn } \\
\text { stover } \\
\text { hydrolysate; } \\
\text { Organic phase: } \\
\text { octanol and } \\
\text { Alamine } 336 \\
\text { or octanol and } \\
\text { Aliquat } 336\end{array}$ & - & $\begin{array}{l}\text { Over } 60 \% \text { of acetic acid } \\
\text { removed using Alamine } 336 \text {. } \\
\text { Extraction rates were lower for } \\
\text { Aliquat } 336 . \text { There is a } \\
\text { coextraction of bisulphate } \\
\text { anion, which is preferentially } \\
\text { extracted at pH values below } \\
\text { its pKa. }\end{array}$ & 201 \\
\hline
\end{tabular}

\section{Strategies for Purification and Separation of Targeted Compounds}

Based on bio-oil composition there are only four compounds that are in concentrations sufficiently high as to explore their separation (acetic acid, hydroxyacetaldehyde, acetol and levoglucosan). Furthermore, there are group of compounds that could be commercialized as fractions (mono and oligo-phenols, sugars and dehydrated sugars). In this section we review how some of these compounds are separated from other aqueous solutions with methods that can be of great value for bio-oil refining.

\subsection{Methods for Acetic Acid (HAc) Separation}

As discussed above, a fraction rich in acetic acid can be produced using fractional condensation systems ${ }^{120,122-125,134,135,202-206}$. Figure 7 summarizes the methods reported in the literature for acetic acid separation from aqueous solutions. 


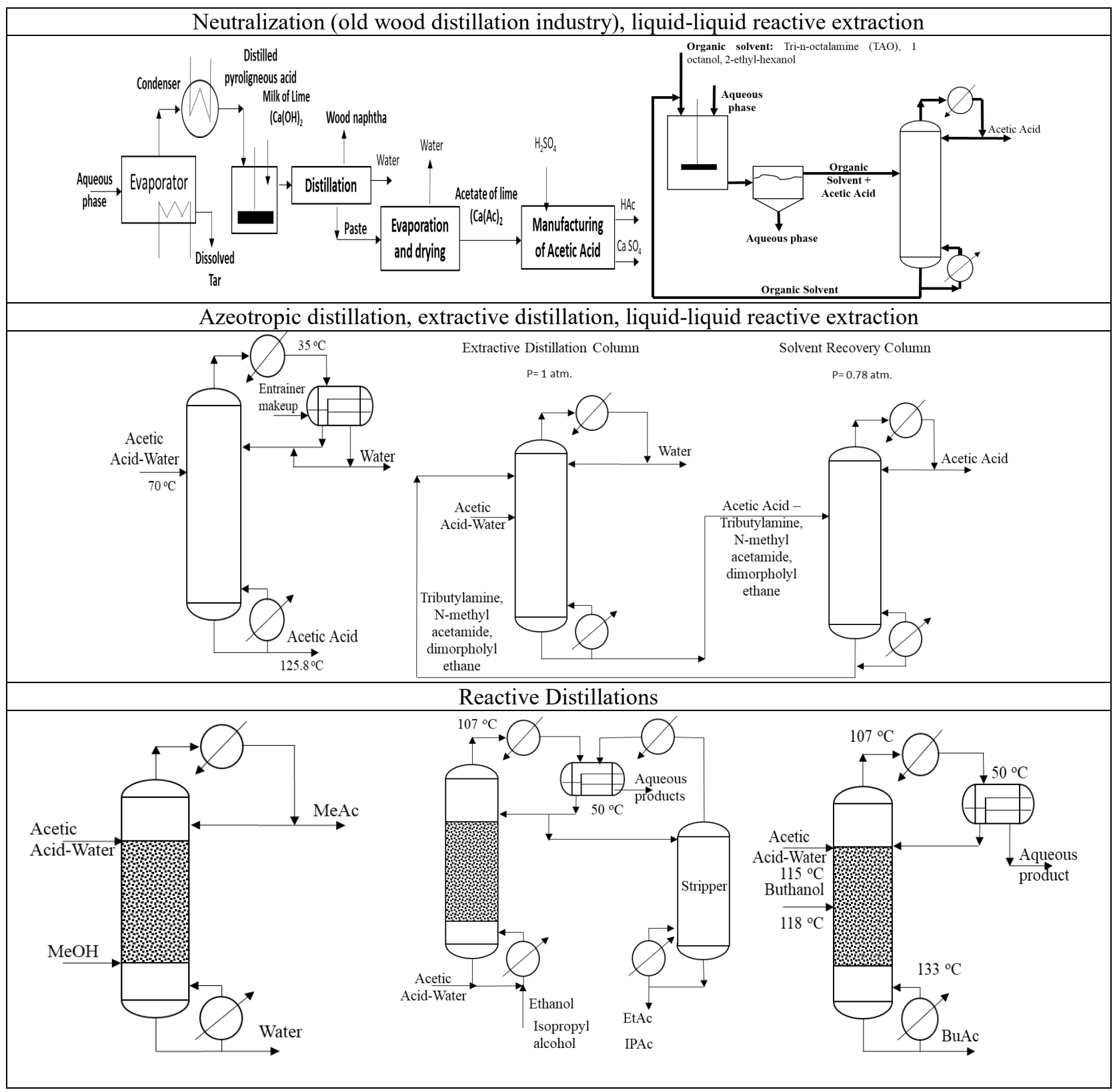

Figure 6. Summary of methods reported in the literature for Acetic Acid separation from aqueous phases 
In the old wood distillation industry the acetic acid was separated by precipitation with lime ${ }^{207}$. In this process the aqueous phase (also known as pyrolygneous water) is evaporated to separate the dissolved tar from the light compounds. The distilled pyroligneous acid is then neutralized with milk of lime $\left(\mathrm{Ca}(\mathrm{OH})_{2}\right)$ and the resulting solution distilled to separate the wood naphata and a paste rich in acetate of lime $\left(\mathrm{CaAc}_{2}\right)$. This paste is concentrated by evaporation and drying and is and commercialized ${ }^{207}$.

Ijmker, et al. ${ }^{208}$ studied extraction of acetic acid using fatty acids (hexanoic and heptanoic acids). The approach showed promising results. The selectivity of fatty acids over water was 12 for hexanoic acid and 24 for heptanoic acid allowing significant concentration through extraction. This high extraction was explained by the dimerization of carboxylic acid in liner or cyclic forms. The authors ${ }^{208}$ developed a mathematical model to describe the extraction with hexanoic acid that take into account the dissociation equilibrium of compounds in the system. Other methods under study to recovery acetic acid can be found elsewhere ${ }^{18,177,209,210}$ and are summarized in table 10 . 
Table 10. Summary of acetic acid separation methods

\begin{tabular}{|c|c|c|c|}
\hline System used & Operation conditions & Observations & Ref. \\
\hline \multicolumn{4}{|c|}{ Azeotropic distillation } \\
\hline $\begin{array}{l}\text { Simulation with } \\
\text { ChemCad, } \\
\text { Aspen Plus. } \\
\text { Column diameter } \\
=0.3259 \mathrm{~m} \text {; tray } \\
\text { spacing }=0.6096 \\
\text { m. } 10 \quad \text { min } \\
\text { holdup. }\end{array}$ & $\begin{array}{l}\text { Entrainers used: } \mathrm{p} \text {-xylene, isobutyl acetate, ethyl } \\
\text { acetate, n-butyl acetate. Pressure: } 1.1 \text { atm., } \\
\text { Reboiler temperature: } 125.8{ }^{\circ} \mathrm{C} \text {, Condenser } \\
\text { Temperature: } 35{ }^{\circ} \mathrm{C} \text {. Vapor-liquid-liquid } \\
\text { equilibrium calculated from the Nonrandom } \\
\text { two-liquid (NRTL) activity coefficient model } \\
\text { and second virial coefficient of the Hayden- } \\
\text { O'Connell model }\end{array}$ & $\begin{array}{l}\text { Iso-butyl acetate was the best } \\
\text { entrainer with total annual cost only } \\
\text { about } 55 \% \text { of the system without any } \\
\text { entrainer. }\end{array}$ & $\begin{array}{l}211, \\
212\end{array}$ \\
\hline \multicolumn{4}{|c|}{ Extractive distillation } \\
\hline $\begin{array}{l}\text { Two extractive } \\
\text { distillation } \\
\text { columns and } \\
\text { solvent recovery } \\
\text { column. } \\
\text { Extractive } \\
\text { distillation } \\
\text { column } \\
\text { simulated. } \\
\text { Mathematical } \\
\text { model of } \\
\text { equilibrium stage }\end{array}$ & $\begin{array}{l}\text { Tributylamine was the separating agent. Take } \\
\text { advantage of the reversible reaction between } \\
\text { acetic acid and tributylamine: } \\
\qquad \mathrm{HAC}+\mathrm{R}_{3} \mathrm{~N}-\mathrm{R}_{3} \mathrm{NH}^{+}+\mathrm{OOCCH}_{3}^{-} \\
\text {Number of theoretical plates: } 25 \text {. The solvent } \\
\text { recovery column had } 20 \text { plates. The extractive } \\
\text { distillation column was run at normal pressure, } \\
\text { and the solvent recovery column was run at } \\
0.080 \mathrm{MPa} \text {. The solvent was recycled from the } \\
\text { recovery column to the extractive distillation } \\
\text { column. }\end{array}$ & $\begin{array}{l}\text { High-purity of water was obtained at } \\
\text { the top of extractive distillation } \\
\text { column for small solvent/feed volume } \\
\text { ratio and reflux ratio. Therefore, } \\
\text { tributylamine seems to be a good } \\
\text { separating agent for water and acetic } \\
\text { acid mixture. Mathematical model } \\
\text { was developed. }\end{array}$ & 213 \\
\hline $\begin{array}{l}\text { Continuous } \\
\text { experimental } \\
\text { system. }\end{array}$ & $\begin{array}{l}\text { Proposed a process for preparing technically } \\
\text { pure acetic acid from water-acetic acid mixtures } \\
\text { with N-methyl acetamide as an improvement of } \\
\text { a process with dimorpholyl ethane }\end{array}$ & $\begin{array}{l}\text { Acetic acid purity vary between } 99.8 \\
\text { and } 99.9 \% \text {. N-methyl acetamide was } \\
\text { chemically and thermally stable }\end{array}$ & 214 \\
\hline \multicolumn{4}{|c|}{ Reactive Distillations } \\
\hline $\begin{array}{l}\text { Packed reactive } \\
\text { distillation } \\
\text { column with } \\
\text { three sections: } \\
\text { non-reactive } \\
\text { stripping section; } \\
\text { catalytic packed } \\
\text { section and non- } \\
\text { reactive } \\
\text { enriching section }\end{array}$ & $\begin{array}{l}\text { Catalytic section: packed with macroporous } \\
\text { Indion } 130 \text { ion-exchange resin (catalyst bed), } \\
\text { confined in stainless steel wire mesh tea bags. } \\
\text { The feeds were injected at room temperature. } \\
\text { Several column configurations (A-G) were } \\
\text { adopted for recovery of acetic acid. } \\
\text { Maximum recovery when acetic acid is inserted } \\
\text { from the top and n-butanol/iso-amyl alcohol is } \\
\text { introduced from the bottom. }\end{array}$ & $\begin{array}{l}\text { At } 1: 2 \text { mole ratio of acetic acid to } n- \\
\text { butanol: } 58 \% \text { conversion of acetic } \\
\text { acid achieved. And } 1: 2 \text { mole ratio of } \\
\text { acetic acid to iso-amyl alcohol, } \\
\text { around } 51 \% \text { conversion of acetic } \\
\text { acid was achieved. Best result when } \\
\text { the column operated in counter- } \\
\text { current mode. }\end{array}$ & 215 \\
\hline
\end{tabular}


Table 10. Continuation.......

\begin{tabular}{|c|c|c|c|}
\hline System used & Operation conditions & Observations & Ref. \\
\hline $\begin{array}{l}\text { Simulation } \\
\text { studies }\end{array}$ & $\begin{array}{l}\text { Acetic acid esterifications with five alcohols } \\
\text { (C1-C5) were studied in the presence of acidic } \\
\text { ion-exchange resins (Amberlyst } 15 \text { and Purolite } \\
\text { CT179) Reaction: HAc }+ \text { alcohol = acetate }+ \\
\text { water }\end{array}$ & $\begin{array}{l}\text { Reaction rate expressed in a } \\
\text { Langmuir-Hinshelwood form. Vapor } \\
\text { liquid equilibrium (VLE) and vapor- } \\
\text { liquid-liquid equilibrium (VLLE) } \\
\text { modelled with an NRTL model and } \\
\text { UNIQUAC model for activity } \\
\text { coefficients. }\end{array}$ & 216 \\
\hline $\begin{array}{l}100 \text { mm } \\
\text { diameter column } \\
\text { installed } \\
\text { alternating } \\
\text { dualflow tray } \\
\text { and a catalyst } \\
\text { basket. }\end{array}$ & $\begin{array}{l}\text { Amberlyst } 15 \text { was used as a catalyst for the } \\
\text { esterification reaction of acetic acid with } \\
\text { methanol. }\end{array}$ & $\begin{array}{l}\text { For a feed containing } 2.5 \text { to } 9.9 \text { wt. } \% \\
\text { of acetic acid solution, a recovery of } \\
\text { methyl acetate over } 50 \text { wt. } \% \text { is } \\
\text { possible in the } 1.5 \text { meter high test } \\
\text { column. }\end{array}$ & 217 \\
\hline \multicolumn{4}{|c|}{ Liquid-liquid reactive extractions } \\
\hline $\begin{array}{l}\text { Extraction } \\
\text { conducted in } \\
\text { vials, stirred by } \\
\text { magnetic bar in } \\
\text { water bath at } \\
1000 \mathrm{rpm}, 25{ }^{\circ} \mathrm{C} \\
\text { for } 2 \mathrm{~h} \text {. Followed } \\
\text { by } \\
\text { centrifugation. }\end{array}$ & $\begin{array}{l}\text { Extraction of acetic acid from succinic acid and } \\
\text { from aqueous solutions with tri-n-octylamine } \\
\text { (TOA) dissolved in 1-octanol. Concentration of } \\
\text { TAO in organic phase }(0.25-0.75 \mathrm{~mol} / \mathrm{kg})\end{array}$ & $\begin{array}{l}\text { The removal of acetic acid from } \\
\text { succinic acid aqueous mixtures take } \\
\text { advantage of different degree of } \\
\text { dissociation of each acid with pH. } \\
\text { The equilibrium data of amine-based } \\
\text { extraction was explained by mass } \\
\text { action law. }\end{array}$ & 218 \\
\hline $\begin{array}{l}\text { Continuous } \\
\text { centrifugal } \\
\text { contactor } \\
\text { separator. }\end{array}$ & $\begin{array}{l}\text { Best extraction results obtained with TOA in } 2 \text { - } \\
\text { ethyl-hexanol ( } 40 \text { wt. } \%) \text { and room temperature } \\
\text { with } 84 \% \text { acetic acid recovery at equilibrium } \\
\text { conditions. }\end{array}$ & $\begin{array}{l}\text { Other organic acids (formic acid and } \\
\text { glycolic acid) were also co-extracted } \\
\text { at high efficiencies }\end{array}$ & 16 \\
\hline $\begin{array}{l}20 \mathrm{~mL} \text { vial at } 20 \\
{ }^{\circ} \mathrm{C} \text { and } 500 \mathrm{rpm} \\
\text { for } 22 \mathrm{~h} \text { to } \\
\text { ensure } \\
\text { equilibrium }\end{array}$ & $\begin{array}{l}\text { TOA/2-ethyl-1-hexanol at } 20^{\circ} \mathrm{C} \text {, and } 120 \mathrm{rpm} \\
\text { for } 24 \mathrm{~h} \text {. }\end{array}$ & $\begin{array}{l}\text { Co-extraction of glycoaldehyde and } \\
\text { acetic acid. Mixture of TOA. For a } \\
\text { combined acetic acid and } \\
\text { glucoaldehyde one step extraction } 2- \\
\text { ethyl-1-hexanol gave the best results. } \\
\text { For a two step extraction, a solvent } \\
\text { containing more than } 50 \text { wt. \% TOA } \\
\text { is desired (first acetic acid extracted } \\
\text { followed by glycoaldehyde) }\end{array}$ & 18 \\
\hline
\end{tabular}


Table 10. Continuation........

\begin{tabular}{|c|c|c|c|}
\hline System used & Operation conditions & Observations & Ref. \\
\hline \multicolumn{4}{|c|}{ Extraction with Ionic liquids } \\
\hline $\begin{array}{l}\text { Three } \\
\text { phosphonium } \\
\text { ionic liquids } \\
\text { (ILs), two } \\
\text { imidazolium ILs } \\
\text { and a bench } \\
\text { mark mixture (40 } \\
\begin{array}{l}\text { wt. \% TOA/1- } \\
\text { octanol) }\end{array}\end{array}$ & $\begin{array}{l}\text { Phosphonium ILs showed the highest affinities } \\
\text { for HAc and glycolaldehyde, and reasonable } \\
\text { affinity for acetol. Difficulties to evaporate } \\
\text { oxygenates from phosphonium ILs and the } \\
\text { reactivity of glycoaldehyde with } \mathrm{P}_{666,14}\left[\mathrm{~N}(\mathrm{CN})_{2}\right]\end{array}$ & $\begin{array}{l}\text { Based on the good affinity of } \\
\text { imidazolium ILs for acetol, a two } \\
\text { step extraction process is proposed } \\
\text { where Hmim[B(CN)4 is use to } \\
\text { extract acetol and HAc in the first } \\
\text { step and P666,14 [Phos] may be } \\
\text { applied to extract glycoaldehyde in } \\
\text { the second step. }\end{array}$ & 118 \\
\hline \multicolumn{4}{|c|}{ Nanofiltration and Reverse Osmosis Membranes } \\
\hline $\begin{array}{l}\text { Polymeric } \\
\text { nanofiltration } \\
(\mathrm{NF}) \text { and reverse } \\
\text { osmosis (RO) } \\
\text { membranes }\end{array}$ & $\begin{array}{l}\text { Single solute solutions of acetic acid and } \\
\text { glucose and a model aqueous fraction of bio-oil } \\
\text { containing acetic acid, formic acid, } \\
\text { hydroxyacetone, furfural, guaiacol, catechol and } \\
\text { glucose. Feed pressure: } 40 \text { atm, Temperature: } 21 \\
\pm 1 \text { C. Transmembrane pressures ranging from } \\
5 \text { to } 58 \text { bar. Single solute solutions of } 7 \text { wt. \% } \\
\text { acetic acid and } 15 \text { wt. \% glucose, binary solute } \\
\text { solution of } 7 \text { wt. \% acetic acid and } 15 \text { wt. \% } \\
\text { glucose and a model Aqueous Fraction of Bio- } \\
\text { Oil (AFBO) were used as feed. }\end{array}$ & $\begin{array}{l}\text { At moderate }(\sim 40 \text { bar }) \text { feed } \\
\text { pressures, retention factors of } \\
\text { glucose over } 90 \% \text { and negative } \\
\text { retention factors of acetic acid can be } \\
\text { achieved when using single and } \\
\text { binary aqueous solutions of acetic } \\
\text { acid and glucose. } \\
\text { Fluxes and transmembrane pressure } \\
\text { are linearly related. Presence of } \\
\text { guaiacol irreversibly damaged all the } \\
\text { membranes. }\end{array}$ & 209 \\
\hline $\begin{array}{l}\text { Desal-5 DK NF } \\
\text { membrane (GE- } \\
\text { Osmonics) }\end{array}$ & $\begin{array}{l}\text { A synthetic acetic acid-xylose solution (at the } \\
\text { ratio } 10: 1 \text { ) was used as the model feed. The } \\
\text { solution } \mathrm{pH} \text { was set to } 4.9,6.9 \text { and } 9.1\end{array}$ & $\begin{array}{l}\text { Retention of xylose and acetic acid } \\
\text { was in the range of } 28-81 \% \text { and } \\
-6.8 \%-90 \% \text {, respectively. } \\
\text { Separation factor of } 5.4 \text { was achieved } \\
\text { at pH } 2.9 \text { and } 24.5 \text { bar. }\end{array}$ & 219 \\
\hline
\end{tabular}

\subsection{Methods for Acetol Separation}

Acetol is an important compound that can be obtained from bio-oil. It can be used as precursor of many products such as acrolein, acetone, furan derivatives, propylene glycol, among others ${ }^{220}$. The research on acetol recovery from bio-oil is limited (Table 11 and Figure 8 summarizes the results of our literature review). 
Table 11. Summary of Acetol separation methods

\begin{tabular}{|c|c|c|c|}
\hline System used & Operation conditions & Observations & Ref. \\
\hline $\begin{array}{l}\text { Liquid-liquid } \\
\text { extraction with } \\
3 \text { phosphonium } \\
\text { ionic liquids } \\
\text { (ILs) used as } \\
\text { solvents: two } \\
\text { imidazolium } \\
\text { ILs and one } \\
\text { benchmark } \\
\text { organic mixture } \\
\text { (40 wt. \% tri-n- } \\
\text { octylamine in 1- } \\
\text { octanol: } \\
\text { TOA/1-octanol) }\end{array}$ & $\begin{array}{l}\text { Feed solutions: } 3 \text { single solute solutions }-10 \\
\text { wt. \% acetol, } 10 \text { wt. } \% \text { HAc and } 5 \text { wt. } \% \\
\text { glycolaldehyde solution, respectively }- \text {, and } \\
\text { one mixed solutes solution with } 10 \text { wt. } \% \\
\text { acetol, } 10 \text { wt. } \% \text { HAc and } 5 \text { wt. } \% \\
\text { glycolaldehyde together in milli-Q water. } \\
\text { Extraction was conducted by adding } 2 \mathrm{~g} \text { feed } \\
\text { solution and } 2 \mathrm{~g} \text { solvent in glass vials. The vials } \\
\text { were then introduced in a shaking bath at } 200 \\
\text { rpm at the desired temperatures }(25<\mathrm{T}<60 \mathrm{C}) \\
\text { for } 18 \text { hours. IL regeneration: } \\
\text { Evaporation of single solutes at } 100^{\circ} \mathrm{C} \\
\text { and } 20 \text { mbar, or } 60^{\circ} \mathrm{C} \text { and } 20 \text { mbar for } \\
\text { extraction from mixed solutes. }\end{array}$ & $\begin{array}{l}\text { The lowest extraction efficiency for } \\
\text { acetol was obtained by TOA/1- } \\
\text { octanol, and the highest by the } \\
\text { phosphonium ILs. A two-step } \\
\text { extraction process was proposed } \\
\left.\text { where Hmim[B(CN })_{4}\right] \text { may be used } \\
\text { to extract acetol and HAc in the } \\
\text { first step, and } \mathrm{P}_{666,14}[\mathrm{Phos}] \text { may be } \\
\text { used for glycolaldehyde extraction } \\
\text { in a second step. }\end{array}$ & 118,221 \\
\hline $\begin{array}{l}\text { Aspen } \\
\text { and } \\
\text { Process } \\
\text { Prosen } \\
\text { Economic } \\
\text { Analyzer }\end{array}$ & $\begin{array}{l}\text { Process designed at a capacity of } 200 \mathrm{kt} \\
\text { pyrolysis oil per year, with an operating time of } \\
8000 \mathrm{~h} \text { per year, with extraction, distillation, } \\
\text { and evaporation. }\end{array}$ & $\begin{array}{l}\text { The process simulated can isolate } \\
\text { over } 99 \% \text { of the glycolaldehyde } \\
\text { and acetic acid. Approximately } \\
\text { two-thirds of the acetol in the bio- } \\
\text { oil can be recovered. } \\
\text { All three products had high purity } \\
\text { (over } 98 \text { wt. \%) }\end{array}$ & 19 \\
\hline $\begin{array}{l}\text { Treatment of } \\
\text { distilled phenol } \\
\text { containing } \\
\text { acetol with an } \\
\text { acidic resin at } \\
\text { low temperature } \\
\text { or at elevated } \\
\text { temperature, }\end{array}$ & $\begin{array}{l}\text { A distilled phenol stream containing acetol is } \\
\text { contacted with an acidic resin at about } 85^{\circ} \mathrm{C} \text { or } \\
\text { less. Then phenol is separated from the higher } \\
\text { boiling compounds by distillation (preferably } \\
\text { flash distillation at low pressure). Treatment } \\
\text { times can vary from } 5 \text { minutes to } 1 \text { hour. } \\
\text { Alternatively, the distilled phenol stream } \\
\text { containing acetol can be heated in a closed } \\
\text { system at high temperature, with or without } \\
\text { adding a small amount of caustic. If there's no } \\
\text { addition of caustic, the pH of the stream should } \\
\text { be more than } 2 \text {, if possible above } 2.5 \text {. The } \\
\text { phenol is then separated from the higher boiling } \\
\text { compounds via distillation. The temperatures of } \\
\text { the heat treatment must be at least } 175-225^{\circ} \mathrm{C} \text {. }\end{array}$ & $\begin{array}{l}\text { This patent presents several } \\
\text { examples at different conditions. } \\
700 \text { ppm of acetol was reduced } \\
\text { from phenol stream when the } \\
\text { stream is put in contact with an } \\
\text { acidic resin at about } 85^{\circ} \mathrm{C} \text { for } 15 \\
\text { minutes. In another example, the } \\
\text { content of acetol was reduced from } \\
1036 \text { to less than } 10 \mathrm{ppm} \text { when the } \\
\text { phenol stream containing acetol } \\
\text { was heated to around } 198^{\circ} \mathrm{C} \text { for } 4 \\
\text { hours without caustic addition. }\end{array}$ & 222 \\
\hline
\end{tabular}

\subsection{Methods for Hydroxyacetaldehyde (HHA) Separation}

Hydroxyacetaldehyde, also known as glycolaldehyde, is another important oxygenated present in pyrolysis oil. It is used as food browning agent and as a precursor of ethylene glycol ${ }^{223}$. To produce high yields of hydroxyacetaldehyde materials with low nitrogen content has to be used. Hydroxyacetaldehyde reacts with proteins and amines under typical pyrolysis conditions ${ }^{224}$. In the patent of Stradal and Underwood 224 the authors state that in order to precipitate hydroxyacetaldehyde crystals it is necessary to create an homogeneous solution of water with an 
organic solvent (Methylene chloride) containing at least $2 \mathrm{wt} . \%$ of HHA. This solution needs to be cooled to at least $2{ }^{\circ} \mathrm{C}$ for HHA to precipitate. Special care should be made to avoid heating the HHA Basically the method patented consist an evaporation step under reduced pressure to concentrate the hydroxyacetaldehyde, adding the organic solvent and cooling and separating the hydroxyacetaldehyde from the solution ${ }^{224}$. Table 12 summarizes some of the HHA purification procedures reported in the literature ${ }^{19,118,224-227}$.

Table 12. Summary of glycoaldehyde separation

\begin{tabular}{|c|c|c|c|}
\hline System used & Operation conditions & Observations & Ref. \\
\hline $\begin{array}{l}\text { Liquid-liquid } \\
\text { extraction with } \\
3 \text { phosphonium } \\
\text { ionic liquids } \\
\text { (ILs): two } \\
\text { imidazolium ILs } \\
\text { and one organic } \\
\text { mixture }(40 \mathrm{wt} \\
\% \quad \text { TOA } / 1- \\
\text { octanol) }\end{array}$ & $\begin{array}{l}\text { Feed solutions: } 3 \text { single solute solutions }-10 \text { wt. } \\
\% \text { acetol, } 10 \text { wt. } \% \text { HAc and } 5 \text { wt. \% } \\
\text { glycolaldehyde solution, respectively, and one } \\
\text { mixed solutes solution with } 10 \mathrm{wt} \% \text { acetol, } 10 \mathrm{wt} \text {. } \\
\% \mathrm{HAc} \text { and } 5 \mathrm{wt} \% \text { glycolaldehyde together in } \\
\text { milli-Q water. Temperatures }\left(25<\mathrm{T}<60^{\circ} \mathrm{C}\right) \text { for } \\
18 \text { hours. IL regeneration: Evaporation of single } \\
\text { solutes at } 100^{\circ} \mathrm{C} \text { and } 20 \text { mbar, or } 60^{\circ} \mathrm{C} \text { and } 20 \\
\text { mbar for extraction from mixed solutes. }\end{array}$ & $\begin{array}{l}\text { Phosphonium ILs had the greatest } \\
\text { affinities for HAc and HHA, and } \\
\text { some affinity for acetol. A two-step } \\
\text { extraction process proposed: } \\
\left.\text { Hmim[B(CN })_{4}\right] \text { used to extract } \\
\text { acetol and HAc in the first step, } \\
\mathrm{P}_{666,14}[\mathrm{Phos}] \text { used for } \\
\text { glycolaldehyde extraction in second } \\
\text { step. }\end{array}$ & 118 \\
\hline $\begin{array}{l}\text { Aspen } \text { Plus }^{\circledR} \\
\text { and } \text { Aspen } \\
\text { Process } \\
\text { Economic } \\
\text { Analyzer }\end{array}$ & $\begin{array}{l}\text { Process designed at a capacity of } 200 \mathrm{kt} \text { pyrolysis } \\
\text { oil per year, with an operating time of } 8000 \mathrm{~h} \text { per } \\
\text { year, with extraction, distillation, and evaporation. }\end{array}$ & $\begin{array}{l}\text { Process simulated can isolate over } \\
99 \% \text { of the glycolaldehyde and } \\
\text { acetic acid. Two-thirds of the acetol } \\
\text { in the bio-oil can be recovered. All } \\
\text { three products had high purity (over } \\
98 \text { wt. } \% \text { ). }\end{array}$ & 19 \\
\hline $\begin{array}{l}\text { Rotary } \\
\text { evaporator and } \\
\text { cooler }\end{array}$ & $\begin{array}{l}\text { Vacuum evaporation to remove water and } \\
\text { concentrate hydroxyacetaldehyde. A solution } \\
\text { water, methylene chloride with } 2 \mathrm{wt} \text { \% of HHA is } \\
\text { formed. The HHA is precipitated upon cooling } \\
\text { below } 2{ }^{\circ} \mathrm{C}\end{array}$ & HHA crystals are produced. & 224 \\
\hline $\begin{array}{l}\text { Reactive } \\
\text { extraction of } \\
\text { aldehydes with } \\
\text { primary amine } \\
\text { Primene JM-T }\end{array}$ & $\begin{array}{l}\text { Organic to aqueous volume phase ratio of } 1: 25 \text {. } \\
24 \mathrm{~h} \text { at } 25^{\circ} \mathrm{C} \text { to achieve equilibrium, and then } \\
\text { settle for at least } 2 \text { hours. After that, } 70 \mu 1 \text { samples } \\
\text { of the aqueous phase were collected and mixed } \\
\text { with } 255 \mu 1 \text { of ethanol. }\end{array}$ & $\begin{array}{l}\text { Extraction of Primene JM-T } \\
\text { decreases in the following order: } \\
\text { pentanal }>3 \text {-methylbutanal }> \\
\text { benzaldehyde }>\text { furfural }>2- \\
\text { methyl-2-butenal. Reactive } \\
\text { extraction of HHA with primary } \\
\text { amines is analogous to that of } \\
\text { aldehydes, it is promising in term } \\
\text { of yield and selectivity. }\end{array}$ & 226 \\
\hline
\end{tabular}

\subsection{Method for the separation of fermentable sugars}

Bio-oil contains anhydrosugars — mostly levoglucosan and cellobiosan —, monosaccharides and anhydropolysaccharides ${ }^{228}$. Sugars reported at lower concentrations are fucose, arabinose, galactose, fructose, mannose, xylose, ribose ${ }^{229}$. 
These sugars cause many problems when upgrading the oil through hydrotreatment ${ }^{229}$. Hence, if sugars were removed from bio-oil, it would make the oil hydrotreatment more feasible. Lian et $a l .{ }^{229}$ investigate the isolation, hydrolysis and detoxification of anhydrosugars from pyrolysis oils to produce ethanol and lipids. Ethyl acetate was used for solvent extraction. Two phases were formed, one organic phase, rich in phenolic and furanic, and another aqueous phase, rich in polar compounds such as acetol, acetic acid, and levoglucosan. The aqueous phase was hydrolyzed to produce fermentable sugars and the remaining phenol in the aqueous solution was removed using activated carbon. Besides, $\mathrm{Ba}(\mathrm{OH})_{2}$ was used to neutralize the acids present in the aqueous phase, with a subsequent filtration to remove the precipitate formed.

Rover et al. ${ }^{124}$ investigate the separation between sugars and phenols from the heavy ends of a fractionated condenser system of bio-oil by a simple washing method. They found out that two consecutive washes were more efficient than a single wash, removing over $90 \%$ of the sugars, with 3 to $7 \%$ of impurities. For the detoxification, they concluded that $\mathrm{NaOH}$ overliming was better than liquid-liquid extraction, ionic liquid and ionic resin extraction methods.

\subsection{Methods for the separation of levoglucosan}

Levoglucosan, an anhydrosugar, is one of the main degradation products of cellulose and, therefore, encountered in higher amounts in pyrolysis oils ${ }^{230}$. This concentration is likely to increase if the feedstock is pretreated by acid washing prior the pyrolysis ${ }^{231-234}$. Levoglucosan has the potential of being used in the production of many products, such as resins, plastics, plasticizers, explosives, propellants and surfactants ${ }^{235}$. The U.S. patent $3,309,356^{235}$ introduces a method for separation of levoglucosan in its crystalline form. It's done by a series of solvent extractions. Besides, levoglucosan can also be obtained through extraction with ethyl-acetate or with water extraction of the heavy end bio-oil of a fractionation condensation system.

Bennett et al. ${ }^{230}$ studied the optimal conditions for the separation of levoglucosan through extraction with water. They found the best conditions are $41 \mathrm{wt} . \%$ of water and temperature of $34^{\circ} \mathrm{C}$. This allows a final concentration of levoglucosan up to $88 \mathrm{~g} / \mathrm{L}$ in the aqueous extract. Also, they investigated the optimal conditions for hydrolysis and concluded that at $125^{\circ} \mathrm{C}$, with a residence time of 44 minutes in a solution of $0.5 \mathrm{M} \mathrm{H}_{2} \mathrm{SO}_{4}$ yield to the maximum glucose yield. 
Other patent and work describing the recovery of levoglucosan from pyrolysis oil can be found elsewhere ${ }^{236,237}$. Table 13 and Figure 10 summarizes the main papers published on levoglucosan separation.

Table 13. Summary of levoglucosan separation methods found in the literature

\begin{tabular}{|c|c|c|c|}
\hline System used & Operation conditions & Observations & Ref. \\
\hline $\begin{array}{l}\text { Water } \\
\text { extraction }\end{array}$ & $\begin{array}{l}\text { Water and oil were put in contact in } 50 \mathrm{~mL} \\
\text { Erlenmeyer flasks for } 24 \mathrm{~h} \text { at } 20^{\circ} \mathrm{C} \text { and } 400 \\
\text { rpm. } \\
\text { Water-to-oil mass ratio was } 0.3-0.8 \text { for forest } \\
\text { residue-derived pyrolysis oil, and } 0.4-0.9 \text { for } \\
\text { pine-derived pyrolysis oils. Then the mixture } \\
\text { was let to settle for } 3 \mathrm{~h} \text { for phase separation. }\end{array}$ & $\begin{array}{l}\text { The best water-to-oil ratio for forest } \\
\text { residue-derived pyrolysis oil is } 0.65- \\
0.7 \text {, and for pine-derived pyrolysis oil } \\
\text { is at the lowest possible where } \\
\text { complete phase separation happens. }\end{array}$ & 166 \\
\hline $\begin{array}{l}\text { Simultaneous } \\
\text { esterification } \\
\text { and acetylation } \\
\text { with online } \\
\text { solvent } \\
\text { extraction } \\
\text { (SEAWOSE) in } \\
\text { butanol. }\end{array}$ & $\begin{array}{l}\text { Approximately } 30 \mathrm{~g} \text { of aqueous fraction was } \\
\text { added into the water knockout trap, while } 80 \mathrm{~g} \\
\text { of butanol and } 1 \mathrm{~g} \text { of sulfuric acid ( } 98 \mathrm{wt} . \% \text { ) } \\
\text { were added to the four-necked bottom flask. } \\
\text { The temperature in the water knockout trap was } \\
\text { about } 110^{\circ} \mathrm{C} \text {. }\end{array}$ & $\begin{array}{l}\text { All aqueous fraction samples had very } \\
\text { high saccharide conversions (over } \\
92 \% \text { ). Therefore, with online } \\
\text { extraction, the saccharides could be } \\
\text { converted into the upgraded oil. }\end{array}$ & 238 \\
\hline
\end{tabular}

\subsection{Methods for the separation of Mono and Oligo-phenols}

Phenols can be used in a wide range of applications: intermediates in the synthesis of pharmaceuticals, raw materials for production of phenol formaldehyde resins, antioxidants, gasoline additives, food additives, polymerization initiators, pesticides, and colorants ${ }^{239}$. Therefore, it is of great interest to efficiently extract the phenols from lignin pyrolysis oil. There are many separation strategies on literature involving phenol separation. Table 14 shows a summary of the methods described in the literature to separate mono and oligo-phenols The reader can find other phenol separations techniques elsewhere ${ }^{152,174,176,240-248}$. 
Table 14. Summary of mono and oligo-phenols separation

\begin{tabular}{|c|c|c|c|}
\hline System used & Operation conditions & Observations & Ref. \\
\hline $\begin{array}{l}\text { Sepabeads resin } \\
\text { SP207 } \\
\text { (Mitsubishi } \\
\text { Chemical) and } \\
\text { Amberlite } \\
\text { XAD4 resin } \\
\text { (Rohm and } \\
\text { Haas) }\end{array}$ & $\begin{array}{l}\text { Equilibrium adsorption was performed at } 22 \\
{ }^{\circ} \mathrm{C} \text {. Over } 98 \% \text { of the phenolic species in the } \\
\text { sugar fraction } 1 \text { (SF1) were removed by } \\
\text { running SF1 solution over SP207 resin. }\end{array}$ & $\begin{array}{l}\text { The adsorption capability for phenolic } \\
\text { species of both polymeric resins is } \\
\text { greater than for levoglucosan when a } \\
\text { mixture of sugars and phenolic species } \\
\text { is used as the applied solution. }\end{array}$ & 189 \\
\hline $\begin{array}{l}\text { Batch steam } \\
\text { distillation, } \\
\text { followed by } \\
\text { fractional } \\
\text { vacuum } \\
\text { distillation and } \\
\text { a series of } \\
\text { liquid-liquid } \\
\text { extractions. }\end{array}$ & $\begin{array}{l}\text { Steam injected at } 100^{\circ} \mathrm{C} .100 \mathrm{~g} \text { of the bio-oil } \\
\text { was kept at } 130^{\circ} \mathrm{C} \text { in a mineral oil bath during } \\
\text { the distillation. The distillate obtained at a } \\
\text { temperature of } 105^{\circ} \mathrm{C} \text { was condensed, } \\
\text { collected, and then decanted. The aqueous } \\
\text { phase was extracted with ethyl acetate. The } \\
\text { solvent was evaporated under vacuum at } 30^{\circ} \mathrm{C} \text {, } \\
\text { and this oil further distilled under } 0.67 \mathrm{kPa} \text {, at } \\
\text { temperature up to } 135^{\circ} \mathrm{C} \text {. Fraction from } \\
\text { vacuum distillation was liquid-liquid extracted } \\
\text { to obtain a syringol-rich fraction. }\end{array}$ & $\begin{array}{l}88.2 \% \text { of the total phenols in the bio-oil } \\
\text { are recovered by steam distillation with } \\
\text { a steam-to-pyrolytic oil ratio of } 27 . \text { The } \\
\text { successive extractions of the syringol- } \\
\text { concentrated fraction using pentane and } \\
\text { water yielded high purity syringol } \\
(92.3 \% \text { purity). }\end{array}$ & 176 \\
\hline $\begin{array}{l}\text { Multi-step } \\
\text { separation } \\
\text { procedure }\end{array}$ & $\begin{array}{l}30 \mathrm{~g} \text { of bio-oil mixed with } 30 \mathrm{~mL} \text { of deionized } \\
\text { water. } 2.5 \mathrm{~mol} / \mathrm{L} \mathrm{NaOH} \text { solution was used to } \\
\text { dissolve the water insoluble phase under } \\
\text { ultrasonication, at } \mathrm{pH} 14 \text { followed by an } \\
\text { extraction with } \mathrm{CH}_{2} \mathrm{Cl}_{2} \text { to obtain neutral } \\
\text { macromolecules. The } \mathrm{CH}_{2} \mathrm{Cl}_{2} \text {-insoluble } \\
\text { alkaline solution was then acidified to } \mathrm{pH} 6.4 \\
\text { with } \mathrm{HCl} \text {. Through filtration, the precipitate } \\
\text { was collected and then dried at } 40^{\circ} \mathrm{C} \text {. This } \\
\text { precipitated was called high-molecular-weight } \\
\text { pyrolytic lignin (HMWPL). The chemicals } \\
\text { from the acidic solution were recovered by } \\
\text { extraction with } 100 \mathrm{~mL} \text { of } \mathrm{CH}_{2} \mathrm{Cl}_{2} \text {. The } \\
\text { precipitate was named low-molecular-weight } \\
\text { pyrolytic lignin (LMWPL). }\end{array}$ & $\begin{array}{l}\text { There was a predomination of polymers } \\
\text { with high molecular weight in } \\
\text { HMWPL. In LMWPL, the predominant } \\
\text { groups were reactive phenolic hydroxyl } \\
\text { groups. } \\
\text { Overall, the relative contents of total } \\
\text { phenolic molecules in fractions B and C } \\
\text { summed } 94.35 \% \text { and } 54.33 \% \text {, } \\
\text { respectively. }\end{array}$ & 152 \\
\hline $\begin{array}{l}\text { Vacuum } \\
\text { distillation } \\
\text { followed by } \\
\text { batch liquid- } \\
\text { liquid } \\
\text { extraction }\end{array}$ & $\begin{array}{l}\text { Vacuum distillation: } 0.40 \mathrm{kPa} \text {, temperatures: } \\
230,190 \text { and } 160^{\circ} \mathrm{C} \text {. Volatiles condensed at } \\
\text { room temperature, } 0^{\circ} \mathrm{C},-60^{\circ} \mathrm{C} \text { and }-70^{\circ} \mathrm{C} \text {. } \\
\text { Liquid-liquid extraction: Oil phase obtained at } \\
160^{\circ} \mathrm{C} \text { was dissolved in ethyl acetate }(1: 1 \\
\text { weight ratio). Phenols were converted to } \\
\text { phenolate ions by the addition of an alkaline } \\
\text { solution. A sulfuric acid solution ( } 50 \mathrm{wt} \text {. } \%) \\
\text { was added into the aqueous phase till } \mathrm{pH} 6 \text { to } \\
\text { regenerate the phenols. Phenols are extracted } \\
\text { with ethyl acetate }\end{array}$ & $\begin{array}{l}\text { Complete extraction of catechol was } \\
\text { achieved at a } \mathrm{pH} \text { of } 11.3 \text { after three } \\
\text { stages. The other phenols required five } \\
\text { stages. The lower the } \mathrm{pH} \text {, the harder the } \\
\text { phenol extraction. At } \mathrm{pH} 9.5 \text {, no phenol } \\
\text { was completely extracted from the } \\
\text { primary oil. }\end{array}$ & 174 \\
\hline
\end{tabular}


Table 14. Conclusions.......

\begin{tabular}{|c|c|c|c|}
\hline System used & Operation conditions & Observations & Ref. \\
\hline $\begin{array}{l}\text { Batch aqueous } \\
\text { extraction and } \\
\text { batch solvent- } \\
\text { anti-solvent } \\
\text { extraction }\end{array}$ & $\begin{array}{l}\text { Room temperature }\left(23^{\circ} \mathrm{C}\right) \text {. Phase mass ratio of } \\
\text { solvent to feed: } 1: 2.35 \text { up to } 2: 1 \text { for water } \\
\text { extraction Solvent was removed by } \\
\text { evaporation. In aqueous extraction, water, } \\
\text { aqueous } \mathrm{NaHSO}_{3} \text { and alkali solution were } \\
\text { tested as solvents. For the solvent-anti-solvent } \\
\text { technique, a simultaneous addition of an } \\
\text { hydrophobic-polar solvent (e.g. MIBK, } \\
\text { toluene, isopropyl ether, ethyl acetate) and } \\
\text { either water, aqueous NaHSO} 3 \text { or alkali } \\
\text { solution was used. }\end{array}$ & $\begin{array}{l}\text { Catechol and vanillin had the highest } \\
\text { distribution coefficients. Among the } \\
\text { aqueous extraction, alkali extraction } \\
\text { was the most efficient for phenols } \\
\text { recovery. Among the solvent-anti- } \\
\text { solvent technique, MIBK is the most } \\
\text { effective solvent in combination with } \\
\mathrm{NaOH} \text { aqueous solution. }\end{array}$ & 240 \\
\hline $\begin{array}{l}\text { Small scale } \\
\text { extraction with } \\
\text { switchable } \\
\text { hydrophilicity } \\
\text { solvents (SHS) }\end{array}$ & $\begin{array}{l}10 \mathrm{~g} \text { of pyrolysis oil was mixed with } 100 \mathrm{~mL} \\
\text { of } \mathrm{N} \text {, N-dimethylcyclohexylamine. The mixture } \\
\text { was centrifuged and the insoluble components } \\
\text { were removed. The acids from the solution } \\
\text { were removed with } 50 \mathrm{~mL} \text { of } \mathrm{NaHCO}_{3} \text {, after } \\
\text { what the remaining amine solution was mixed } \\
\text { with distilled water. The mixture was bubbled } \\
\text { with } \mathrm{CO}_{2} \text { magnetic stirred for approximately } 3 \\
\text { hours until the amine layer and the water layer } \\
\text { combined into one single phase. After that, a } \\
\text { low-polarity portion of the oil (Fraction \#2) } \\
\text { detached from the solution, and phenols stayed } \\
\text { in the ammonium bicarbonate phase. Ethyl } \\
\text { acetate (EtOAc, } 6 \text { x } 100 \text { mL) was used for } \\
\text { phenol extraction. Then this EtOAc solution } \\
\text { with phenols was washed sequentially with } \\
\mathrm{HCl} \text { solution to eliminate residual amine, and } \\
\text { with saturated NaCl to remove moisture. The } \\
\text { solvent was removed by rotary evaporation, } \\
\text { leaving the phenols extract (Fraction \#3). The } \\
\text { fraction was bubbled with } \mathrm{N}_{2} \text { at } 60^{\circ} \mathrm{C} \text { to switch } \\
\text { the amine in the solution back to its neutral } \\
\text { form. }\end{array}$ & $\begin{array}{l}\text { Phenols were efficiently extracted }(72 \% \\
\text { of guaiacol, } 70 \% \text { of } 4 \text {-methylguaiacol } \\
\text { and } 82 \% \text { of } 3 \text {-methyl-4-ethylphenol). } \\
\text { Overall, } 91 \% \text { of the solvent SHS was } \\
\text { recovered and can be reused for next } \\
\text { extraction. }\end{array}$ & 247 \\
\hline $\begin{array}{l}\text { SG-packed } \\
\text { column }\end{array}$ & $\begin{array}{l}\text { A series of extractions were conducted to yield } \\
\left.3 \text { extracts from bio-oil: } E_{I}, E_{I} \text { and } E_{I I}\right) \text {. Solvent } \\
\text { was used to dissolve the sample followed by } \\
\text { solution mixing with } 0.5 \mathrm{~g} \text { of silica gel (SG). }\end{array}$ & $\begin{array}{l}71.2 \% \text { of acetophenone was isolated } \\
\text { into } \mathrm{ES}_{\mathrm{a} 1}, 55.6 \% \text { of catechol was } \\
\text { isolated into } \mathrm{ES}_{\mathrm{a} 2}, 95.7 \% \text { of guaiacols } \\
\text { into } \mathrm{ES}_{\mathrm{a} 2}, 57.2 \% \text { of syringol into } \mathrm{ES}_{\mathrm{c} 3} \text {, } \\
\text { and } 52.6 \% \text { of hydroxycyclopentanones } \\
\text { into } \mathrm{ES}_{\mathrm{c} 4} \text {. }\end{array}$ & 241 \\
\hline
\end{tabular}




\section{Biofuels Production}

Bio-oil can be potentially directly used as fuel in burner/furnace and burner/boiler systems, in medium- and slow-speed diesel engines, gas turbines and Stirling engines. However, bio-oils are very corrosive ${ }^{250}$, show low thermal stability and low heating value. All these properties hinder their storage and direct use as liquid fuel ${ }^{2,26}$. Therefore, an upgrading process becomes necessary before their use as transportation fuels ${ }^{251}$. The most common upgrading strategies reported in the literature are: production of micro-emulsions ${ }^{252-257}$, extraction of fractions with bio-diesel ${ }^{24,258}$, blending with solvents ${ }^{99}, 146,259-261$, acetalization and esterification ${ }^{78,165,262-268}$, calcium enriched bio-oil ${ }^{47,269}$, co-processing in FCC units ${ }^{88-92}$, co-processing in hydrotreating units ${ }^{72,93,94,96,97 .}$

Emulsions: Bio-oil can't be directly added to hydrocarbons fuels because they are immiscible. The high amount of water in the bio-oil is responsible for the formation of a separated phase when blending bio-oil with another fuel. This problem is addressed by using surfactants to form emulsions of bio-oil with the fuel ${ }^{251}$. Because emulsion is a mixture of fuels with different characteristics, the final properties will be flanked by the properties of the separated fuels ${ }^{270}$. The cost and energy consumption for emulsions production cannot be disregarded ${ }^{257}$.

Lin et al. ${ }^{271}$ investigated three different emulsifiers (Span 80, Tween 80 and Atlox 4914). Among these three, Atlox 4914 showed the best performance. Moreover, they found that the optimum hydrophilic-lipophilic balance, an important parameter for choosing an emulsifier, is directly proportional to the atomic $\mathrm{O} / \mathrm{C}$ or $\mathrm{H} / \mathrm{C}$ ratio, water content and inversely proportional to the high heating value of bio-oil. Other studies on the production of emulsions of bio-oil with diesel can be found elsewhere $252,253,256,272-275$.

Mixtures of bio-oils with other fuels: Bio-oils can be used in boilers and engines when blended to conventional fuels $^{276}$. It has been showed that mixtures of bio-oil and alcohols, for instance, improve fuel properties ${ }^{146,277}$. Blending bio-oil with methanol and tetraethylene-glycol dinitrate, a cetane-improving compound, was showed to make bio-oil suitable to use in high speed diesel engines $^{47}$.

Zhang and $\mathrm{Wu}^{278}$ addressed the limitation of blending glycerol with bio-oil by using only the water soluble fraction (WSF) of the oil. This alternative mixture increased the blend rate up to 
$100 \%$. Besides, the blends between glycerol and the WSF decreased the acidity and water contents, while increasing the density and heating values of the WSF. Finally, they found that adding biochar to this mixture improved even more properties of WSF. Further studies on mixtures of bio-oil and other fuels are available in the literature $258,279-281$.

Bio-oil esterification: Bio-oil esterification is another strategy extensively studied to improve bio-oil fuel properties. Table 15 summarizes the studies on bio-oil esterification reported in the literature.

Table 15. Summary bio-oil esterification studies reported in the literature

\begin{tabular}{|c|c|c|c|}
\hline System used & Operation conditions & Observations & Ref. \\
\hline $\begin{array}{l}130 \mathrm{~mL} \\
\text { Hastelloy } \\
\text { batch } \\
\text { autoclave } \\
\text { reactor }\end{array}$ & $\begin{array}{l}\text { Reaction mixture composed by a methanol: } \\
\text { bio-oil ratio of } 0.9: 1 \text {; Solid acid catalyst ( } 1,3 \text { or } \\
6 \text { wt. } \% \text { of total mixture); } 700 \text { rpm stirring rate; } \\
\text { reaction temperature ranging from } 70 \text { to } 170 \\
{ }^{\circ} \mathrm{C} \text {; nitrogen atmosphere. }\end{array}$ & $\begin{array}{l}\text { Either the increase in temperature, reaction } \\
\text { time or catalyst loading lead to a higher } \\
\text { conversion of light organic acids and } \\
\text { aldehydes to esters and acetals. At } \\
\text { temperatures over } 110{ }^{\circ} \mathrm{C} \text { and catalyst } \\
\text { loading above } 6 \mathrm{wt} \% \text {, there could be } \\
\text { further decomposition of certain acetals. }\end{array}$ & 282 \\
\hline $\begin{array}{l}100 \quad \mathrm{~mL} \\
\text { stainless } \\
\text { steel } \\
\text { autoclave }\end{array}$ & $\begin{array}{l}\text { Nitrogen atmosphere, reaction temperature } 200 \\
\text { and } 250^{\circ} \mathrm{C}, 7 \mathrm{MPa}, 500 \mathrm{rpm} \text { stirring rate, for } \\
30-180 \mathrm{~min} \text {. Different ethanol:bio-oil ratios } \\
(1: 1,3: 1,5: 1,10: 1)\end{array}$ & $\begin{array}{l}\text { At } 250^{\circ} \mathrm{C} \text { and } 7 \mathrm{MPa} \text {, there was a complete } \\
\text { transferal of carboxylic acids in the } \\
\text { supercritical ethanol system. Selectivity of } \\
\text { ethyl acetate reached } 100 \% \text { at the } \\
\text { ethanol/bio-oil ratio of } 5: 1 .\end{array}$ & 283 \\
\hline $\begin{array}{l}\text { Fixed-bed } \\
\text { reactor with } \\
\text { an HZSM-5 } \\
\text { catalyst } \\
(\mathrm{Si} / \mathrm{Al} 1 / 425)\end{array}$ & $\begin{array}{l}3 \text { groups of reactants: Group A ( } 50 \text { wt. } \% \text { acetic } \\
\text { acid and } 50 \text { wt. } \% \text { deionized water), group B } \\
\text { ( } 50 \text { wt. } \% \text { propanoic acid and } 50 \text { wt. } \% \text { water }) \text {, } \\
\text { and group } \mathrm{C}(25 \text { wt. } \% \text { acetic acid, } 25 \text { wt. } \% \\
\text { propanoic acid and } 50 \text { wt. } \% \text { deionized water). } \\
\text { Reaction at } 330^{\circ} \mathrm{C}, 2 \mathrm{~h} \text { reaction time. }\end{array}$ & $\begin{array}{l}\text { Conversion degree of acetic acid was } \\
\text { lower than propanoic acid. Selectivity for } \\
\text { acetic acid increased up to } 52 \% \text { by } \\
\text { increasing the Liquid Hourly Space } \\
\text { Velocity (LHSV) to } 3 \mathrm{~h}^{-1} \text {. Selectivity for } \\
\text { propanoic acid at LSHV=3 } \mathrm{h}^{-1} \text { was as high } \\
\text { as } 80 \% \text {. }\end{array}$ & 284 \\
\hline $\begin{array}{l}\text { Round } \\
\text { bottom flask } \\
\text { in a heating } \\
\text { mantle for } \\
\text { the reactions } \\
\text { under } \\
\text { azeotropic } \\
\text { water } \\
\text { removal and } \\
\text { the reactive } \\
\text { distillation. }\end{array}$ & $\begin{array}{l}\text { Sulfuric acid was used as catalyst. } \mathrm{CaOH}_{2} \text { was } \\
\text { added to neutralize the strong acid after the } \\
\text { reaction, causing precipitation of calcium } \\
\text { sulfate that was then filtered off and washed } \\
\text { using methanol. Reactions of bio-oil with } \\
\text { alcohols under azeotropic water removal: P- } \\
\text { toluenesulfonic acid or Amberlyst-15 were } \\
\text { used as catalyst. } 81^{\circ} \mathrm{C} \text {, continuous addition of } \\
\text { cyclohexane. }\end{array}$ & $\begin{array}{l}\text { High water content in crude bio-oils } \\
\text { creates equilibrium limitations in } \\
\text { condensation reactions. It wasn't possible } \\
\text { to decrease the acid number to a value } \\
\text { acceptable by petroleum refinery } \\
\text { standards. }\end{array}$ & 264 \\
\hline \begin{tabular}{l}
\multicolumn{2}{l}{ Custom- } \\
built, stirred \\
SUS 316 \\
reactor with \\
an inner \\
volume of \\
$140 \mathrm{~mL}$ \\
\end{tabular} & $\begin{array}{l}\text { Nitrogen atmosphere. } 1 \mathrm{MPa}, 500 \mathrm{rpm} \text { stirring } \\
\text { rate, heating rate of } 15^{\circ} \mathrm{C} / \mathrm{min} \text {, various } \\
\text { temperatures }\left(300,350 \text { and } 400^{\circ} \mathrm{C}\right) \text {. The } \\
\text { produced gas was purged. Liquid and solid } \\
\text { products were collected in a beaker and } \\
\text { separated through vacuum filtration. }\end{array}$ & $\begin{array}{l}\text { The supercritical ethanol-based upgrading } \\
\text { lead to reduced acid number (TAN) and } \\
\text { water/oxygen contents. The yield of the } \\
\text { upgraded oil was over } 80 \text { wt. } \% \text {. }\end{array}$ & 285 \\
\hline
\end{tabular}


Table 15. Continuation......

\begin{tabular}{|c|c|c|c|}
\hline System used & Operation conditions & Observations & Ref. \\
\hline $\begin{array}{lr}\text { Batch } & \text { glass } \\
\text { reactor } & \\
\text { equipped } & \text { with a } \\
200-\text {-rpm } & \text { mixer } \\
\text { for } & \text { ozone } \\
\text { oxidation } & \text { of } \\
\text { bio-oil. } & \end{array}$ & $\begin{array}{l}\text { Ozone oxidation of bio-oil: Continuous } \\
\text { introduction of ozone into the reactor. } 20 \pm 2^{\circ} \mathrm{C} \text {, } \\
10 \mathrm{~h} \text { reaction time. Reactions of Bio-Oil with } \\
\text { Alcohols under Azeotropic Water Removal: } \\
50 \mathrm{~g} \text { oxidized bio-oil, } 50 \mathrm{~g} \text { of butanol, and } 4 \mathrm{~g} \text { of } \\
\text { catalyst }\left(\mathrm{NaHSO}_{4}\right) \text {. Temperature maintained at } \\
116^{\circ} \mathrm{C} \text {. The distillate was a two phase liquid. } \\
\text { The upper layer (mostly butanol) was returned } \\
\text { to the flask, and the lower aqueous layer } \\
\text { collected separately. }\end{array}$ & $\begin{array}{l}\text { Acid number of bio-oil was improved, } \\
\text { changing from } 45.4 \text { to } 118.4 \mathrm{mg} \\
\mathrm{KOH} / \mathrm{g} \text { after oxidation. } \\
\text { Oxidation also increased the thermal } \\
\text { stability in esterification of bio-oil. } \\
\text { The oxidized bio-oil had similar } \\
\text { molecular weight distribution as the } \\
\text { original one. Highest molecular weight } \\
\text { of around } 19000 \text { obtained after direct } \\
\text { esterification. }\end{array}$ & 286 \\
\hline $\begin{array}{l}25 \mathrm{~mL} \text { round- } \\
\text { bottom flask } \\
\text { fitted with a } \\
\text { condenser and a } \\
\text { magnetic stirrer }\end{array}$ & $\begin{array}{l}\text { A dicationic ionic liquid } \mathrm{C}_{6}(\mathrm{mim})_{2}-\mathrm{HSO}_{4} \text { used } \\
\text { as catalyst. Typical procedure of Fischer } \\
\text { Esterification over } \mathrm{C}_{6}(\mathrm{mim})_{2}-\mathrm{HSO}_{4} \text { Catalysts: } \\
\text { Acetic acid, ethanol, and ionic liquid placed } \\
\text { under vigorous stirring, at room temperature for } \\
0.5-6 \mathrm{~h} \text {. Esterification of Bio-oil with Alcohol } \\
\text { over IL Catalysts: Bio-oil, ethanol, and ionic } \\
\text { liquid, at room temperature for } 6 \mathrm{~h} \text {. After the } \\
\text { reaction was complete, the ester and ionic liquid } \\
\mathrm{C}_{6}(\mathrm{mim})_{2}-\mathrm{HSO}_{4} \text { were separated by decanting. }\end{array}$ & $\begin{array}{l}\text { The upgraded bio-oil had a yield of } \\
\text { about } 48 \% \text {, and was composed of } \\
\text { esters and other low polar components. } \\
\text { The upgraded bio-oil had significant } \\
\text { better properties compared to the crude } \\
\text { bio-oil, as it had less water and acid } \\
\text { content. }\end{array}$ & 287 \\
\hline $\begin{array}{l}130 \mathrm{~mL} \text { batch } \\
\text { reactor }\end{array}$ & $\begin{array}{l}\text { Reaction mixture composed of methanol and } \\
\text { bio-oil at different mass ratios. Acid catalyst } \\
\text { Amberlyst- } 70 \text {. Nitrogen atmosphere, } 700 \mathrm{rpm} \\
\text { stirring rate, } 120 \text { min reaction time. Various } \\
\text { temperatures }\left(70-170^{\circ} \mathrm{C}\right) \text {. }\end{array}$ & $\begin{array}{l}\text { Simultaneous formation of } \\
\text { levoglucosan from the hydrolysis of } \\
\text { sugar oligomers and esterification of } \\
\text { organic acids to esters occurred. } \\
\text { Glycosidation also occurs because } \\
\text { levoglucosan is further hydrolyzed into } \\
\text { D-glucose, which reacts with methanol } \\
\text { producing methyl-a-D- } \\
\text { glucopyranoside. Reactions dependent } \\
\text { on the catalyst loading and the } \\
\text { methanol/bio-oil ratio. }\end{array}$ & 262 \\
\hline
\end{tabular}

\section{Bio-Products}

In this section we will review existing and potential co-products that can be obtained from the whole bio-oil, its water soluble and insoluble fractions and the main products that can be derived from pyrolysis oils.

Bio-lime: The reaction between bio-oil phenols and the carboxylic acids and lime produce calcium salts that can be applied for the adsorption of acid gas compounds, like $\mathrm{SO}_{\mathrm{x}}{ }^{288}$. This product, named BioLime by Dynamotive Corporation, increases the efficiency in capturing acid gases $\left(\mathrm{SO}_{\mathrm{x}}\right)$ emitted from coal combustors, compared to lime ${ }^{288}$. 
Slow release nitrogen fertilizers: Amides, imines and Mannich reaction products, are produced from the reaction of bio-oil functional groups (carbonyl, carboxyl, hydroxyl, phenolic and methoxyl) with ammonia, urea, and other amino compounds and can function as slow release organic fertilizers with $10 \%$ of nitrogen ${ }^{266,308}$. Fertilizers produced with this method have a lower leachability compared to mineral fertilizers, obtaining then a slow-release nitrogen fertilizer, and thus resulting in less pollution of the groundwater than mineral fertilizers ${ }^{266}$. Typical fertilizer with controlled nitrogen release sells for around \$250-1,250 ton ${ }^{-1} 266$.

Pesticides and wood preservatives: The development of pesticides from tobacco leaves and dried coffee grounds bio-oil against problematic pests in Canadian agriculture has been studied at the University of Western Ontario ${ }^{294,295}$. Converting tobacco leaves to natural pesticides in the form of bio-oil can be done since tobacco's pesticide properties are well-known ${ }^{295}$. Studies of whole bio-oils and their lignin-rich fractions as potential environmentally friendly wood preservatives have been performed with hopes to replace the metal-based CCA and copper systems that have raised environmental concerns ${ }^{290}$. The lignin-rich fractions showed greater fungal inhibition than whole bio-oils. The synergistic fungicidal properties of bio-oils as a potential substitute for creosote, which also presents environmental concerns, have been demonstrated by several researchers ${ }^{293}$. Pentachlorophenol has been proven to be 10 times more effective with bio-oil ${ }^{290}$. Bio-oil can be used as a green wood preservative due to some terpenoid and phenolic compounds that act as insecticides and fungicides ${ }^{291,292}$. Mohan et al. ${ }^{290}$ had some success in initial tests of a polymerization chemical to prevent leaching. Table 16 summarizes some of the studies so far conducted in the use of bio-oil as pesticide in agriculture or as wood preservative. 
Table 16. Application of pyrolysis oil fractions in agriculture and as wood preservative

\begin{tabular}{|c|c|c|c|}
\hline Source and fraction used & Application & Observation & Ref. \\
\hline $\begin{array}{l}\text { Whole bio-oil from coffee } \\
\text { grounds and fractions } \\
\text { obtained by liquid-liquid } \\
\text { extractions }\end{array}$ & $\begin{array}{l}\text { Insecticide (against Colorado } \\
\text { Potato Beetle - Leptinotarsa } \\
\text { decemlineata Say) and } \\
\text { bactericide (against bacteria } S \text {. } \\
\text { scabies and C. michiganensis) }\end{array}$ & $\begin{array}{l}\text { They showed good insecticide and } \\
\text { bactericide effects }\end{array}$ & 294 \\
\hline $\begin{array}{l}\text { Bio-oil from tobacco } \\
\text { leaves and fractions } \\
\text { obtained by liquid-liquid } \\
\text { extractions }\end{array}$ & $\begin{array}{l}\text { Insecticide (against Colorado } \\
\text { Potato Beetle - Leptinotarsa } \\
\text { decemlineata), fungicide } \\
\text { (against Pythium ultimum) and } \\
\text { bactericiderragainst } \\
\text { Streptomyces scabies and } \\
\text { ClaVibacter michiganensis) }\end{array}$ & $\begin{array}{l}\text { The Colorado Potato Beetle, Streptomyces } \\
\text { scabies, ClaVibacter michiganensis, and } \\
\text { Pythium ultimum were all strongly affected } \\
\text { by tobacco bio-oils. Good insecticide effect } \\
\text { was also observed by the nicotine-free } \\
\text { fractions of the tobacco bio-oil, along with } \\
\text { inhibited growth for the microorganisms. }\end{array}$ & 295 \\
\hline $\begin{array}{lr}\text { Wood vinegar } & \text { obtained } \\
\text { from the } & \text { Gangwon } \\
\text { Mokcho } & \text { Industry } \\
\text { Incorporation, } & \text { Yeongwol, } \\
\text { Korea } & \end{array}$ & $\begin{array}{l}\text { Insecticide (against } N . \text { lugens } \\
\text { and } L \text {. striatellus) }\end{array}$ & $\begin{array}{l}\text { When mixed with carbosulfan (an } \\
\text { insecticide), wood vinegar enhanced its } \\
\text { insecticidal effect. Used alone, wood vinegar } \\
\text { had no insecticidal activity. Mixed with other } \\
\text { insecticides, wood vinegar had no effect. }\end{array}$ & 296 \\
\hline $\begin{array}{l}\text { Wood vinegars from } \\
\text { coconut shell (wood } \\
\text { vinegar A), coconut shell } \\
\text { and coir } 1: 1 \mathrm{w} / \mathrm{w} \text { (wood } \\
\text { vinegar B) }\end{array}$ & $\begin{array}{l}\text { Termiticide } \quad \text { (against } \\
\text { Odontotermes } s p \text { ) and pesticide } \\
\text { (against Ferrisia virgate) }\end{array}$ & $\begin{array}{l}\text { Highest termiticidal activity at a dilution of } \\
1: 50 \mathrm{v} / \mathrm{v} \text {, wood vinegar: sterile water, killing } \\
\text { more than } 80 \% \text { of termite workers after the } \\
24 \mathrm{~h} \text {. Over } 95 \% \text { of striped mealy bugs were } \\
\text { killed by wood vinegars A and B at a dilution } \\
\text { of } 1: 10 \text {. }\end{array}$ & 297 \\
\hline
\end{tabular}


Table 16. Continuation.......

\begin{tabular}{|c|c|c|c|}
\hline Source and fraction used & Application & Observation & Ref. \\
\hline $\begin{array}{l}\text { Wood vinegar from Vitex } \\
\text { pubescens at different } \\
\text { temperatures }\end{array}$ & $\begin{array}{lr}\text { Fungicide } & \text { (against } \\
\text { Trametes versicolor and } \\
\text { Fomitopsis palustris) and } \\
\text { termiticide } r \quad \text { (against } \\
\text { Reticulitermes } & \text { speratus } \\
\text { and } & \text { Coptotermes } \\
\text { formosanus) } & \end{array}$ & $\begin{array}{l}\text { Demontrated antifungal activity against Trametes } \\
\text { versicolor and Fomitopsis palustris. Better } \\
\text { performance obtained by wood vinegars produced } \\
\text { at } 450^{\circ} \mathrm{C} \text {. Showed antitermite activity to both } \\
\text { termites in the no-choice experiment. In the } \\
\text { direct-choice experiment, wood vinegar showed } \\
\text { great repellent effect. }\end{array}$ & 298 \\
\hline $\begin{array}{l}\text { Wood vinegar produced } \\
\text { from fresh wood in a } \\
\text { Iwate kiln }\end{array}$ & $\begin{array}{l}\text { Add-on to bio-fertilizer to } \\
\text { increase yields and reduce } \\
\text { pest infestations on } \\
\text { soybean. Six different } \\
\text { treatments were tested } \\
\text { comparing the effect of } \\
\text { wood vinegar with } \\
\text { mixtures of well-known } \\
\text { insect repellent and } \\
\text { pesticide like tobacco, } \\
\text { citronella or derris }\end{array}$ & $\begin{array}{l}\text { Average soybean yields of } 402 \mathrm{~kg} / \mathrm{rai} \text { were } \\
\text { obtained and the yields didn't statistically differ } \\
\text { among treatments. The wood vinegar treatment } \\
\text { showed the most significant pest control } \\
\text { efficiency with an insect damage score of } 1.75 \\
\text { compared to } 3.29 \text { for the } 5 \text { other treatments }\end{array}$ & 299 \\
\hline $\begin{array}{l}\text { Wood vinegar produced } \\
\text { by burning fresh wood at } \\
120-430^{\circ} \mathrm{C} \text { in a charcoal } \\
\text { kiln. Also, extracts from } \\
\text { three of the medicinal } \\
\text { plants: neem seed } \\
\text { (Azadirachta indica A. } \\
\text { Juss) and yam bean seed } \\
\text { Pachyrhizus erosus } \\
\text { extracts and citronella } \\
\text { grass (Cymbopogon } \\
\text { nardus) }\end{array}$ & $\begin{array}{l}\text { Insecticide (against larvae } \\
\text { of mosquito Culex } \\
\text { quinquefasciatus Say }\end{array}$ & $\begin{array}{l}\text { Using the dropping method, wood vinegar at } 2 \% \\
\text { concentration could kill } 73.75 \% \text { of mosquito } \\
\text { larvae after } 24 \mathrm{~h} \text {, and over } 96 \% \text { after } 72 \mathrm{~h} \text { of test. } \\
\text { Using the topical application method, wood } \\
\text { vinegar at } 20 \% \text { concentration could kill a } \\
\text { maximum of } 15 \% \text { of mosquito larvae after } 72 \mathrm{~h} \\
\text { of test. Mixed with extract of neem seed, yam } \\
\text { bean seed or citronella grass ( } 1: 50 \mathrm{~mL} \text { ratio), the } \\
2 \% \text { of wood vinegar showed larval mortality of } \\
92.5 \%, 50.0 \% \text { and } 45.0 \% \text {, respectively for a } 72 \mathrm{~h} \\
\text { test. And, by dropping method all of the } \\
\text { treatments showed } 100 \% \text { mortality of the } \\
\text { mosquito larvae after } 48 \mathrm{~h}\end{array}$ & 300 \\
\hline $\begin{array}{l}\text { Wood vinegar (obtained } \\
\text { from Energy Ashram, } \\
\text { Appropriate Technology } \\
\text { Association, Thailand) } \\
\text { and fermented bioextracts } \\
\text { from plants or animal } \\
\text { residues }\end{array}$ & $\begin{array}{l}\text { Enhance growth and yield } \\
\text { of tomato }\end{array}$ & $\begin{array}{l}\text { Alone or in combination, slightly increased plant } \\
\text { dry weight, fruit number, fruit fresh and weights. } \\
\text { Alone, wood vinegar and fermented bioextracts } \\
\text { showed similar effects on growth and yield of } \\
\text { tomato. Combined, extracts had an additive effect. }\end{array}$ & 301 \\
\hline
\end{tabular}


Table 16. Continuation.......

\begin{tabular}{|c|c|c|c|}
\hline Source and fraction used & Application & Observation & Ref. \\
\hline Coconut shell vinegar & $\begin{array}{l}\text { This review selected over } 10 \\
\text { chemical compounds that can be } \\
\text { used to develop new products and } \\
\text { discussed their applications in } \\
\text { different industries }\end{array}$ & $\begin{array}{l}\text { Food industry: anti-microbial, anti- } \\
\text { oxidant, flavor. } \\
\text { Pharmacy and cosmetics industry: } \\
\text { deodorizer, soap, sun screen cream, } \\
\text { sterilizing agent, anti-microbial agent } \\
\text { for treatment in skin diseases. } \\
\text { Chemical industry: latex coagulant } \\
\text { and rubber sheet additive, and wood } \\
\text { preservative. } \\
\text { Agricultural purposes: pesticide, } \\
\text { fertilizer and plant growth enhancer, } \\
\text { antifungal, feed-stuff, repellent and } \\
\text { insecticide }\end{array}$ & 302 \\
\hline $\begin{array}{l}\text { Wood vinegar prepared by } \\
\text { burning waste wood in a } \\
\text { charcoal kiln at } 120-430{ }^{\circ} \mathrm{C} \\
\text { and purified by standing and } \\
\text { filtering methods. }\end{array}$ & $\begin{array}{l}\text { Larvicide activity of wood vinegar } \\
\text { at different concentrations from } 10 \\
\text { to } 30 \% \text { against larvae of housefly } \\
\text { Musca domestica L. }\end{array}$ & $\begin{array}{l}\text { The feeding method was more } \\
\text { efficient than the topical application } \\
\text { method. Wood vinegar at } 10 \% \\
\text { concentration showed no effect on } \\
\text { mortality of } M \text {. domestica. Larval } \\
\text { mortality increased with increasing } \\
\text { concentration of wood vinegar and } \\
\text { the duration of exposure. } \\
\text { Larval and pupal duration were } \\
\text { extended by the treatments }\end{array}$ & 303 \\
\hline $\begin{array}{l}\text { Wood vinegar from chips of } \\
\text { sugi wood (Cryptomeria } \\
\text { japonica) hinoki wood } \\
\text { (Chamaecyparis obtusa), } \\
\text { hiba wood (Thujopsos } \\
\text { dolabrata) and bamboo } \\
\text { (Phyllostachys heterocycla) } \\
\text { obtained at different heating } \\
\text { rates }\left(2-8{ }^{\circ} \mathrm{C} / \mathrm{min}\right) \text { and } \\
\text { temperatures }\left(300-1000^{\circ} \mathrm{C}\right)\end{array}$ & $\begin{array}{l}\text { Fungicide activity against } \\
\text { Fomitopsis palustris and Trametes } \\
\text { versicolor on the agar medium and } \\
\text { termiticidal effectiveness using } \\
\text { Formosan subterranean termite, } \\
\text { Coptotermes formosanus }\end{array}$ & $\begin{array}{l}\text { Effective against termite and wood- } \\
\text { destroying fungi. The fungicidal } \\
\text { efficiency was significantly improved } \\
\text { with increasing heating rates, but } \\
\text { only slightly with temperature }\end{array}$ & 304 \\
\hline $\begin{array}{l}\text { Coconut shell oil supplied by } \\
\text { AVT Natural Products, } \\
\text { Karnataka, India. }\end{array}$ & $\begin{array}{l}\text { Termiticide compared to wood } \\
\text { preservatives currently in use }\end{array}$ & $\begin{array}{l}\text { Coconut shell oil has good } \\
\text { termiticidal activity. An } 18 \text { month } \\
\text { data showed that all the control } \\
\text { stakes were } 100 \% \text { destroyed, } \\
\text { compared to } 34.2 \% \text { damage in the } \\
\text { coconut shell oil brush coated stakes. }\end{array}$ & 305 \\
\hline
\end{tabular}


Table 16. Continuation.......

\begin{tabular}{|c|c|c|c|}
\hline Source and fraction used & Application & Observation & Ref. \\
\hline Wood Pyrolysis Liquids & 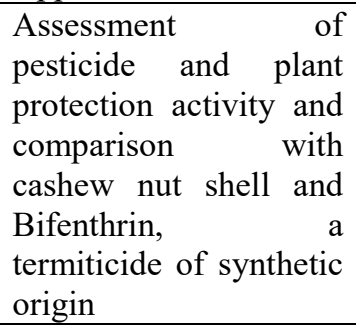 & $\begin{array}{l}\text { The replacement of synthetic pesticides with bio- } \\
\text { based ones is likely a slow process, as the chemical } \\
\text { composition and mode of action as a pesticide of } \\
\text { wood vinegar is still not completely understood. }\end{array}$ & 306 \\
\hline $\begin{array}{l}\text { Birch (Betula sp.) -derived } \\
\text { slow pyrolysis products, } \\
\text { birch tar oil, wood vinegar } \\
\text { and biochar }\end{array}$ & $\begin{array}{l}\text { Plant protection }- \\
\text { mollusk control and } \\
\text { herbicide }\end{array}$ & $\begin{array}{l}\text { Birch tar oil and wood vinegar were ineffective in } \\
\text { eradicating snails. Birch tar oil and the mixture of } \\
\text { birch tar oil and wood vinegar were good in repelling } \\
\text { snails and slugs. Soil organisms were more tolerant } \\
\text { of wood vinegar than aquatic organisms. } \\
\text { Wood vinegar offers negligible risk to soil and } \\
\text { aquatic organisms. }\end{array}$ & 307 \\
\hline
\end{tabular}

Production of synthesis gas: Studies about syngas production via gasification can be found in the literature ${ }^{354}$. Due to low ash content, pyrolysis oils potentially can be gasified in the 1000-1250 ${ }^{\circ} \mathrm{C}$ range ${ }^{354}$. Bio-oil to gas conversions as high as 83 wt. \% have been reported ${ }^{354}$. Composition of syngas obtained includes $16-36 \% \mathrm{CH}_{4}, 19-27 \%$, and $21-31 \% \mathrm{C}_{2} \mathrm{H}_{4}{ }^{168}$.

Asphalt paving substitution: The possibility of using bio-oil as a substitute for petroleum products in asphalt emulsions has been explored by several research groups ${ }^{369,370}$.

Resins and adhesives: Among the several possible applications of bio-oil phenolic compounds maybe the most common is the use as partial substitute of phenol in phenol-formaldehyde resins, such as, novalak and resole resins ${ }^{21,47,240}$. Phenol-formaldehyde resins can be utilized in molded products including billiard balls and laboratory countertops, and as adhesives for example in the manufacturing of wood panels such as plywood, medium density fiberboard (MDF), particle board and oriented strand board (OSB). The manufacture of wood panels such as plywood, MDF, particle board and OSB could employ renewable phenolic resins from bio-oils ${ }^{406,407}$. Resins are prepared by utilizing either the phenolic enriched fraction obtained after fractional condensation, further processing such as solvent extraction, or by utilizing the whole liquid product. None of the phenolic fractions produced allow 100\% substitution of the phenol content of the resins without impacting effectiveness, compared to commercial formulations based petroleum-derived phenol. High-quality resins can be produced from the replacement of 30-50\% of the phenol with pyrolytic lignin in novolak and resole formations despite the fact that lignin is 
less reactive than phenol. Further research is required to meet quality requirements and develop a low-cost renewable resin. Areas of concern include the variability of renewable resin properties, odor, and wood panel press times; the potential for increased emissions of volatile organic compounds; and the lack of reactive sites compared to phenol ${ }^{21,47,168}$.

There are some papers on the use the phenolic fraction from bio-oils for the development of thermo-responsive with adhesive properties. Extensive work has been done with lignins derived from chemical pulping technologies ${ }^{164,237,331-339}$; however, the phenolic fraction derived from pyrolysis is quite different than chemically-pulped lignins ${ }^{33,34,341}$. Sahaf et al. ${ }^{343}$ work showed that pyrolytic lignin can be used in its original uncombined form to produce a thermo-responsive polymer. A stabilized binder that responded to temperature similar to that of a thermoplastic was developed by utilizing a heat-treatment procedure to eliminate water and volatile mono-phenols. This phenolic fraction is likely not a polymer due to its low molecular weight $(>950 \mathrm{Mw})$; however, the thermo-responsive behavior is likely due to interparticle attractions and hydrogen bonding ${ }^{343}$. By thermally treating at differing temperatures, the thermoresponsive behavior can be tailored. A lap-shear test was applied to the glue-line when evaluating the bonding performance of the PRF to wood veneer.

Antioxidants: Bio-oil is a very good source of antioxidants due to the presence of lignin derived compounds ${ }^{360,361}$. Vanillin, identified in bio-oils ${ }^{29}$ has an antioxidant effect by protecting mitochondria against protein oxidation and lipid peroxidation induced by photosensitization. This effect is similar to that of the classic antioxidants such as the ascorbic acid and the singlet oxygen quencher, diazabicyclo[2.2.2]octane ${ }^{362}$. Other compounds with antioxidant properties present in bio-oils are the eugenol and hydroquinone ${ }^{29}$. Eugenol inhibits the copper-dependent oxidation of low density lipoproteins ${ }^{363}$ and prevents liver damage in rats by reducing the peroxidation indices and protein oxidation ${ }^{364}$. Hydroquinone is recognized as a potent skin lightening agent which also shows a potent 1,1-diphenyl-2-picrylhydrazyl radical scavenging activity $^{365}$. The antioxidant properties of the water-soluble and insoluble fractions derived from pyrolytic oils were investigated applying different assays ${ }^{360,361}$. Results showed that the waterinsoluble fraction presented a better capacity to scavenge radicals compared to the water-soluble fraction. It was attributed to the number of phenolic compounds which reached a maximum value $83.1 \%$ for ash tree wood $^{361}$. Important improvements in biodiesel oxidative stability has 
been reported when bio-oil phenolic fractions added to bio-diesel ${ }^{20,366,367}$. In summary, these results suggest that bio-oils could be considered as a source of natural antioxidants to be used for controlling imbalances caused by oxidative stress.

Carbon fiber: Polymer composites are materials that are obtained by reinforcing the polymer matrix, often a synthetic polymer, with suitable reinforcement material, generally fibers. Intense efforts are being made to use lignin as a low-cost eco-friendly reinforcement material to prepare high performance composites. Although most of these studies are mainly focused on lignin obtained from pulping or organosolv processes, some researchers have also investigated the use of pyrolytic lignin with this purpose $\mathrm{e}^{323}$. Carbon fibers from pyrolytic lignin are produced by thermal spinning and carbonization processes, and sometimes involving also other processes, such as, a previous polymerization or a stabilizing treatment by oxidation chemical preprocessing treatment of the pyrolytic lignin, such as, repolymerization ${ }^{323}$. According to these authors, the quality of the carbon fiber produced from pyrolytic lignin could be further improved by process optimization. Qin and Kadla ${ }^{371}$ found out that compared to other technical lignins, a lower spinning temperature was required for pyrolytic lignin and also that a thermal treatment before fiber spinning allowed to maintain the fiber integrity during thermostabilization and the following carbonization process. They also determined that the mechanical properties and the yield of the pyrolytic-lignin-based carbon fiber were comparable to those based on other technical lignins, indicating the suitability of pyrolytic lignin as a potential feedstock for lowcost carbon-fiber production. Kadla and Kubo ${ }^{325}$ investigated the influence of blending synthetic polymers to enhance the processability and flexibility in the fiber and reported that poly(ethylene oxide) (PEO)/and poly(ethylene terephthalate)(PET)/lignin polymer blends were miscible to produce robust fiber, whereas poly(vinyl alcohol) and polypropylene/lignin polymer blends showed poor miscibility and did not enhance the strength of the fiber.

Production of hydrogen: There are currently no commercial biomass processes for direct hydrogen production ${ }^{344,345}$, although some processes, such as, aqueous phase reforming and steam reforming, have been proposed. Aqueous phase reforming approach was developed by Dumesic and co-workers to produce $\mathrm{H}_{2}$, although the high-energy consumption, the low atom economy and the scarce purity of the $\mathrm{H}_{2}$ produced make this alternative economically unsuitable 411,412. $^{1}$. 
Steam reforming can be applied in order to transform aqueous fraction or light oxygenates, such as, acetic acid, ethanol, acetone, acetic acid, acetol or propanal, into $\mathrm{H}_{2}$, syngas or more valuable compounds. In this sense, acetic acid steam reforming has been largely studied in literature ${ }^{383,384}$. $\mathrm{Ni} / \mathrm{Al}_{2} \mathrm{O}_{3}$ catalyst has been used for $\mathrm{H}_{2}$ production via steam reforming and sequential cracking process $^{347}$. In addition, $\mathrm{Ni} /$ and $\mathrm{Ni}-\mathrm{Ce} / \mathrm{MgAlOx}$ catalysts have been studied employing light oxygenates (ethanol, acetone, acetic acid, acetol, propanal...) as model compounds of pyrolytic aqueous fractions ${ }^{385,386}$. In general, high-energy consumption and low atom economy of the process are the main drawbacks to overcome.

Aldol condensation and ketonization: The transformation of bio-oil water-soluble compounds by performing "one-pot" $\mathrm{C}-\mathrm{C}$ bonds formation reactions, such as aldol condensation and ketonization has recently been claimed as a beneficial alternative approach ${ }^{413-415}$. In this way, these short-chain and low value-added oxygenated compounds can be transformed, and further upgraded to generate a mixture of hydrocarbons and aromatics useful for blending with automotive liquid fuels.

Firstly, aldol condensation reactions have been largely studied by different authors employing basic mixed oxides (i.e. $\mathrm{Mg}$ - $\mathrm{Al}$ derived hydrotalcites, $\mathrm{MgO}, \mathrm{ZnO}$ ) as active materials for acetone-furfural aqueous phase condensation reactions under moderated conditions ${ }^{416,417}$. Moreover, $\mathrm{MgO}$ and $\mathrm{Mg} / \mathrm{Zr}$ oxides have also been used to study acetone gas-phase selfcondensation under higher temperature conditions $\left(200-300^{\circ} \mathrm{C}\right){ }^{418,419}$. The use of amphoteric or acid mixed oxides with well-distributed active sites can as well effectively perform these reactions. In this sense, catalysts based on CeZrO mixed oxides have been widely considered ${ }^{415}$ for the gas-phase conversion of small aldehydes at high temperatures $\left(>300{ }^{\circ} \mathrm{C}\right)$, whereas $\mathrm{TiO}_{2}-$ based materials have been used for the acetone-furfural condensation reaction at moderated conditions $^{420}$.

In a similar way, the same oxides can be used as catalysts for ketonic decarboxylation or ketonization reactions of carboxylic acids, where two molecules of short chain acids are transformed in one larger chain ketone via $\mathrm{C}-\mathrm{C}$ bond formation, also producing $\mathrm{CO}_{2}$ and $\mathrm{H}_{2} \mathrm{O}$ during reaction. This process contributes reducing carboxylic acids content, thus avoiding $\mathrm{pH}$ and corrosivity problems of the mixture, while additionally allows hydrocarbon chain growth by means of consecutive $\mathrm{C}-\mathrm{C}$ bonds formations. 
In the last years, both reaction mechanisms have been deeply studied by using acetic acid or propanal as probe molecules with $\mathrm{TiO}_{2}$ and $\mathrm{ZrO}_{2}$ as catalysts ${ }^{421,422}$. These studies conclude that the activity of these catalysts is based on their bifunctional character (acid/base sites combination), necessary to assist intermediates formation on the surface of the catalyst. Different strategies even with the incorporation of noble metals on the solid catalyst have been attempted ${ }^{414}$.

Most of these studies were performed using single compounds under conditions distant from realistic operation conditions, and not many examples of complex mixtures can be found in literature. Water effect on acetic acid ketonization ${ }^{414}$ and furfural, acetol or cresol effects on acetic acid ketonization ${ }^{423}$ were studied, meanwhile the effect of acid and water on propanal condensation was carefully considered ${ }^{415}$. In addition, these studies also show CeMOx (Ce, Mn, $\mathrm{Al}$ ) catalysts to have poor structural stability, while $\mathrm{TiO}_{2}, \mathrm{ZrO}_{2}$ lose catalytic activity at high temperatures, being this effect enhanced by the presence of water. More recently, hydrothermal niobium oxides and $\mathrm{WNbO}$ materials have been claimed as active and stable catalysts when dealing with complex mixtures simulating aqueous effluents obtained by phase separation of pyrolytic bio-oils ${ }^{424,425}$. Based on these considerations, the study of catalytic activity and stability of materials under more realistic operation conditions and employing aqueous complex mixtures is essential to effectively advance in this particular approach.

Food additives: Smoking to preserve food has become less and less important over the course of the last 50 years and today fish and meat are typically smoked only for flavoring reasons. Glucoaldehyde, glyceraldehydes, pyruvaldehyde, dihydroxyacetone, acetone, and diacetyl are effective browning agents ${ }^{168}$. An application that has been commercial for over 10 years uses the water-soluble part of fast pyrolysis bio-oil as browning agent. Both phenolic compounds that provide the smoky flavors and the low-molecular-weight aldehydes that are effective meat browning agents (especially glycolaldehyde) are included in the aqueous extract of bio-oil. Methods for the isolation of glycolaldehyde based on crystallization have been patented by Red Arrow Products and RTI. This compound is susceptible to decomposition at temperatures higher than $100^{\circ} \mathrm{C}$. If glucose is used instead of wood as the feedstock for fast pyrolysis, the production of glycolaldehyde becomes more attractive ${ }^{47}$. A new method for the separation of glycoaldehyde from pyrolysis oil via physical extraction has been reported by researchers from the Eindhoven 
University of Technology ${ }^{17}$. Reactive extraction with the use of tertiary amines for separating acid compounds is incorporated in the conceptual design.

Production of polyethers: We are not aware of any research activity that uses the aqueous fraction of bio-oil to make plastics. However, some studies describe the synthesis of polymers from the anhydrosugars (levoglucosan, cellobiosan, and oligomers) in the water soluble fraction $^{326-328,330 .}$.

Bio-Products from fermentable sugars: Via microbial fermentation, fermentable sugars can produce different chemicals and commodity, such as ethanol, organic acids (e.g., citric acid, fumaric acid, lactic acid, propionic acid, succinic acid, itaconic acid, acetic acid and butyric acid), amino acids, antibiotics, fatty acids, and others (e.g., glycerol, acetone, n-butanol, butanediol, isopropanol, and acetaldehyde) ${ }^{229,399}$. Moreover, it is known that fermentable sugars can be used in the production of second-generation bio-fuels through several different technologies. Huber et al. ${ }^{400}$ list several pathways to produce hydrocarbons, $\mathrm{H}_{2}, \mathrm{CH}_{4}$ and above all ethanol from sugars. The sugars can also, through chemical conversion, originate products like furfural, furans, glycols, methyl ethyl ketone, adipic acid, ethylene and propylene ${ }^{401,402}$. This list continues if one assumes that these products can undergo further processing and originate even more products. However, the production of ethanol via fermentation of sugars remains the most commonly used technology ${ }^{229}$.

Ethanol is a well-known bio-fuel and an interesting platform chemical since fermentation is already used industrially to produce it from biomass in bulk quantities. The world ethanol production was estimated at 40 billion liters in $2003^{115}$. The three major uses for ethanol are: fuel and fuel additive (69\%), as a solvent and a building block for chemical synthesis (21\%), and as an ingredient of alcoholic drinks and a disinfectant and a preserving agent in the food industry $(10 \%)^{115}$. The production of ethanol from the fermentation of pyrolytic sugars is described in several papers ${ }^{229,230,355-358}$.

Bio-carbon electrodes: The production of graphite-like materials using bio-pitch, heaviest fractions obtained by distillation of pyrolysis oils, has been studied by Coutinho et al. ${ }^{23}$. Biopitch is compressed with ground solid charcoal and a $120 \mathrm{~mm}$ length and $25 \mathrm{~mm}$ diameter green, pre-molded electrode is obtained. It is cured using a treatment involving an increasing 
temperature. Following the curing step, the electrode then undergoes calcinations at $1000^{\circ} \mathrm{C}$, followed by graphitization at $2700{ }^{\circ} \mathrm{C}$. The bio-oil derived electrode has comparable properties to the ordinary electrodes ${ }^{23}$. Elliott et al. ${ }^{373}$ recently studied the hydroprocessing of bio-oil and the separation of heavy fractions for coke production proposing its use for the manufacture of lowsulfur electrode carbon.

Olefins: Extensive work has been done on ketonization of carboxylic acids (chiefly acetic acid) over both alkali earth metal oxides and transition metal oxides $\left(\mathrm{Mn}_{2} \mathrm{O}_{3}-\mathrm{CeO}_{2}, \mathrm{TiO}_{2}, \mathrm{ZrO}_{2}\right.$, and $\left.\mathrm{CeO}_{2}\right)^{312-314}$. In addition, ketone conversion to olefins has been reported over Brønsted acid sites of zeolites (HZSM5, H-BEA) ${ }^{315-319}$. Not until recently was direct acetic acid conversion to isobutene with a $50 \%$ yield achieved. This process used acetic acid ketonization to acetone, followed by acetone aldol condensation to mesityl oxide and mesityl oxide cracking on $\mathrm{Zn} / \mathrm{Zr}$ catalyst with Brønsted acid active sites prepared by co-precipitation. The group of Co-PI Wang recently found that $\mathrm{Zn}_{\mathrm{x}} \mathrm{Zr}_{\mathrm{y}} \mathrm{O}_{\mathrm{z}}$ catalysts with balanced Lewis acid-base pairs convert bio-acetone (acetone $/ \mathrm{H}_{2} \mathrm{O}$ solution) to isobutene ${ }^{320,322,372}$.

Surfactants: Oils to produce surfactants are recovered at various stages of tar distillation and during raw acetic acid refining. They range from transparent to dark brown and have a characteristic smell. More than 10 commercial grades are known and made according to specifications, classified by specific weight, viscosity, calorific value and boiling point. They are widely used in the flotation process for the separation and beneficiation of ores ${ }^{55}$. The price of flotation agents is $\$ 400-2,300 \mathrm{t}^{-1}$.

Products derived from Acetic Acid: Acetic acid can be transformed in other valuable products by several methods including ketonization, esterification and steam reforming, among others. Firstly, acetic acid ketonization has been previously discussed as one of the principal approaches considered in literature. Ketonic decarboxylation or ketonization consists of two moles of acid transformed in one mol of acetone and one mol of $\mathrm{CO}_{2}$ and $\mathrm{H}_{2} \mathrm{O}$ as the only byproducts. In such a way, acetone can be produced from acetic acid via new $\mathrm{C}-\mathrm{C}$ bond formation, this process being of great importance. $\mathrm{CeO}_{2}, \mathrm{ZrO}_{2}, \mathrm{CeZrO}$ and rare earth metals have been largely studied for $\mathrm{C} 2-$ C5 organic acid gas-phase ketonization reactions at high temperatures $\left(300-500{ }^{\circ} \mathrm{C}\right)^{374-377}$. Organic acid and aqueous mixtures containing acetic acid have been considered as model compounds/mixtures when studying this approach. Atom economy of the process and operation 
conditions traditionally used are the main drawbacks when dealing with this alternative. On the other hand, acetic acid can react with different alcohols via esterification to produce the corresponding ester together with $\mathrm{H}_{2} \mathrm{O}$ as byproduct. This reaction pathway has been considered by other authors in order to "catalytic stabilize" aqueous effluents obtained by phase separation of pyrolytic bio-oils or pyrolytic bio-oils themselves. The use of acid catalysts (ionic exchange polymeric resins, such as Amberlyst) together with different alcohols (methanol, ethanol, butanol) under moderated conditions can reduce carboxylic acid contents (TAN/pH reduction), also reducing corrosivity and reactivity concerns when using aqueous effluents derived from pyrolytic bio-oils. Traditional distillation, azeotropic water removal or reactive distillation need to be used in order to increase this process efficiency ${ }^{121,238,378,379}$.

Ethanol production from the hydrogenation of acetic acid has been extensively studied ${ }^{309-}$ 311,380,381. The most common catalysts used are noble metals ( $\mathrm{Ru}, \mathrm{Pd}, \mathrm{Pt})$ on $\mathrm{C}$ and $\mathrm{TiO}_{2}$, and the reaction is typically conducted at temperatures between 150 and $300{ }^{\circ} \mathrm{C}^{139,310,380}$. Ito et al. ${ }^{309}$ studied the hydrogenation of acetic acid in the presence of $\mathrm{Ru}-\mathrm{Sn} / \mathrm{TiO}_{2}$ for ethanol production. $\mathrm{Ru}$ and $\mathrm{Sn}$ form alloys and the researchers found that the addition of Sn (2-4 wt. \%) improves ethanol selectivity by the suppression of gas production ${ }^{309}$. These authors proposed a mechanism for acetic acid hydrogenation at the $\mathrm{Ru}-\mathrm{TiO}_{2}$ interface in which carbonyl activation through coordination with $\mathrm{Ti}$ significantly enhanced hydrogenation ${ }^{309}$. Rachmady and Vannice ${ }^{382}$ investigated $\mathrm{Pt}$ loaded on $\mathrm{SiO}_{2}, \mathrm{Al}_{2} \mathrm{O}_{3}, \mathrm{Fe}_{2} \mathrm{O}_{3}$ and $\mathrm{TiO}_{2}$ for acetic acid hydrogenation to ethanol. The reaction was studied in vapor phase between 150 and $300{ }^{\circ} \mathrm{C} . \mathrm{TiO}_{2}$ showed the best catalytic performance.

Products derived from Acetol: Due to its high reactivity and usability in organic synthesis, acetol becomes a key intermediate for chemical industry. Acetol has hydroxyl and carbonyl functional groups and, therefore, can promote a lot of reactions, such as dehydration, hydrogenation, oxidation and polymerization ${ }^{388}$. Propylene glycol, acetone, acrolein, furan derivatives and propionaldehyde are examples of products derived from acetol.

Besides, it can be directly used in food, textile and cosmetic industries. In food industry, it can be used to provide aroma to foods and to induce flavor in heated milk. In textile industry, acetol can substitute sodium dithionite, usually used to allow fixation of the dye in the textile by decreasing the dye to a water-soluble compound. And, in cosmetic industry, acetol serves as main 
constituent of skin tanning agent ${ }^{392}$ in addition to provide access to important natural carbohydrates and unnatural polyhydroxylated molecules in medicine ${ }^{220}$. Acetol can promote various reactions (e.g. dehydration, hydrogenation, oxidation) and produce numerous products including propylene glycol, acrolein, acetone, and furan derivatives ${ }^{220}$.

Products derived from Hydroxyacetaldehyde: Hydroxyacetaldehyde, also named glycoaldehyde, is a precursor of ethylene glycol through either hydrogenation or fermentation process ${ }^{223,393}$. Ethylene glycol can be used as coolant and antifreeze, as monomer in the production of polyester, as solvent, and as intermediate for chemicals production, among other applications ${ }^{393}$. Besides, hydroxyacetaldehyde is used as food browning agent ${ }^{395}$ and for producing flavors when contacting hydroxyacetaldehyde with ammonia or amines ${ }^{227}$. Finally, it has been reported that hydroxyacetaldehyde may also be used to prepare an artificial tanning product to give a brown color to $\operatorname{skin}^{227}$. Glycoaldehyde can be used as an effective meat-browning agent ${ }^{395}$ or as a fermentation feedstock to produce ethylene glycol ${ }^{223}$. Liquid smoke aroma for the food industry serves for preservation, flavoring and coloring in the treatment of meat, sausages, and cheese to replace the time-consuming and ineffective traditional smoking procedure. In addition, smoke flavoring are increasingly used in soups, sauces, and snacks. Within the EU such liquid flavoring needs to be authorized by the European Food Safety Authority (EFSA) ${ }^{1}$

Ethylene/propylene glycol production: Very few studies mention the heterogeneous catalytic production of ethylene/propylene glycol from hydroxyacetaldehyde and acetol. Most of the reports in the literature consider these compounds as intermediates of cellulose or glycerol hydrogenation ${ }^{139}$. In contrast ethanol production from the hydrogenation of acetic acid has been extensively studied ${ }^{152,309-311}$. Although the electrochemical reduction of various organic molecules has been demonstrated over the past decades, there is very limited information on acetol and hydroxyacetaldehyde electrochemical reduction ${ }^{152,309-311}$.

Products derived from levoglucosan: By using demineralized cellulose, high yields of levoglucosan (1,6-anhydro- $a$-D-glucopyranose) (up to 46 wt. \%) and levoglucosenone $(6,8$ dioxabicyclo[3.2.1.] oct-2-en-4-one) (up to 24 wt. \%) can be generated ${ }^{47}$. Considerably lower yields $(<10 \%)$ of levoglucosan are produced from the pyrolysis of lignocellulosic materials. The efficient isolation of levoglucosan from the pyrolytic liquids is one of the main difficulties 
involved in its production. Due to the high production price of levoglucosan from lignocellulosic materials, it is unlikely to see extensive use in the near future despite its potential for the manufacturing of pharmaceuticals, surfactants, biodegradable polymers, and others ${ }^{47}$. It is known that levoglucosan can be hydrolyzed to glucose, being a potential route to bio-ethanol production $^{396,397}$. In similar way, it is also a potential route for fatty-acids production ${ }^{229}$. Levoglucosan could serve as chiral synthon to control stereo-selective reactions during synthesis $^{1}$. However, the application of levoglucosan is much more extensive. It has been reported as an important element on the production of antibiotics, antiparasitic agents, and other biologically active compounds ${ }^{47,188,398}$. Levoglucosan could be used as a raw material to produce many materials, such as plasticizers, propellants, explosives, surfactants, resins, plastics, and others $^{235}$.

Products derived from pyrolytic humins: Although it was not possible to find products derived from pyrolytic humins there is a growing body of literature on products from humins by products of hydroxyMethyl Furfural/Furfural/FuranDiCarboxylic Acid bio-refinery ${ }^{426}$. These humins are obtained from acid treatment of polysacchairdes and showed very interesting properties as semiductile thermoset matrix to impregnate cellulosic fibers with enhanced modulus and tensile strength compared with pure polyfurfurylalcohol resins ${ }^{426}$. Initial ecotoxicity and biodegrability tests of humins did not show any immediate concern ${ }^{427}$.

\section{Conclusions}

The growth of the pyrolysis industry is severely hindered by the lack of commercial bio-oil refineries. Although we do not have a standardized strategy to characterize bio-oil and to separate it in groups or families, the overall chemical makeup of these oils is becoming better known. The four major bio-oil compounds with potential to be commercialized as purified molecules are acetol, hydroxyacetaldehyde, acetic acid, levoglucosan. The rest of the bio-oil needs to be commercialized as fractions. Bio-oil upgrading into a low-quality heavy oil substitute and bio-oil refining to transportation fuels are the two main strategies so far explored for the commercialization of these oils. These concepts remain at demonstration stage due to unsolved operational challenges and high production costs. The increase in the number of papers in bio-oil separation together with the development of equilibrium models to describe the behavior of pyrolysis oils in separation units is encouraging. There are many opportunities to separate bio-oil 
fractions and convert them into value added co-products in new integrated biorefinery schemes. Despite these progresses, very few fully integrated bio-refinery concepts have been reported in the literature. The synthesis, techno-economic and environmental evaluation of novel integrated bio-oil refinery concepts for fuels and chemicals production is likely to become a subject of intense research activity in the coming years.

Acknowledgements: The authors are very thankful to the Washington State Department of Ecology and the Federal Aviation Administration for their partial financial support to collect part of the information contained in this review. Dr. Garcia-Perez is also very thankful to the USDA/NIFA through Hatch Project \# WNP00701 for funding his research program.

\section{References:}

1. Meier D: Pyrolysis Oil Biorefinery. In: Adv. Biochem. Eng. Biotechnol. Springer international, Berlin, Heidelberg, 2017, 1-37.

2. Stankovikj F., McDonald A. G., Helms G. L., Garcia-Perez M., Quantification of Bio-Oil Functional Groups and Evidences of the Presence of Pyrolytic Humins. Energy \& Fuels, 2016; 30:6505-6524.

3. Garcia-Perez M, Chaala A, Roy C: Co-pyrolysis of sugarcane with petroleum residue. Part II. Product yields and properties. Fuel, 2002, 81, 7, 893-907

4. Ensyn: The world leading biocrude producer. Investing in the bio-economy. Jully 11, 2017 (at: https://www.energy.gov/sites/prod/files/2017/10/f38

5. Mettler M, Vlachos DG, Dauenhauer PJ: Top ten fundamental challenges of biomass pyrolysis for biofuels. Energy Environ. Sci., 2012, 5, 7797-7809

6. Bridgwater AV: Review of fast pyrolysis of biomass and product upgrading. Biomass and Bioenergy, 2012, 38, 68-94

7. Kan T, Strezov V, Evans TJ: Lignocellulosic biomass pyrolysis: A review of product properties and effects of pyrolysis parameters. Renewable and Sustainable Energy Reviews, 2016, 57, 1126-1140

8. Venderbosch, R. H., Prins, W., Fast Pyrolysis technology development. Biofuels Bioprod. Biorefin., 2010; 4:178-208. 
9. Butler E, Devlin G, Meier D, McDonnell K: A review of recent laboratory research and commercial developments in fast pyrolysis and upgrading. Renewable and Sustainable Energy Reviews, 15, 2011, 4171-4186

10. Kersten S, Garcia-Perez M: Recent developments in fast pyrolysis of lingo-cellulosic materials. Current opinion in biotechnology, 2013, 24 (3), 414-420

11. Garcia-Nunez JA, Pelaez-Samaniego MR, Garcia-Perez ME, Fonts I, Abrego J, Westerhof RJM, Garcia-Perez M: Historical Developments of Pyrolysis Reactors: A Review. Energy Fuels, 2017, 31 (6) , 5751-5775

12. Oasmaa A, Fonts I, Pelaez-Samaniego MR, Garcia-Perez ME, Garcia-Perez M: Pyrolysis Oil Multiphase Behavior and Phase Stability: A Review. Energy Fuels, 2016, 30 (8), $6179-6200$

13. Lehto J, Oasmaa A, Solantausta Y, Kyto M, Chiriamonti D: Review of fuel oil quality and combustion of fast pyrolysis bio-oils from lignocellulosic biomass. Applied Energy, $2014,116,178-190$

14. Carpenter D, Westover TL, Czernik S, Jablonski W: Biomass feedstocks for renewable fuel production: A review of the impacts of fedstock and pretreatment on the yield and product distribution of fast pyrolysis bio-oil and vapors; Greem Chemistry, 2014,

15. Zacher A, Olarte MV, Santosa DM, Elliott DC, Jones SB: A review and prespective of recent bio-oil hydrotreating research. Greeen Chemistry, 2014, 2,

16. Rasrendra, C. B., Girisuta, B., van de Bovenkamp, H. H., Winkelman, J. G., M., Leijenhorst, E. J., Venderbosch, R. H., Windt, M., Meier, D., Heeres, H. J. Recovery of acetic acid from an aqueous pyrolysis oil phase by reactive extraction using tri- $n$ octylamine. Chemical Engineering Journal, 2011; 176-177: 244-252.

17. Vitasari et al. 2010. Conceptual process design of glycolaldehyde isolation from pyrolysis oil via physical extraction route. Eindhoven University of Technology. Netherlands. www.biocoup.com/fileadmin/user/december/00_64_TUE_March10.pdf

18. Vitasari, C. R., Meindersma, G. W., de Haan, A. B. Glycolaldehyde co-extraction during the reactive extraction of acetic acid with tri-n-octylamine/2-ethyl-1-hexanol from a wood-based pyrolysis oil-derived aqueous phase. Separation and Purification Technology, 2012; 95: 39-43. 
19. Vitasari, C. R., Meindersma, G. W., de Haan, A. B. Conceptual process design of an integrated bio-based acetic acid, glycolaldehyde, and acetol production in a pyrolysis oilbased biorefinery. Chemical Engineering Research and Design, 2015; 95: 133-143.

20. Garcia-Perez M, Shen J, Wang X-S, Li C-Z: Production and fuel properties of fast pyrolysis oil/bio-diesel blends. Fuel. 2010, 91, 3, 296-305

21. Effendi, A., Gerhauser, H., Bridgwater, A. V. Production of renewable phenolic resins by thermochemical conversion of biomass: A review. Renewable and Sustainable Energy Reviews, 2008; 12: 2092-2116.

22. Resasco DE, Sooknoi T, Zhu X, Huang T, Lobban L, Mallinson RG: Catalytic conversion of small oxygenates from bio-oil to alkylaromatics on zeolite. School of Chemical, Biological and Materials Engineering and Center for Biomass Refining, University of Oklahoma (2010)

23. Coutinho AR, Rocha JD, Luengo CA: Preparing and characterizing biocarbon electrodes. Fuel Processing Technology. Vol. 67, 2, 2000, 93-102

24. Garcia-Perez, M.; Chaala, A.; Pakdel, H.; Kretschmer, D.; Roy, C., Characterization of bio-oils in chemical families. Biomass Bioenergy, 2007; 31 (4): 222-242.

25. Lehto, J., Oasmaa, A., Solantausta, Y., Kytoo, M, Chiaramonti, D. Fuel oil quality and combustion of fast pyrolysis bio-oils. VTT Technol. 2013; p. 79.

26. Oasmaa, A., Sundqvist, T., Kuoppala, E., Garcia-Perez, M., Solantausta, Y., Lindfors, C., Paasikallio, V. Controlling the phase stability of biomass fast pyrolysis bio-oils, Energy \& Fuels, 2015; 29: 4373-4381.

27. Oasmaa, A., Peacocke, C. Properties and fuel use of biomass derived fast pyrolysis liquids. A guide. Technical Research Centre of Finland: Espoo, Finland, 2010.

28. Oasmaa, A., Leppämäki, E., Koponen, P., Levander, J., Tapola, E. Physical characterisation of biomass-based pyrolysis liquids. Application of standard fuel oil analyses. Technical Research Centre of Finland: Espoo, Finland, 1997.

29. Stankovikj F, McDonald AG, Helms GL, Olarte MV: Characterization of the WaterSoluble Fraction of Woody Biomass Pyrolysis Oils. Energy Fuels, 2017a, 31, 1650-1664

30. Stankovikj F, Garcia-Perez M: TG-FTIR Method for Characterization of Bio-oils in chemical Families. Energy Fuels, 2017b, 31, 2, 1689-1701 
31. Ferrell JR, Olarte MV, Christensen ED, Padmaperuma AB, Connatser RM, Stankovikj F, Meier D, Paasikallio: Standarization of chemical analytical techniques for pyrolysis biooil: history, challenges, and current status of methods. Biofuels, Bioproducts \& Biorefining, 2016, 10, 5, 496-507

32. Rover, M. R., Analysis of sugars and phenolic compounds in bio-oil. PhD Dissertation, Iowa State University, Ames, Iowa, 2013.

33. Scholze, B., Meier, D., Characterization of the water-insoluble fraction from pyrolysis oil (pyrolytic lignin). Part I. PY-GC/MS, FTIR, and functional groups. Journal of Analytical and Applied Pyrolysis, 2001; 60:41-54.

34. Scholze B, Hanser C, Meier D: Characterization of the water-insoluble fraction from fast pyrolysis liquids (pyrolytic lignin): Part II. GPC, carbonyl groups and ${ }^{13} \mathrm{C}-\mathrm{NMR}$ Journal of Analytical and Applied Pyrolysis, 2001, 58-59, 387-400

35. Bayerbach R, Meier D: Characterization of the water-insoluble fraction from fast pyrolysis liquids (pyrolytic lignin). Part IV: Structure elucidation of oligomeric molecules. Journal of Analytical and Applied Pyrolysis, 2009, 85, 1-2, 98-107

36. Lee, E. H., Park, R., Kim, H., Park, S. H., Jung, S., Jeon, J., Kim, S. C., Park, Y.. Hydrodeoxygenation of guaiacol over Pt loaded zeolitic materials. Journal of Ind. and Eng. Chem., 2016; 37:18-21.

37. Yoosuk, B., Boonpo, J., Udomsap, P., Sukkasi, S., Investigation of operating parameters of water extraction processes for improving bio-oil quality. Korean J. Chem. Eng., 2014; 31: 2229-2236.

38. Soya, R., Choi, Y. S., Choi, S. K., Kim, S. J., Han, S. Y., Synergetic effect of biomass mixture on pyrolysis kinetics and biocrude-oil characteristics. Korean J. Chem. Eng., 2016; 33: 603-609.

39. Resasco, D. E., Crossley, S. P., Implementation of concepts derived from model compound studies in the separation and conversion of bio-oil to fuel. Catal. Today, 2015; 257: $185-199$.

40. Lee, H. W., Park, S. H., Jeon, J., Ryoo, R., Kim, W., Suh, D. J., Park, Y., Upgrading of bio-oil derived from biomass constituents over hierarchical unilamellar mesoporous MFI nanosheets. Catal. Today, 2014; 232: 119-126. 
41. Ko, C. H., Park, S. H., Jeon, J. K., Suh, D. J., Jeong, K. E., Park, Y. K., Upgrading of biofuel by the catalytic deoxygenation of biomass. Korean J. Chem. Eng., 2012; 29: $1657-1665$.

42. Zhang, Q., Chang, J., Wang, T., Xu, Y., Review of biomass pyrolysis oil properties and upgrading research. Energy Convers. Manage., 2007; 48: 87-92.

43. Garcia-Perez M, Wang X-S, Shen J, Rhodes MJ, Tian F, Lee W-J, Wu H, :Li C-Z: Fast Pyrolysis of Oil Mallee Woody Biomass: Effect of Temperature on the Yield and Quality of Pyrolysis Products. Ind. Eng. Chem. Res. 2008, 47, 1846-1854

44. Pecha M.B., Montoya JI, Chejne F., Garcia-Perez M. Effect of Vacuum on the Fast Pyrolysis of Cellulose: Nature of Secondary Reactions in a Liquid Intermediate. Ind. Eng. Chem. Res., 2017, 56 (15), 4288-4301

45. Meier, D. In Fast Pyrolysis of Biomass: A Handbook; CPL Press: Newbury, UK, 1999; pp 92-101.

46. Hallet WLH, Clark NA: A model for the evaporation of biomass pyrolysis oil droplets. Fuel, 2006, 85, 532-544

47. Czernik S., Bridgwater A. V., Overview of applications of biomass fast pyrolysis oil. Energy and Fuels, 2004; 18:590-598.

48. Bridgwater A. V., Production of high grade fuels and chemicals from catalytic pyrolysis of biomass. Catal. Today, 1996; 29: 285-295.

49. Goyal H. B., Seal D., Saxena R. C., Bio-fuels from thermochemical conversion of renewable resources: A review. Renew. Sustain. Energy Rev., 2008; 12: 504-517.

50. Zhou X., Mayes H., Broadbelt L.J., Nolte M.W. Fast Pyrolysis of glucose-based carbohydrates with added $\mathrm{NaCl}$ part 1: Experimental and development of mechanistic model. AIChE Journal 2016, 62, 3, 766-777

51. Montoya J, Pecha B, Chejne F, Garcia-Perez M: Micro-explosion of liquid intermediates during the fast pyrolysis of sucrose and organosolv lignin. Journal of Analytical and Applied Pyrolysis 122, 2016, 106-121

52. Bayerbach R, Nguyen VD, Schurr U, Meier D: Characterization of the water-insoluble fraction from fast pyrolysis liquids (pyrolytic lignin): Part III. Molar mass characteristics 
by SEC, MALDI-TOF-MS, LDI-TOF-MS and Py-FIMS. Journal of Analytical and Applied Pyrolysis. 2006, 77, 2, 95-101

53. Westerhof RJM, Oudenhoven SRG, Marathe PS, Engelen M, Garcia-Perez M, Wang Z, Kerten SRA: The interplay between chemistry and heat/mass transfer during the fast pyrolysis of cellulose. React. Chem. Eng., 2016, 1, 555-566

54. Garcia-Perez M, Chaala A, Pakdel H, Kretchmer D, Roy C: Vacuum pyrolysis of softwood and hrdwood biomass: Comparison between products and bio-oil properties. Journal of analytical and appl pyrolysis, 2007, 78, , 104-116

55. Emrich W: Handbook of Charcoal Making. The traditional and Industrial Methods. Edited by Walter Emrich. D. Reidel Publishing Company. 1985

56. Garcia-Perez M., Garcia-Nunez, J.A., Lewis, T., Kruger, C. E., Kantor, S. Methods for Producing Biochar and Advanced Bio-fuels in Washington State. Part 3: Literature Review of Technologies for Product Collection and Refining. Third Project Report. Department of Biological Systems Engineering and the Center for Sustaining Agriculture and Natural Resources, Washington State University, Pullman, WA, 129 pp, 2011.

57. Adjaye JD, Sharma RK, Bakhshi NN: Characterization and stability analysis of woodderived bio-oil. Fuel Processing Technology, 1992, 31, 3, 241-256Magg

58. Maggi R, Delmon B: A review of catalytic hydrotreating processes for the upgrading of liquids produced by flash pyrolysis. Studies in Surface Science and Catalysis, 1997, 106, 99-113

59. Elliot, D. C. Historical developments in hydroprocessing bio-oils. Energy Fuels, 2007; 21 (3): 1792-1815.

60. Wang, H., Male, J., Wang, Y., Recent advances in hydrotreating of pyrolysis bio-oil and its oxygen-containing model compounds. ACS Catal., 2013a; 3:1047-1070.

61. Elliot DC: Biofuels from fast pyrolysis and catalytic hydrodeoxygenation. Current Opinion in Chemical Engineering, 2015, Vol. 9, 59-65

62. Nava, R., Pawelec, B., Castaño, P., Álvarez-Galván, M. C., Loricera, C. V., Fierro, J. L. G. Upgrading of bio-liquids on different mesoporous silica-supported CoMo catalysts. Applied Catalysis B: Environmental, 2009; 92: 154-167. 
63. Baker, E. G.; Elliott, D. C. Method of Upgrading Oils Containing Hydroxyaromatic Hydrocarbon Compounds to Highly Aromatic Gasoline. U.S. Patent Number 5,180,868, January 19, 1993.

64. Elliott, D. C.; Baker, E. G. Process For Upgrading Biomass Pyrolyzates. U.S. Patent Number 4,795,841, January 3, 1989

65. Zacher, A. H., Olarte, M. V., Santosa, D. M., Elliott, D. C., Jones, S. B., A review and perspective of recente bio-oil hydrotreating research. Green Chem., 2014; 16: 491-515.

66. De Miguel-Mercader F, Koehort PJJ, Heeres HJ, Kersten SRA, Hogendoorn JA: Competition between hydrotreating and polymerization reactions during pyrolysis oil hydrodeoxygenation, AiChE Journal, 2011, 57, 11, 3160-3170

67. Wright MM, Daugaard DE, Satrio JA, Brown RC: Techno-economic analysis of biomass fast pyrolysis to transportation. Fuel, 89, 1, November 2010, S2-S10

68. Elliott, D. C., Hart, T. R., Neuenschwander, G. G., Rotness, L. J. and Zacher A. H. Catalytic hydroprocessing of biomass fast pyrolysis bio-oil to produce hydrocarbon products. Environ. Prog. Sustain. Energy, 2009; 28(3): 441-449.

69. Elliott, D. C., Hu, J., Hart, T. R., Neuenschwander, G. G. Palladium catalyzed hydrogenation of bio-oils and organic compounds, U.S. Patent 7,425,657, Sep.16, 2008.

70. Wildschut, J., Mahfud, F. H., Venderbosch, R. H., Heeres, H. J. Hydrotreatment of fast pyrolysis oil using heterogeneous noble-metal catalysts. Ind. Eng. Chem. Res., 2009; 48: 10324-10334.

71. Lee H., Kim H., Yu M. J., Ko C. H., Jeon J. -K., Jae J., Park S. H., Jung, S. -C, Park Y.$\mathrm{K}$., Catalytic hydrodeoxygenation of bio-oil model compounds over Pt/HY Catalyst. Scientific Reports 6, 2016a; art. no. 28765.

72. Mercader, F. D., Groeneveld, M. J., Kersten, S. R. A., Geantet, C., Toussaint, G., Way, N. W. J., Schaverien, C. J., Hogendoorn, K. J. A. Hydrodeoxygenation of pyrolysis oil fractions: process understanding and quality assessment through co-processing in refinery units. Energy Environ. Sci., 2011; 4 (3): 985-997.

73. Wildschut, J., Iqbal, M., Mahfud, F. H., Cabrera, I. M., Venderbosch, R. H., Heeres, H. J. Insights in the hydrotreatment of fast pyrolysis oil using a ruthenium on carbon catalyst. Energy Environ. Sci., 2010; 3: 962-970. 
74. Koike, N., Hosokai, S., Takagaki, A., Nishimura, S., Kikuchi, R., Ebitani, K., Suzuki, Y., Oyama, S. T. Upgrading of pyrolysis bio-oil using nickel phosphide catalysts. Journal of Catalysis, 2016; 333: 115-126.

75. Majhi A, Sharma YK, Bal R, Behera B, Kumar J: Upgrading of bio-oils over $\mathrm{PdO} / \mathrm{Al}_{2} \mathrm{O}_{3}$ catylyst and fractionation. Fuel, 2013, 107, 131-137

76. Oyama, S. T., Gott, T., Zhao, H., Lee, Y.-K. Transition metal phosphide hydroprocessing catalysts: A review. Catalysis Today, 2009; 143: 94-107.

77. Zhao, H. Y., Li, D., Bui, P., Oyama, S. T. Hydrodeoxygenation of guaiacol as model compound for pyrolysis oil on transition metal phosphide hydroprocessing catalysts. Applied Catalysis A: General, 2011; 391: 305-310.

78. Li, K., Wang, R., Chen, J. Hydrodeoxygenation of Anisole over Silica-Supported Ni2P, MoP, and NiMoP Catalysts. Energy Fuels, 2011; 25: 854-863.

79. Oyama, S. T. Novel catalysts for advanced hydroprocessing: transition metal phosphides. Journal of Catalysis, 2003; 216: 343-352.

80. Jones SB, Holladay JE, Valkenburg C, Stevens DJ, Walton CW, Kinchin C, Elliott DC, Czernik S: Production of Gasoline and Diesel from Biomass via Fast Pyrolysis, Hydrotreating and Hydrocracking: A Design case. February 2009. Prepared for the U.S. Department of Energy under Contract DE-AC05-76RL01830. February 2009

81. Holmgren J., Marinageli, R., Nair, P., Elliott D. C., Bain R., Consider upgrading pyrolysis oils into renewable fuels. Hydrocarbon Processing, 2008; 87:95-103.

82. Jones S, Meyer P, Snowden-Swan L, Tan e, Dutta A, Jacobson J, Cafferty K: Process design and economics for Conversion of Lignocellulosic Biomass to Hydrocarbon Fuels. Prepared for the US. Department of Energy Bioenergy Technologies Office. PNNL23053, NREL/TP- 5100-61178, November 2013

83. Elliot, D. Advancement of Bio-oil Utilization for Refinery Feedstock. The Washington Bioenergy Research Symposium, Seatlle, November 8, 2010

84. French RJ, Hrdlicka J, Baldwin R: Mild hydrotreating of biomass pyrolysis oils to produce a suitable refinery feedstock, Environmental Progress \& Sustainable Energy, $2010,29,142-150$ 
85. De Miguel Mercader F, Groeneveld MJ, Kersten SRA, Way NWJ, Schaverien CJ, Hogendoon JA: Production of advanced biofuels: Co-processing of upgraded pyrolysis oil in standard refinery unit. Applied Catalysis B: Environmental, 2010, 96, 1-2, 57-66

86. French RJ, Stunkel J, Baldwin RM: Mild Hydrotreatment of Bio-oil: Effect of reaction Severity and fate of Oxygenated Species. Energy and Fuels, 2011, 25, 3266-3274

87. De Miguel Mercader F, Pyrolysis oil upgrading for co-processing in standard refinery units. University of Twente, 2010.

88. Fogassy, G., Thegarid, N., Schuurman, Y., Mirodatos, C. From biomass to bio-gasoline by FCC co-processing: effect of feed composition and catalyst structure on product quality. Energy \& environmental Science, 2011; 4: 5068-5076.

89. De Rezende Pinho, A., de Almeida....M.B.B., Leal Mendes, F., Loureiro Ximenes, V., Casavechia, L.C. Co-processing raw bio-oil and gasoil in an FCC Unit. Fuel Processing Technology, 2015; 131: 159-166.

90. Fogassy, G., Thegarid, N., Schuurman, Y., Mirodatos, C. The fate of bio-carbon in FCC co-processing products. Green Chemistry, 2012; 14: 1367-1371.

91. Domine, M.E., van Veen, A.C., Schuurman, Y., Mirodatos, C. Co-processing of oxygenated biomass compounds and hydrocarbons for the production of sustainable fuel. ChemSusChem, 2008; 1: 179-181.

92. Corma, A., Huber, G.W., Sauvanaud, L., O’Connor, P.O. Processing biomass-derived oxygenates in the oil refinery: Catalytic cracking (FCC) reaction pathways and role of catalyst. Journal of Catalysis, 2007; 247: 307-327.

93. Fogassy, G., Thedarid, N., Toussaint, G., van Veen, A.C., Schuurman, Y., Mirodatos, C. Biomass derived feedstock co-processing with vacuum gas oil for second-generation fuel production in FCC units. Applied Catalysis B: Environmental, 2010; 96: 476-485.

94. Gueudré, L., Chapon, F., Mirodatos, C., Schuurman, Y., Venderbosch, R., Jordan, E., Wellach, S., Miravalles Gutierrez, R. Optimizing the bio-gasoline quantity and quality in fluid catalytic cracking co-refining. Fuel, 2017; 192: 60-70.

95. Thegarid, N. Fogassy, G., Schuurman, Y., Mirodatos, C., Stefanidis, S., Iliopoulou, E.F., Kalogiannis, K., Lappas, A.A. Second-generation biofuels by co-processing catalytic pyrolysis oil in FCC units. Applied Catalysis B: Environmental, 2014; 145: 161-166. 
96. Pinheiro, A., Hudebine, D., Dupassieux, N., Geantet, C. Impact of oxygenated compounds from lignocellulosic biomass pyrolysis oils on gas oil hydrotreatment. Energy \& Fuels, 2009; 23:1007-1014.

97. Bui, V.N., Toussaint, G., Laurenti, D., Mirodatos, C., Geantet, C. Co-processing of pyrolisis bio oils and gas oil for new generation of bio-fuels: Hydrodeoxygenation of guaiacol and SRGO mixed feed. Catalysis Today, 2009; 143: 172-178.

98. Karatzos, S., McMillan, J. D., Saddler, J. N., Summary of the report: "The Potential and Challenges of Drop-in Biofuels”. IEA Bioenergy Task 39, July 2014. ISBN: 978-1910154-09-0.

99. Diebold, J. P., A Review of the chemical and physical mechanisms of the storage stability of fast pyrolysis bio-oils. Report No. NREL/SR-570-27613, National Renewable Energy Laboratory, Golden, CO (2000).

100. Lange JP: Catalysis for biorefineries - performance criteria for industrial operations. Catalysis, Science \& Technology, 2016, 6, 4759

101. Cottam, M.; Bridgwater, A. "Techno-Economic Modeling of Biomass Flash Pyrolysis and Upgrading Systems.” Biomass and Bioenergy; Vol. 7(1), 1994; pp. 267-273.

102. Arthur J. Power and Associates, Inc. Feasibility Study: One thousand tons per day feedstock wood to crude pyrolysis oil plant 542,000 pounds per year using fasty pyrolysis of biomas process. Golden, CO: Prepared by the Solar Energy Research Institute, 1991.

103. Gregoire CE, Bain RL: Technoeconomic analysis of the production of biocrude from wood. Biomass and Bioenergy, 1994, 7, 1-6, 275-283

104. Badger, P., S. Badger, M. Puettmann, P.H. Steele, and J. Cooper. 2011. Technoeconomic analysis: Preliminary assessment of pyrolysis oil production costs and material energy balance associated with a transportable fast pyrolysis system. BioResources 6(1):34-47.

105. Ringer, M., Putsche, V., Scahill, J., 2006. Large-scale Pyrolysis Oil Production: a Technology Assessment and Economic Analysis. NREL, Golden. Technical Report NREL/TP-510-37779 November 2006. Available at: http:/www.osti.gov/bridge.

106. Farag IH, LaClair CE and Barrett C. 2002. Technical, Environmental and Economic Feasibility of Bio-oil in New Hampshire's North County. UNH Project Number 14B316 or ABAN-URI-B043. 
107. Islam, MN and Ani FN. 2000. Technoeconomics of Rice Husk Pyrolysis, Conversion with Catalytic Treatment to Produce Liquid Fuel. Bioresource Technology, Vol. 73, pp. $67-75$.

108. Rogers J. G., Brammer J. G., Estimation of the production cost of fast pyrolysis bio-oil, Biomass Bioenergy, 2012, 36, 208-217.

109. Spath P, Aden A, Eggeman T, Ringer M, Wallace B, Jechure J: Biomass to Hydrogen Production Detailed Design and Economics Utilizing the Battelle Columbus Laboratory Indirectly - Heated Gasifier. Technical Report NREL/TP-510-37408 May 2005.

110. Elliott DC, Hart TR, Neuenschwander GG, Rotness LJ, Zacher AH: Catalytic hydroprocessing of biomass fast pyrolysis bio-oil to produce hydrocarbon products. Environmental Process \& Sustainable Energy, 2009, 441-449

111. Elliott DC, Hart TR, Neuenschwander GG, Rotness LJ, Olarte MV, Zacher AH, Solantausta Y: Catalytic Hydroprocessing of fast pyrolysis Bio-oil from Pine Sawdust. Energy Fuels, 26, 6, 3891-3896

112. De Jong S, Hoefnagels R, Faaij A, Slade R, Mawhood R, Junginger M: The feasibility of short term production strategies for renewable jet fuels - a comprehensive technoeconomic comparison. Biofuels Bioproducts \& Biorefining, 2015, 778-799

113. Arbogast S, Bellman D, Paynter JD, Wykowski J: Advanced biofuels from pyrolysis oils... Opportunities for cost reduction. Fuels Processing Technology, 106, 2013, 518525

114. Lange JP: Fuels and Chemical Manufacturing, Guidelines for Understanding and Minimizing the Production Cost. CATTECH, 2001, 5, 2, 82-95

115. Patel M, Crank M, Dornburg V, Hernann B, Roes L, Husing B, Overbeek L, Terragni F, Rechhia E: Medium and Long Term Opportunities and Risks of the Biotechnological Production of Bulk Chemicals from Renewable Resources. The potential of White Biotechnology. The BREW Project, Utrecht University, September 2006

116. https:/www.statista.com/statistics/311943/agrochemical-market-value-worldwide/.

117. Kiss AA, Lange JP, Schuur B, Brilman DWF, van der Ham AGJ, Kersten SRA: Separation technology - Making a difference in biorefineries. Biomass and Bioenergy, 95, 2016, 296-309 
118. Li, X., Kersten, S. R. A., Schuur, B. Extraction of acetic acid, glycoaldehyde and acetol from aqueous solutions mimicking pyrolysis oil cuts using ionic liquids. Separation and Purification Technology, 2017; 175: 498-505.

119. Hilten RN, Bibens BP, Kastner JR, Das KC, In line esterification of pyrolysis vapors with ethanol improves bio-oil quality. Energy Fuels, 2010, 24 (1), 673-682

120. Lindfords, C., Kuoppala, E., Oasmaa, A., Solantausta, Y., Arpiainen, V. Fractionation of bio-oil. Energy Fuels, 2014; 28: 5785-5791.

121. Westerhof, R.J.M., Oudenhoven, S.R.G., Hu, X., Heeres, H.J., Li, C.-Z., Garcia-Perez, M., Kersten, S.R.A. Biofuel and Methyl Levulinate from Biomass-Derived Fractional Condensed Pyrolysis Oil and Alcohol. Energy Technology, 2017; 5: 205-215.

122. Mullen, C. A., Boateng, A. A., Goldberg, N. M., Lima, I. M., Laird, D. A., Hicks, K.B., Bio-oil and bio-char production from corn cobs and stover by fast pyrolysis. Biomass and Bioeng, 2010; 34: 67-74.

123. Pollard, A.S., Rover, M. R., Brown, R. C. Characterization of bio-oil recovered as stage fractions with unique chemical and physical properties. Journal of Analytical and Applied Pyrolysis, 2012; 93: 129-138.

124. Rover MR, Johnston PA, Jin T, Smith RG., Brown RC, Jarboe L. Production of clean pyrolytic sugars for fermentation. ChemSusChem, 2014; 7: 1662-1668.

125. Chen, T., Deng, C., Liu, R. Effect of Selective Condensation on the Characterization of Bio-oil from Pine Sawdust Fast Pyrolysis Using a Fluidized-Bed Reactor. Energy and Fuels, 2010; 24: 6616-6623.

126. Gooty, A. T., Li, D., Berruti, F., Briens, C. Kraft-lignin pyrolysis and fractional condensation of its bio-oil vapors. Journal of Analytical and Applied Pyrolysis, 2014a; 106: 33-40.

127. Gooty, A. T., Li, D., Briens, C., Berruti, F. Fractional condensation of bio-oil vapors produced from birch bark pyrolysis. Separation and Purification Technology, 2014b; 124: 81-88.

128. Vane, M. L., Alvarez, F. R., Mairal, A. P., Baker, R. W. Separation of Vapor-Phase Alcohol/Water Mixtures via Fractional Condensation Using a Pilot-Scale Dephlegmator: 
Enhancement of the Pervaporation Process Separation Factor. Ind. Eng. Chem. Res., 2004; 43: 173-183.

129. Palla V. S. K. K., Papadikis, K., Gu, S. A numerical model for the fractional condensation of pyrolysis vapours. Biomass and Bioenergy, 2015; 74: 180-192.

130. Gooty, A. T., Fractional Condensation of Bio-Oil Vapors (2012). Electronic Thesis and Dissertation Repository. Paper 979.

131. Johansson, A.-C., Iisa, K., Sandström, L., Ben, H., Pilath, H., Deutch, S., Wiinikka, H., Öhrman, O. G. W. Fractional condensation of pyrolysis vapors produced from Nordicfeedstocks in cyclone pyrolysis. Journal of Analytical and Applied Pyrolysis, 2017; 123: 244-254.

132. Ali, N., Uemura, Y., Afif, H. A., Osman, N. B., Omar, W. N., Abdullah, B., Tsutsui, T. Effect of Operating Conditions and Fractional Condensation on Pyrolytic Products. Journal of the Japan Institute of Energy, 2013; 92: 1014-1020.

133. Williams, P. T., Brindle, A. J. Temperature selective condensation of tyre pyrolysis oils to maximise the recovery of single ring aromatic compounds. Fuel, 2003; 82: 1023-1031.

134. Westerhof, R. J. M., Kuipers, N. J. M., Kersten, S. R. A., van Swaaij, W. P. M. Controlling the water content of biomass fast pyrolysis oil. Ind. Eng. Chem. Res., 2007; 46: $9238-9247$.

135. Westerhof, R. J. M., Brilman, D. W. F., Garcia-Perez, M., Wang, Z., R. G. Oudenhoven, S., P. M. van Swaaij, W., R. A. Kersten, S. Fractional Condensation of Biomass Pyrolysis Vapors. Energy and Fuels, 2011; 25: 1817-1829.

136. Brown RC, Jones ST, Pollard A: Bio-oil fractionation and condensation US Patent $9,611,439,2017$

137. Wang S, Gu Y, Liu Y, Guo Z, Luo Z, Cen K: Separation of bio-oil by molecular distillation. Fuel Processing Technology, 2009, 90, 5, 738-745

138. Garcì-Pérez M., Chaala A., Roy C., Vacuum pyrolysis of sugarcane bagasse. Journal of Analytical and Applied Pyrolysis, 2002; 65: 111-136.

139. Wang C, Hu Y, Chen Q, Lv C, Jia S: Bio-oil upgrading by reactive distillation using ptoluene sulfonic acid catalyst loaded on biomass activated carbon. Biomass and Bioenergy, 2013, 56, 405-411 
140. Capunitan JA, Capareda SC: Characterization and separation of corn stover bio-oil by fractional distillation. Fuel, 2013, 112, 60-73

141. Zhang L, Liu R, Yin R, Mei Y: Upgrading of bio-oil from biomass fast pyrolysis in China: A review. Renewable and Sustainable Energy Reviews. 2013, 24, 66-77

142. Elkasabi Y, Mullen CA, Boateng AA; Distillation and Isolation of Commodity Chemicals from Bio-oil Made by Tail Gas Reactive Pyrolysis. ACS Sustainale Chem. Eng., 2014, 2 (8), 2042-2052

143. Elkasabi Y, Mullen CA, Jackson MA, Boateng AA: Characterization of fast pyrolysis bio-oil distillation residues and their potential applications. Journal of Analytical and Applied Pyrolysis, 2015, 114, 179-186

144. Zhu X, Zhang Y, Ding H, Huang L, Zhu X: Comprehensive study on pyrolysis and copyrolysis of walnut shell and bio-oil distillation residue. Energy Conversion and Management. Energy Convesion and Management 168, 2018, 178-187

145. Zheng J-L, Wei Q: Improving the quality of fast pyrolysis bio-oils by reduced pressure distillation. Biomass and Bioenergy 35, 2011, 1804-1810

146. Boucher, M. E., Chaala, A., Pakdel, H., Roy, C. Bio-oils obtained by vacuum pyrolysis of softwood bark as a liquid fuel for gas turbines. Part II: Stability and ageing of bio-oil and its blends with methanol and a pyrolytic aqueous phase. Biomass and Bioenergy, 2000; 19: $351-361$.

147. Oasmaa A, J. Korhonen, E. Kuoppala, An approach for stability measurement of woodbased fast pyrolysis bio-oils, Energy Fuels 25 (2011) 3307-3313.

148. Zhang X-S, Yang G-X, Jiang H, Liu W-J, Ding H-S: Mass production of chemicals from biomass derived oil by directly atmospheric distillation coupled with co-pyrolysis. Scientific report, 2013a, 3: 1120/ DOI 10.1038/srep01120

149. Elkasabi Y, Boateng AA, Jackson MA: Upgrading of bio-oil distillation bottoms into biorenewable calcinated coke. Biomass and Bioenergy, 2015a, 81, 415-423

150. Elkasabi YM, Boateng AA, Mullen CA: Methods of Producing Calcinated Coke from Bio-oil and Calcinated Coke Produced Thereby. US Patent Application US201601772081 
151. Guo Z, Wang S, Gu Y, Xu G, Luo Z: Separation characteristics of biomass pyrolysis oil in molecular distillation. Separation and Purification Technology, 2010, 76, 1, 1, $52-57$

152. Wang S, Wang Y, Cai Q, Wang X, Jin H, Luo Z: Multi-step separation of monophenols and pyrolytic lignins from the water-insoluble phase of bio-oil. Separation and Purification Technology, 2014, 122, 10, 248-255

153. Corredores, M. M. R., Iglesias, V. S. Production of renewable fuels, U.S. Patent 8,647,398 B2, Feb. 11, 2014a.

154. Corredores, M. M. R., Iglesias, V. S. Production of renewable fuels, U.S. Patent $8,853,484$ B2, Oct. 7, 2014b.

155. Corredores, M. M. R., Iglesias, V. S. Production of renewable fuels, U.S. Patent $8,888,871$ B2, Nov. $18,2014 \mathrm{c}$.

156. Corredores, M. M. R, Iglesias, V. S. Production of renewable fuels, U.S. Patent 8,968,670 B2, Mar. 3, 2015a.

157. Corredores, M. M. R., Iglesias, V. S. Production of renewable fuels, U.S. Patent 9,062,264 B2, Jun. 23, $2015 b$.

158. Corredores, M. M. R., Iglesias, V. S. Production of renewable fuels, U.S. Patent 9,447,338 B2, Sep. 20, 2016.

159. Corredores, M. M. R., Tong, X., Sorrells, J., Anderson, J. R., Bio-oil Fractionation, U.S. Patent 9,327,208 B2, May 3, 2016.

160. Guo X, Wang S, Guo Z, Liu Q, Luo Z, Cen K: Pyrolysis characteristics of bio-oil fractions separated by molecular distillation. Applied Energy, 2010, 87, 2892-2898

161. Guo Z, Wang S, Xu G, Cai Q, Zhu L: Upgrading of bio-oil molecular distillation fraction with solid acid catalysts. BioResources, 2011, 6, 3,

162. Guo Z, Wang S, Zhu Y, Luo Z, Cen K: Separation of acetic compounds for refining biomass pyrolysis oil. Journal of Fuel Chemistry and Technology, 37, 1, 2009, 49-52

163. Wang S, Cai Q, Wang X, Zhang L, Wang Y, Luo Z: Biogasoline production from the cocracking of the distilled fractions of bio-oil and ethanol. Energy \& Fuels, 2014a, 28 (1), $115-122$ 
164. Wang Y, Wang S, Leng F, Chen J, Zhu L, Luo Z: Separation and characterization of pyrolytic lignins from the heavy fraction of bio-oil by molecular distillation. Separation and Purification Technology, 2015, 152, 25, 123-132

165. Junming X., Jianchun J., Yunjung S., Yanju L., Bio-oil upgrading by means of ethyl ester production in reactive distillation to remove water and to improve storage and fuel characteristics. Biomass and Bioenergy, 2008; 32:1056-1061.

166. Vitazari CR, Meindersma GW, de Han AB: Water extraction of pyrolysis oil: The first step for the recovery of renewable chemicals. Bioresources Technology, 2011, 102, 14, 7204-7210

167. Park K, Ren S, Yiacoumi S, Ye P, Borole AP, Tsouris C: Separation of Switchgrass Biooil by Water/Organic Solvent addition and pH adjustment. Energy Fuels, 2016, 30 (3), 2164-2173

168. Mohan, D., Pittman, C. U., Steele, P. H., Pyrolysis of wood/biomass for bio-oil: A critical review. Energy Fuels, 2006; 20: 848-889.

169. Shriner, R. L.; Fuson, R. C.; Curtin, D. Y. The Synthetic Identification of Organic Compounds: A Laboratory Manual, 4th Edition; Wiley: New York, 1964

170. Mourant D, Yang D-Q, Lu X, Roy C: Anti-fungal properties of the pyroligneous liquours from the pyrolysis of softwood bark. Wood and Fiber Science, No. 3, 2005

171. Oasmaa, A.; Kuoppala, E.; Gust, S.; Solantausta, Y. Fast Pyrolysis of Forestry Residue. 1. Effect of Extractives on Phase Separation of Pyrolysis Liquids. Energy Fuels 2003, 17 (1), 1-12.

172. Das, P.; Sreelatha, T.; Ganesh A. Bio-oil from pyrolysis of cashew nut shellcharacterization and related properties. Biomass Bioenergy 2004, 27, 265-275.

173. Sipilä, K., Kuoppala, E., Fagernäs, L., Oasmaa, A., Characterization of biomass-based flash pyrolysis oils. Biomass and Bioenergy, 1998; 14(2):103-13.

174. Amen-Chen, C., Pakdel, H., Roy, C. Separation of phenols from eucalyptus wood tar. Biomass and Bioenergy, 1997; 13: 25-37.

175. Mahfud F.H., van Geel F.P, R.H. Venderbosch, H.J. Heeres, Acetic acid recovery from fast pyrolysis oil. An exploratory study on liquid-liquid reactive extraction using aliphatic tertiary amines, Sep. Sci. Technol. 43, 2008, 3056-3074. 
176. Murwanashyaka, J. N., Pakdel, H., Roy, C. Seperation of syringol from birch woodderived vacuum pyrolysis oil. Separation and Purification Technology, 2001; 24: 155165.

177. Ren, S., Ye, X. P., Borole, A. P. Separation of chemical groups from bio-oil water-extract via sequential organic solvent extraction. Journal of Analytical and Applied Pyrolysis, 2017; 123: 30-39;

178. Oasmaa, A.; Kuoppala, E.; Solantausta, Y. Fast Pyrolysis of Forestry Residues. 2. Physicochemical Composition of Product Liquid. Energy Fuels 2003a, 17 (2), 433-443.

179. Oasmaa, A.; Kuoppala, E. Fast Pyrolysis of Forest Residue. 3. Storage Stability of Liquid Fuel. Energy Fuels 2003, 17 (4), 1075-1084

180. Kumar S, Lange J-P, van Rossum G, Kersten SRA: Bio-oil fractionation by temperatureswing: Principles and Application. Biomass and Bioenergy, 83 (2015), 96-104

181. Chan YH, Yusup S, Quitain AT, Uemura Y, Loh SK: Fractionation of pyrolysis oil via supercritical carbon dioxide extraction: Optimization study using response surface methodology (RSM) Biomass and Bioenergy 107, 2017, 155-163

182. Rout PK, Naik MK, Naik SN, Goud VV, Das LM, Dalai AK: Supercritical CO2 fractionation of Bio-oil from Mixed Biomass of Wheat and Wood Sawdust. Energy Fuels, 2009, 23 (12), 6181-6188

183. Feng Y, Meier D: Supercritical carbon dioxide extraction of fast pyrolysis oil from softwood. The Journal of Supercritical Fluid. 2017, 128, 6-17

184. Naik S, Goud VV, Rout PK, Dalai AK: Supercritical CO2 fractionation of bio-oil produced from wheat-hemlock biomass. Bioresource Technology, 2010, 101, 19, 76057513

185. Wang J, Cui H, Wei S, Zhou S, Wang L, Li Z, Yi W: Separation of Biomass Pyrolysis Oil by Supercritical CO2 Extraction, Smart Grid and Renewable Energy, 2010, 1, 98-107

186. Feng Y, Meier D: Extraction of value-added chemicals from pyrolysis liquids with supercritical carbon dioxide. Journal of Analytical and Applies Pyrolysis. 2015, 113, 174185. 
187. Feng Y, Meier D: Comparison of supercritical CO2 liquid, liquid CO2 and solvent extraction of chemicals from a commercial slow pyrolysis liquid of beech wood. Biomass and Bioenergy, 2016, 85, 346-354

188. Cheng T, Han Y, Zhang Y, Xu C: Molecular composition of oxygenated compounds in fast pyrolysis bio-oil and its supercritical fluid extracts. Fuel, 2016, 172, 15, 49-57

189. Stanford JP, Hall PH, Rover MR, Smith RG, Brown RC: Separation of sugars and phenols from the heavy fraction of bio-oil using polymeric resin adsorbents. Separation and Purification Technology, 2018, 194, 170-180

190. Victor-Ortega M, Ochando-Pulido J, Martinez-Ferez A: Phenols removal from industrial effluents through novel polymeric resins: kinetics and equilibrium studied. Sep. Purif. Technol. 160, 2016, 136-144

191. Huang J, Crandford RJ, Matsuura T, Roy C: Development of polyimide membranes for the separation of water vapor from organic compounds. 2002, 85, 1, 139-152

192. Huang J, Cranford RJ, Matsuura T, Roy C: Water vapor sorption and transport in dense polyimide membranes. Applied Pyrolysis. 2003, 87, 14, 2306-2317

193. Cranford RJ, Darmstadt H, Yang J, Roy C: Polyetherimede/polyvinylpyrrolidone vapor permeation membranes. Physical and chemical characterization. Journal of membrane Science, 1999, 155, 2, 231-240.

194. Sano T, Ejiri S, Yamada K, Kawakami Y, Yanagoshita H: Separation of acetic acid-water mixtures by pervaporation through silicate membrane. 1997, 123, 2, 22, 225-233

195. Yeom C-Y, Lee K-H: Pervaporation separation of water-acetic acid mixtures thorugh poly(vinyl alcohol) membranes crosslinked with glutaraldehyde. Journal of Membrane Science, 1996, 109, 2, 24, 257-265

196. Alghezawi N, Sanli O, Aras L, Asman G: Separation of acetic acid-water mixtures through acrylonitrile grapfted poly(vinyl alcohol) membranes by pervaporation. Chemical Engineering and processing: process Intensification. 2005, 44, 1, 51-58

197. Huang J, Cranford RJ, Matsuura T, Roy C: Sorption and transport behavior of water vapor in dense and asymmetric polymide membranes. 2004, 241, 2, 187-196

198. Huang J, Cranford RJ, Matsuura T, Roy C: Water vapor permeation properties of aromatic polymides. Journal of Membrane Science, 2003a, 215, 1-2, 129-140 
199. Huang RYM, Yeom CK: Pervaporation separation of aqueous mixtures using crosslinked polyvinyl alcohol membranes. III. Permeation of acetic acid-water mixtures. Journal of Membrane Science, 1991, 58, 1, 33-47

200. Li S, Tuan VA, Noble RD, Falconer JL: A Ge-Substituted ZSM-5 Zeolite Membrane for separation of acetic acid from water. Ind. Eng. Chem. Res., 2001, 40, 6165-6171

201. Grzenia DL, Schell DJ, Wickramasinghe R: Membrane extraction for removal of acetic acid from biomass hydrolysates. Journal of Membrane Science, 2008, 322, 1, 189-195

202. Dickey LC, Boateng AA, Goldberg NM, Mullen CA, Mihalcik D: Condensation of Acetol and Acetic Acid Vapor and Nitrogen Using Sprayed Aqueous Liquid. Ind. Eng. Chem. Res. 2012, 51, 5067-5072

203. Tumbalam-Gooty A, Li D, Briens C, Berruti F: Fractional condensation of bio-oil vapors produced from birch bark pyrolysis. Separation and Purification technology, 2014, 124, $18,81-88$

204. Tumbalam-Gooty A: Fractional Condensation of Bio-oil Vapors, 2012 MSc Thesis, The University of Western Ontario, http://ir.lib.uwo.ca/etd/979/

205. Yin R, Liu R, Mei Y, Fei W, Sun X: Characterization of bio-oil and biochar obtained from sweet sorghum bagasse fat pyrolysis with fractional condensers. Fuel, 112, 2013, 96-104

206. Kim P, Weaver S, Noh K, Labbe N: Characteristics of Bio-oils Produced by an intermediate Semipilot Scale Pyrolysis Auger Reactor Equipped with Multistage Condensers, Energy \& Fuels, 2014, 28, 6966-6973

207. Klar M, Rule A; The Technology of Wood Distillation. Chapman \& Hall, London 1925

208. Ijmker, H. M., Gramblicka, M., Kersten, S. R. A., van der Ham, A. G. J., Schuur, B. Acetic acid extraction from aqueous solutions using fatty acids. Separation and Purification Technology, 2014; 125: 256-263.

209. Teella, A., Huber, G. W., Ford, D. M. Separation of acetic acid from the aqueous fraction of fast pyrolysis bio-oils using nanofiltration and reverse osmosis membranes. Journal of Membrane Science, 2011; 378: 495-502.

210. Sukhbaatar, B., Steele, P. H., Ingram, L. L., Kim, M. G. An exploratory study on the removal of acetic and formic acids from bio-oil. BioResources, 2009; 4: 1319-1329. 
211. Chien LI, Zeng K-L, Chao H-Y, Liu JH: Design and control of acetic acid dehydration system via heterogeneous azeotropic distillation. Chemical Engineering Science, 2004, $59,21,4547-4567$

212. Wang SJ, Kejin Huang: Design and control of acetic acid dehydration system via azeotropic distillation using p-xylane as an entrainer. Chemical Engineering and processing 60 (2012), 65-76

213. Lei Z, Li Ch, Li Y, Chen B: Separation of acetic acid and water by complex extractive distillation. Separation and Purification Technology 36 (2004) 131-138

214. Sartorius R, Stapf: Process for preparing technically pure acetic acid by extractive distillation. United States Patent, 3,951,755, April, 20, 1976

215. Saha B, Chopade SP, Mahajani SM: Recovery of dilute acetic acid through esterification in a reactive distillation column. Catalysis Today 2000, 60, 1-2, 147-157

216. Tang Y-T, Chen Y-W, Huang HP, Yu CC, Hung S-B, Lee MJ: Design of Reactive Distillations for Acetic Acid Esterification. AIChE Journal, 2005, 51, 6, 1683 -

217. Xu Z, Afacan A, Chuang KT: Removal of Acetic acid from water by catalytic distillation. Part 1: Experimental Studies. The Canadian Journal of Chemical Engineering, 1999, 77, 4, 676-681

218. Hong Y.K., Hong W.H., Removal of acetic acid from aqueous solutions containing succinic acid and acetic acid by tri-n-octylamine, Sep. Purif. Technol. 42 (2005) 151157.

219. Weng Y-H, Wei H-J, Tsai W-H, Chen W-H, Wei T-Y, Hwang W-S, Wang C-P, Huang C-P: Separation of acetic acid from xylose by nanofiltration. Separation and Purified Technology, 2009, 67, 1, 19, 95-102

220. Mohamad, M. H., Awang, R., Yunus, W. M. Z. W. A Review of acetol: application and production. American Journal of Applied Sciences, 2011; 8: 1135-1139.

221. Li X; Ionic liquids in separations: applications for pyrolysis oil and emulsion systems. $\mathrm{PhD}$ dissertation. University of Twente, 2017

222. Wijesekera TP, Bhinde MV: Method for removal of acetol from phenol. US Patent: US 7002048 B2 
223. Vitasari, C. R., Meindersma, G. W., de Haan, A. B. Laboratory scale conceptual process development for the isolation of renewable glycolaldehyde from pyrolysis oil to produce fermentation feedstock. Green Chem., 2012a; 14: 321-325.

224. Stradal, J. A., Underwood, G. L. PROCESS FOR PRODUCING HYDROXYACETALDEHYDE United States Patent, 5393542, 1995

225. Vitasari, C. R., Meindersma, G. W., de Haan, A. B. Renewable glycolaldehyde isolation from pyrolysis oil-derived aqueous solution by reactive extraction with primary amines. Separation and Purification Technology, 2012b; 95: 103-108.

226. Babíc, K., van der Ham, A. G. J., de Haan, A. B. Reactive extraction of aldehydes from aqueous solutions with Primene ${ }^{\circledR}$ JM-T. Separation and Purification Technology, 2009; 66: 525-531.

227. Stradal, J. A., Underwood, G. L. Process for producing hydroxyacetaldehyde, U.S. Patent 5,252,188 B2, Oct. 12, 1993.

228. Oasmaa, A., Kuoppala, E. Solvent Fractionation Method with Brix for Rapid Characterization of Wood Fast Pyrolysis Liquids. Energy \& Fuels, 2008; 22: 4245-4248.

229. Lian, J., Chen, S., Zhou, S., Wang, Z., O’Fallon, J., Li, C.-Z., Garcia-Perez, M. Separation, hydrolysis and fermentation of pyrolytic sugars to produce ethanol and lipids. Bioresource Technology, 2010; 101: 9688-9699.

230. Bennett, N. M., Helle, S. S., Duff, S. J. B. Extraction and hydrolysis of levoglucosan from pyrolysis oil. Bioresource Technology, 2009; 100: 6059-6063.

231. Mourant, D., Wang, Z., He, M., Wang, X. S., Garcia-Perez, M. Mallee wood fast pyrolysis: Effects of alkali and alkaline earth metallic species on the yield and composition of bio-oil. Fuel, 2011; 90: 2915-2922.

232. Pecha B, Arauzo P, Garcia-Perez M: Impact of combined acid washing and acid impregnation on the pyrolysis of Douglas fir wood. Journal of Analytical and Applied Pyrolysis, 114, 2015, 127-137

233. Dobele, G., Dizhbite, T., Rossinskaja, G., Telysheva, G., Meier, D., Radtke, S., Faix, O. Pre-treatment of biomass with phosphoric acid prior to fast pyrolysis: A promising method for obtaining 1,6-anhydrosaccharides in high yields. J. Anal. Appl. Pyrolysis, 2003; 68-69: 197-211. 
234. Patwardhan, P. R., Satrio, J. A., Brown, R. C., Shanks, B. H. Influence of inorganic salts on the primary pyrolysis products of cellulose. Bioresource Technology, 2010; 101: 4646-4655.

235. Esterer, A. K. Separating levoglucosan and carbohydrate acids from aqueous mixtures containing the same-by solvent extraction. U.S. Patent 3,309,356, Mar. 14, 1967.

236. Moens, L. Isolation of levoglucosan from pyrolysis oil derived from cellulose. U.S. Patent 5,371,212, Dec. 6, 1994.

237. Li Q, Steele PH, Mitchell B, Ingram LI, Yu F: The addition of Water to Extract Maximum Levoglucosan from the Bio-oil produced via fast pyrolysis of pretreated Loblolly Pinewood. BioResources, 2013, 8(2), 1868-1880

238. Qin, F., Cui, H., Yi, W., Wang, C. Upgrading the water-soluble fraction of bio-oil by simultaneous esterification and acetalization with online extraction. Energy and Fuels, 2014; 28: 2544-2553.

239. De Wild P, Reith H, Heeres E: Biomass pyrolysis for chemicals, Biofuels, 2011, 2, 185208

240. Zilnik, L. F., Jazbinsek, A. Recovery of renewable phenolic fraction from pyrolysis oil. Separation and Purification Technology, 2012; 86: 157-170

241. Yang, H.-M., Zhao, W., Norinaga, K., Fang, J.-J., Wang, Y.-G., Zong, Z.-M. Separation of phenols and ketones from bio-oil produced from ethanolysis of wheat stalk. Separation and Purification Technology, 2015; 152: 238-245.

242. Shashkov, M. V., Sidelnikov, V. N. Separation of phenol-containing pyrolysis products using comprehensive two-dimensional chromatography with columns based on pyridinium ionic liquids. J Anal Bioanal Tech, 2016; 7:313.

243. Salema, A. A. Extraction of phenolic compounds from crude pyrolysis oil. Journal of Postdoctoral Research, 2014; 2: 47-50.

244. Li, J., Wang, C., Yang, Z. Production and separation of phenols from biomass-derived bio-petroleum. Journal of Analytical and Applied Pyrolysis, 2010; 89: 218-224.

245. Kim, J.-S. Production, separation and applications of phenolic-rich bio-oil - A review. Bioresource Technology, 2015; 178: 90-98. 
246. Guo, W., Hou, Y., Wu, W., Ren, S., Tian, S., Marsh, K. N. Separation of phenol from model oils with quaternary ammonium salts via forming deep eutectic solvents. Green Chem., 2013; 15: 226-229.

247. Fu D, Farag S, Chaouki J, Jessop PG: Extraction of phenols from lignin microwavepyrolysis oil using a switchable hydrophilicity solvent. Bioresource Technology, 2014, $154,101-108$

248. Bai, X., Kim, K. H., Brown, R. C., Dalluge, E., Hutchinson, C., Lee, Y. J., Dalluge, D. Formation of phenolic oligomers during fast pyrolysis of lignin. Fuel, 2014; 128: 170179.

249. Shah Z, Renato CV, Marco AC, Rosangela DS. Separation of Phenol from Bio-oil Produced from Pyrolysis of Agricultural Wastes. Mod Chem Appl, 2017; 5: 199.

250. Wang, L. Sustainable bioenergy production. CRC Press, Apr. 18. 2014; 583 pages.

251. Sanghi, R., Singh, V. Green chemistry for environmental remediation. John Wiley \& Sons, Jan. 20, 2012; 800 pages.

252. Chiaramonti, D., Bonini, M., Fratini, E., Tondi, G., Gartner, K., Bridgwater, A. V., Grimm, H.P., Soldaini, I., Webster, A., Baglioni, P. Development of emulsions from biomass pyrolysis liquid and diesel and their use in engines-Part 2: tests in diesel engines. Biomass and Bioenergy, 2003a; 25: $101-111$.

253. Chiaramonti, D., Bonini, M., Fratini, E., Tondi, G., Gartner, K., Bridgwater, A. V., Grimm, H.P., Soldaini, I., Webster, A., Baglioni, P. Development of emulsions from biomass pyrolysis liquid and diesel and their use in engines-Part 1: emulsion production. Biomass and Bioenergy, 2003b; 25: 85 - 99.

254. Ikura M, Stancielescu M, Hogan E: Emulsification of pyrolysis derived bio-oil in diesel fuel. Biomass and Bioenergy, 2003, 24, 3, 221-232

255. Jiang X, Ellis N: Upgrading Bio-oil through Emulsification with Biodiesel: Mixture Production. Energy \& Fuels, 2010, 24 (2), 1358-1364

256. Jiang, X., Ellis, N. Upgrading bio-oil through emulsification with biodiesel: thermal stability. Energy Fuels, 2010; 24: 2699-2706.

257. Qi, Z., Jie, C., Tiejun, W., Ying, X. Review of biomass pyrolysis oil properties and upgrading research. Energy Conversion and Management, 2007; 48: 87-92. 
258. Garcia-Perez M, Shen J, Wang XS, Li C-Z: Production and fuel properties of fast pyrolysis oil/bio-diesel blends. Fuel Processing Technology, 2010, 91, 3, 296-305

259. Chiaramonti D, Oasmaa A, Solantausta Y: Power generation using fast pyrolysis liquids from biomass. Renewable and Sustainable Energy Reviews, 2007, 11, 6, 1056-1086

260. San Miguel G, Makibar J, Fernandez-Akarragi AR: New Advances in the Fast Pyrolysis of Biomass, Journal of Biobased Materials and Bioenegry, 2012, 6, 2, 193-203

261. Garcia-Perez M, Adams TT, Goodrum JW, Das KC, Geller DP: DSC studies to evaluate the impact of bio-oil on cold flow properties and oxidation stability of biodiesel. Bioresource Technology, 2010, 101, 15, 6219-6224

262. Gunawan R, Li X, Larcher A, Hu X, Mourant D, Chaiwat W, Wu H, Li C-Z: Hydrolysis and glycosidation of sugars during the esterification of fast pyrolysis bio-oil. Fuel, 95, 2012, 146-151

263. Miao S, Shanks BH: Esterification of biomass pyrolysis model acids over sulfuric acidfunctionalized mesoporous silicas. Applied Catalysis A: General, 2009, 359, 1-2, 113120

264. Moens L, Black SK, Myers MD, Czernik S: Study of the Neutralization and Stabilization of Mixed Hardwood Bio-oil. Energy Fuels, 2009, 23, 5, 2695-2699

265. Peng J, Chen P, Lou H, Zheng X: Catalytic upgrading of bio-oil by HZSM-5 in sub- and super-critical ethanol. Bioresource Technology, 2009, 100, 13, 3415-3418

266. Li X, Gunawan R, Lievens C, Wang Y, Mourant D, Wang S, Wu H, Garcia-Perez M, Li C-Z: Simultaneous catalytic esterification of carboxylic acids and acetalisation of aldehydes in a fast pyrolysis bio-oil from mallee biomass. Fuel, 2011, 90, 7, 2530-2537

267. Wang JJ, Chang J, Fan J: Upgrading of Bio-oil by Catalytic Esterification and Determination of Acid Number for Evaluating Esterification Degree. Energy \& Fuels, 2010, 24 (5), 3251-3255

268. Wang JJ, Chang J, Fan J: Catalytic esterification of bio-oil by ion exchange resins. Journal of Fuel Chemistry and Technology, 2010, 2010, 38, 5, 560-564

269. Sotirchos SV, Smith AR: Experimental investigation of the decomposition and calcination of calcium-enriched bio-oil. Ind. Eng. Chem. Res. 2003, 42 (10), 2245-2255 
270. Wang, S., Luo, Z. Pyrolysis of Biomass. Walter de Gruyter GmbH \& Co KG, Jan. 1, 2017; 268 pages.

271. Lin B-J, Chen W-H, Budzianowski W, Hsieh C-T, Lin P-H: Emulsification analysis of bio-oil and diesel under various combination of emulsifiers. Applied Energy, 2016, 178, $746-757$

272. Ikura M., Stanciulescu M., Hogan E., Emulsification of pyrolysis derived bio-oil in diesel fuel. Biomass and Bioenergy, 2003; 24: 221-32.

273. Guo, Z., Wang, S., Wang, X. Emulsification of bio-oil heavy fraction with diesel by mechanical and ultrasonic technologies. Applied Mechanics and Materials, 2013a; 316317: 1133-1137.

274. Yin, Q., Wang, S., Li, X., Guo, Z., Gu, Y. Review of bio-oil upgrading technologies and experimental study on emulsification of bio-oil and diesel. 2010 International Conference on Optoelectronics and Image Processing, China.

275. Jiang, X., Ellis, N. Upgrading bio-oil through emulsification with biodiesel: mixture production. Energy Fuels, 2010a; 24: 1358-1364.

276. Zhang, L., Kong, S.-C. Multicomponent vaporization modeling of bio-oil and its mixtures with other fuels. Fuel, 2012; 95: 471-480.

277. Boucher ME, Chaala A, Roy C: Bio-oils obtained by vacuum pyrolysis of softwood bark as a liquid fuel for gas turbines. Part I: Properties of bio-oil and its blends with methanol and a pyrolytic aqueous phase. Biomass and Bioenergy, 19, 2000a, 337-350

278. Zhang, M., Wu, H. Fuels mixtures from crude glycerol, the bio-oil-water-solublefraction, and biochar for stationary applications. Energy Fuels, 2016; 30: 8419-8424.

279. Naranjo, S., Miguel, G. S., Sanz, F. Compatibility of fast pyrolysis bio-oil/bioethanol blends with plastic polymers. Proceedings of the 13th International Conference on Environmental Science and Technology. Athens, Greece, 5-7 September 2013.

280. Zhang, M. Properties of bio-oil based fuel mixtures: biochar/bio-oil slurry fuels and glycerol/bio-oil fuel blends. PhD thesis, Curtin University, Bentley, Austrália Ocidental, Austrália.

281. Krutof, A., Hawboldt, K. Blends of pyrolysis oil, petroleum, and other bio-based fuels: a review. Renewable and Sustainable Energy Reviews, 2016; 59: 406-419. 
282. Li X, Gunawan R, Lievens C, Wang Y, Mourant D, Wang S, Wu H, Garcia-Perez M, Li C-Z: Simultaneously catalytic esterification of carboxylic acids and acetalisation of aldehydes in fast pyrolysis bio-oil from mallee biomass. Fuel, 2011a, 90, 7, 2530-2537

283. Zhang Q, Xu Y, Li Y, Wang T, Zhang Q, Ma L, He M, Li K: Investigation on the esterification by using supercritical ethanol for bio-oil upgrading. Applied Energy, 2015, $160,15,633-640$

284. Wang S, Guo Z, Cai Q, Guo L: Catalytic conversion of carboxylic acids in bio-oil for liquid hydrocarbons production. Biomass and Bioenergy, 2012, 45, 138-143

285. Prajitno H, Insyani R, Park J, Ryu C, Kim J: Non-catalytic upgrading of fast pyrolysis bio-oil in supercritical ethanol and combustion behavior of the upgraded oil. Applied Energy, 2016, 172, 12-22

286. Xu J, Jiang J, Dai W, Zhang T, Xu Y: Bio-oil upgrading by means of Ozone Oxidation and Esterification to Remove water and to improve fuel characteristics. Energy Fuels, 2011, 25 (4), 1798-1801

287. Xiong WM, Zhu MZ, Deng L, Fu Y, Guo QX: Esterification of Organic acid in Bio-oil using Acidic Ionic Liquid Catalysts. Energy Fuels, 2009, 23 (4), 2278-2283

288. Oehr, K. Acid emission reduction. U. S. Patent 5,458,803, Oct. 17, 1995.

289. Freel, B.; Graham, R. G. Bio-oil Preservatives. U.S. Patent 6,485,841, Nov. 26, 2002.

290. Mohan D, Shi J, Nicholas D, Pittman CU, Steele PH, Cooper J: Fungicidal values of biooils and their ligninrich fractions obtained from wood/bark fast pyrolysis. Chromosphere, 2008, 71, 3, 456-465

291. Radlein, D.; Piskorz, J.; Majerski, P. Method of producing slowrelease nitrogenous organic fertilizer from biomass. U.S. Patent 5,676,727, Oct. 14, 1997.

292. Bridgwater, A. V. Slow release fertilizers by pyrolytic recycling of agricultural wastes. PyNe Newsletter. 2000; 10(9).

293. http://www.forestprod.org/biomass09steele.pdf

294. Bedmutha R, Booker CJ, Ferrante K, Briens C, Berruti F, Yeung KKC, Scott I, Conn K: Insecticidal and bactericidal characteristics of the bio-oil from the fast pyrolysis of coffee grounds. Journal of Analytical and Applied Pyrolysis 90, 2011, 224-231 
295. Booker C, Bedmutha R, Vogel T, Gloor A, Xu R, Ferrante L, Yeung KKC, Scott IM, Conn KL, Berruti F, Briens C: Experimental Investigations into the Insecticidal, Fungicial and Bactericidal Properties of Pyrolysis Bio-oil from Tabbacco Leaves Using a Fluidized Bed Pilot Plant. Ind. Eng. Chem. Res. 2010, 49, 20, 10074-10079

296. Kim DH, Seo HE, Lee S-C-L, Lee K-Y: Effects of wood vinager mixted with insecticides on the mortalities of nalaparvata lugens and laodelphax striatellus (homoptera: Delphacidae). Animal cell and Systems. Vol. 12, 2008, Issue 1.

297. Wititsiri S: Production of wood vinagers from coconut shells and additional metarials for control of termite workers, Odontotermes sp., and striped mealy bugs, Ferrisia virgate. Singklanakin J. Sci. Technol. 33 (3), 349-354, 2011

298. Oramahi HA, Yoshimura T: Antifungal and antitermitic activities of wood vinager from vitex pubescens Vahl. J. Wood Sci, 2013, 59: 344-350

299. Pangnakorn U, Watanasorn S, Kuntha C, Chuenchooklin S: Application of wood vinager to germented liquid bio-fertilizer for organic agriculture on soybean. Asian Journal of Food and Agro Industry, 2009, S189-S196

300. Pangnakorn U, Kanlaya S, Kuntha C: Efficiency of Wood Vinager and Extractants from some medicinal plants on insect control. Advances in Environmental Biology, 5 (2), 477482, 2011

301. Mungkunkamchao T, Kesmala T, Pimratch S, Toomsan B, Jothityangkoon D. Wood vinegar and fermented bioextracts: Natural products to enhance growth and yield of tomato (Solanum lycopersicum L.). Scientia Horticulturae. 2013, 154, 66-72.

302. Mela E, Arkeman Y, Noor E, Achsani NA, Potential products of coconut shell wood vinager. Research Journal of Pharmaceutical, Biological and Chemical Sciences, 2013, 4, 4, 1480-1493.

303. Pangnakorn U, Kanlaya S, Kuntha C: effect of wood vinager for controlling on housefly (Musca domestica L). International Journal of Agricultural and Biosystems Engineering, Vol.6, 5, 2012

304. Satoko I, Toshimitsu H, Yuji I, Dietrich M: Components and Anti-fungal efficiency of wood-vinager liquor prepared under different carbonization conditions. Wood research. Bulletin of the wood research institute Kyoto University (2000), 87, 34-36 
305. Shiny KS, Remadevi OK: Evaluation of termiticidal activity of coconut shell oil and its comparison to commercial wood preservatives. Eur. J. Wood Prod., 2014, 72: 139-141

306. Tiilikkala K, Fagernas L, Tiilikkala J: History of Use of Wood Pyrolysis Liquids as Biocide and Plant Protection Product. The Open Agricultural Journal, 2010, 4, 111-118.

307. Hagner M: Potential of the slow pyrolysis products birch tar oil, wood vinager and biochar in sustainable plant protection - pesticidal effects, soil improvements and environmental risks. PhD dissertation. University of Helsinki, Finland, 2013

308. http://www.pyne.co.uk/Resources/user/PYNE\%20Newsletters/Pynews\%2005.pdf

309. Ito Y, Kawamoto H, Saka S: Efficient and selective hydrogenation of aqueous acetic acid on $\mathrm{Ru}-\mathrm{Sn} / \mathrm{TiO}_{2}$ for bioethanol production from lignocellulosics. Fuel, 2016, 178, 15, 118 123

310. Hedlund JK, Cronauer DC, Jacobs G, Kropf J, Libera JA, Elam JW, Marshall CL, Pendyala VRR, Davis BH: Titania Supported Ru Nanoclusters as Catalysts for Hydrogenation of Pyrolysis Oils. Catalysis Letters, 2016, 146, 2, pp. 525-539

311. Olcay H, Xu L, Xu Y, Huber GW: Aqueous phase Hydrogenation of Acetic Acid over Transition Metal Catalysts. ChemCatChem 2010, 1420-1424

312. Varley, J. B.; Hansen, H. A.; Ammitzbøll, N. L.; Grabow, L. C.; Peterson, A. A.; Rossmeisl,J.; Nørskov, J. K. Ni-Fe-S Cubanes in CO2 Reduction Electrocatalysis: A DFT Study. ACS Catal. 2013, 3, 2640-2643.

313. Liu C, Sun J, Smith C, Wang Y: A study of ZnxZryOz mixed oxides for direct conversion of ethanol to isobutene. Applied Catalysis A; General 467 (2013) 91-97

314. Snell RW, Shanks BH: Insights into the Ceria-Catalyzed Ketonization Reaction for Biofuels Applications, ACS Catal., 2013, 3 (4), 783-789

315. Pacchioni G, Ketonization of Carboxylic Acids in Biomass Conversion over TiO2 and ZrO2 Surfaces: A DFT Perspective. ACS Catal., 2014, 4, 2874-2888.

316. Tago T, Konno H, Sakamoto M, Nakasaka Y, Masuda T, Selective synthesis for light olefins from acetone over ZSM-5 zeolites with nano- amd macro-crystal sizes. Appl. Catal., A, 2011, 403, 183-191.

317. Tago T, Konno H, Nakasaka Y, Masuda T, Size-controlled Synthesis of Nano-Zeolite and Their Applications to Light Olefin Synthesis. Catal. Surv. Asia, 2012, 16, 148-163. 
318. Biaglow A, Sepa J, Gorte R, White D: A 13C-NMR study of the Condensation Chemistry of Acetone and Acetaldehyde Adsorbed at the Bronsterd Acid Sites in H-ZSM-5. J. Catal., 1995, 151, 373-384.

319. Hutchings GJ, Johnston P, Lee DF, Williams CD: Acetone conversion to isobutene in high selectivity using zeolite $\beta$ catalyst. Catal. Lett., 1993, 21, 49-53.

320. Sun J, Zhu K, Gao F, Wang C, Liu J, Peden CH, Wang Y: Direct Conversion of Bioethanol to Isobutene on Nanosized ZnxZryOz Mixed Oxides with Balanced Acid-Base Sites. J. Am. Chem. Soc. 2011, 133, 11096-11099

321. Liu C, Sun J, Smith C, Wang Y: A study of ZnxZryOz mixed oxides for direct conversion of ethanol to isobutene. Applied Catalysis A; General. 2013, 467, 91-97

322. Sun J, Baylon RAL, Liu C, Mei D, Martin KJ, Venkitasubramanian P, Wang Y: Key Roles of Lewis Acid-Base Pairs on ZnxZryOz in direct Ethanol/Acetone to Isobutene Conversion. J. Am. Chem. Soc. 2016, 138, 507-517

323. Qu W, Xue Y, Gao Y, Rover M, Bai X: Repolymeriation of pyrolytic lignin for producing carbon fiber with improved properties. Biomass and Bioenergy, 95, 2016, 1926

324. Liu J, Qu W, Xie Y, Zhu B, Wang T, Bai X, Wang X: Thermal conductivity and annealing effect on structure of lignin based microscale carbon fibers. Carbon, 2017, 121, $35-47$

325. Kadla JF, Kubo S: Lignin-based polymer blends: analysis of intermolecular interactions in lignin-synthesis polymer blends. Compos. Part A, (2004), 35A, 395-400.

326. Thunga M, Chen K, Grewell D, Kessler MR: Biorenewable precursor fibers from lignin/polyactide blends for conversion to carbon fibers. Carbon 68 (2014) 159-166

327. Cerny, M. (1969). Collect. Czech. Chem. Commun. 34:849-856.

328. Cerny, M. (1994). 1,6:2,3 and 1,6:3,4-dianhydro-b-D-hexopyranoses:Synthesis and preparative applications. In: Levoglucosenone and Levoglucosans, Chemistry and Applications, Ed. ZJ Witczak. ATL Press, pp121-146.

329. Witczak Z: Levoglucosenone and Levogluocosans: Chemistry and Applications, 1994

330. Berman, E. (1994). New glucose polymers. In: Levoglucosenone and Levoglucosans, Chemistry and Applications, Ed. ZJ Witczak. ATL Press, pp189-214. 
331. Holmberg, A.L., et al., Softwood Lignin-Based Methacrylate Polymers with Tunable Thermal and Viscoelastic Properties. Macromolecules, 2016. 49(4): p. 1286-1295.

332. Aspinall, G.O., McDonald, A.G., Sood, R.K. (1994) Syntheses of methyl glycosides of 6 deoxyheptoses. Canadian Journal of Chemistry, 72: 247-251.

333. Chen, R., et al., Biobased Ternary Blends of Lignin, Poly(Lactic Acid), and Poly(Butylene Adipate-co-Terephthalate): The Effect of Lignin Heterogeneity on Blend Morphology and Compatibility. Journal of Polymers and the Environment, 2014. 22(4): p. 439-448.

334. Llevot, A., et al., From Lignin-derived Aromatic Compounds to Novel Biobased Polymers. Macromolecular Rapid Communications, 2016. 37(1): p. 9-28.

335. Marinangeli R, Marker T, Petri J, Kalnes T, McCall M, Mackowiak D, Jerosky B, Reagan B, Nemeth L, Krawczyk M, Czernik S, Elliott D, Shonnard D: Opportunities for biorenewables in oil refineries: Final technical Report. Submitted to the US Department of Energy. UOP DOE award: DE-FG36-05G015085, 2005

336. Meister, J.J. and M.J. Chen, Thermoplastic Copolymers of Lignin and Styrene. Abstracts of Papers of the American Chemical Society, 1992. 203: p. 111-CELL.

337. Ragauskas, A.J., et al., Lignin Valorization: Improving Lignin Processing in the Biorefinery.Science, 2014. 344(6185): p. 709-+.

338. Sadeghifar, H., C.Z. Cui, and D.S. Argyropoulos, Toward Thermoplastic Lignin Polymers. Part 1. Selective Masking of Phenolic Hydroxyl Groups in Kraft Lignins via Methylation and Oxypropylation Chemistries. Industrial \& Engineering Chemistry Research, 2012. 51(51): p. 16713-16720.

339. Saito, T., et al., Development of lignin-based polyurethane thermoplastics. Rsc Advances, 2013. 3(44): p. 21832-21840.

340. Zhou S, Garcia-Perez M, Pecha B, Kersten SRA, McDonald AG, Westerhof RJM: Effect of the Fast Pyrolysis Temperature on the Primary and Secondary Products of Lignin. Energy Fuels, 2013, 27 (10), 5867-5877

341. Gellerstedt, G., et al., Chemical Structures Present in Biofuel Obtained from Lignin. Energy \& Fuels, 2008. 22(6): p. 4240-4244. 
342. Luebben, S.D. and J.W. Raebiger, A Novel Renewable Thermoplastic Polyacetal by Polymerization of Glycolaldehyde Dimer, a Major Product of the Fast Pyrolysis of Cellulosic Feedstock. Green Polymer Chemistry: Biobased Materials and Biocatalysis, 2015. 1192: p. 305-328.

343. Sahaf A, Laborie M-P G, Englund K, Garcia-Perez M, McDonald AG: Rheological Properties and Tunable Thermoplasticity of Phenolic Rich Fraction of Pyrolysis Bio-Oil. Macromolecules 2013, 14 (4), 1132-1139

344. Bleeker M, Gorter S, Kersten SRA, van der Ham L, van den Berg H, Veringa H: Hydrogen production from pyrolysis oil using the steam-iron process: a process design study. 2010, 12, 125-135

345. Valiente A, Medrano JA, Oliva M, Ruiz J, Garcia L, Arauzo J: Bioenergy II: Hydrogen Production by Aqueous-Phase Reforming. International Journal of Chemical Reactor Engineering, 2010, 8, 1

346. Czernik S, French R, Feik C, Chornet E: Fluidized bed catalytic steam reforming of pyrolysis oil for production of hydrogen. United Kingdom, N.p. 1989, Web

347. Davidian, T., Guilhaume, N., Iojoiu, E., Provendier, H., Mirodatos, C., Applied Catalysis B: Environmental, 2007; 73: 116-123.

348. Galdamez JR, Garcia L, Bilbao R: Hydrogen Production by Steam Reforming of Bio-oil using coprecipitated Ni-Al Catalysts. Acetic Acid as a Model Compound. Energy Fuels, 2005, 19 (3), 1133-1142

349. Rioche C, Kulkami S, Meunier FC, Breen JP, Burch R: Steam reforming of model compounds and fats pyrolysis bio-oil on supported noble metal catalysts, Applied Catalysis B: Environmental, 2005, 61, 1-2, 130-139

350. Takanabe K, Aika K, Seshan K, Lefferts L: Sustainable hydrogen from bio-oil - Steam reforming of acetic acid as a model oxygenated. Journal of Catalysis, 2004, 227, 1, 101108

351. Wang D, Czernik S, Montane D, Mann M, Chornet E: Biomass to Hydrogen via Fast Pyrolysis and Catalytic Steam Reforming of the Pyrolysis Oil and its fractions. Ind. Eng. Chem. Res. 1997, 36 (5), 1507-1518 
352. Wang D, Czernick S, Chornet E: Production of Hydrogen from Biomass by Catalytic Steam Reforming of Fast Pyrolysis Oils. Energy Fuels, 1998, 12 (1), 19-24

353. Wang, Z., Pan, Y., Dong, T., Zhu, X., Kan, T., Yuan, L., Torimoto, Y., Sadakata, M., Li, Q., Production of hydrogen from catalytic steam reforming of bio-oil using C12A7-O-based catalysts. Appl. Catal. A, 2007; 320: 24-34.

354. Van Rossum G, Kersten SRA, van Swaaij WPM: Catalytic and Non-catalytic Gasification of Pyrolysis Oil. Ind. Eng. Chem. Res. 2007, 46 (12), 3959-3867

355. Miyafiji H, Nakata T, Ehara K, Saka S: Fermentability of Water-Soluble Portion of Ethanol Obtained by Supercritical Water Treatment of Lignocellulosics. Twenty-Sixth Symposium on Biotechnology for Fuels and Chemicals, 963-971

356. Olson ES, Freel B: Process for Converting anhydrosugars to glucose and other fermentable sugars, US Patent 2007/0125369 A1

357. Prosen EM, Radlein D, Pskorz J, Scott DS, Legge RL: Microbial utilization of levoglucosan in wood pyrolysate as a carbon and energy source. Biotechnology and Bioeneginering, 1993, 42, 538-541

358. Shafizadeh F, Stevenson TT: Saccharification of douglas-fir wood by a combination of prehydrolysis and pyrolysis. 1982, 4577-4585

359. Falcon-Hernandez J, Carbonell-Morla J: Fuel Emulsions Using Biomass Pyrolysis Products as an Emulsifier Agent. Energy \& Fuels, 2003, 17 92), 302-307

360. Loo AY, Jain K, Darah I: Antioxidant activity of compounds isolated from the pyroligneous acid, Rhizophora apiculate. Food Chemistry, 2008, 107, 3, 1151-1160

361. Dobele, G., Dizhbite, T., Urbanovich, I., Andersone, A., Ponomarenko, J., Telysheva, G., 2009. Pyrolytic oil on the basis of wood and the antioxidant properties of its watersoluble and -insoluble fraction. J. Anal. Appl. Pyrolysis, Pyrolysis 2008Papers presented at the 18th International Symposium on Analytical and Applied Pyrolysis 85, 81-86. doi:10.1016/j.jaap.2008.12.006

362. Kamat, J.P., Ghosh, A., Devasagayam, T.P.A., 2000. Vanillin as an antioxidant in rat liver mitochondria: Inhibition of protein oxidation and lipid peroxidation induced by photosensitization. Mol. Cell. Biochem. 209, 47-53 
363. Ito, M., Murakami, K., Yoshino, M., 2005. Antioxidant action of eugenol compounds: role of metal ion in the inhibition of lipid peroxidation. Food Chem. Toxicol. 43, 461466.

364. Yogalakshmi, B., Viswanathan, P., Anuradha, C.V., 2010. Investigation of antioxidant, anti-inflammatory and DNA-protective properties of eugenol in thioacetamide-induced liver injury in rats. Toxicology, This issue includes a Special Issue Section on: Highlights of the 2009 Annual Congress of The British Toxicology Society 268, 204-212.

365. Bang, S.-H., Han, S.-J., Kim, D.-H., 2008. Hydrolysis of arbutin to hydroquinone by human skin bacteria and its effect on antioxidant activity. J. Cosmet. Dermatol. 7, 189193.

366. Garcia M, Botella L, Gil-Lalaguna N, Arauzo J, Gonzalo A, Sanchez JL: Antioxidants for biodiesel: Additives prepared from extracted fractions of bio-oil. Fuel Processing Technology. 156 (2017) 407-414

367. Gil-Lalaguna N, Bautista A, Gonzalo A, Sanchez JL, Arauzo J: Obtaining biodiesel antioxidant additives by hydrothermal treatment of lignocellulosic bio-oil. Fuel Processing Technology, 166, 2017, 1-7

368. Yang X, You Z-P, Dai Q-L: Performance evaluation of Asphalt Binder Modified by Biooil Generated from Waste Wood Resources. International Journal of Pavement Research and Technology, 2013, 431-439

369. Hill DR, Jennings AA: Bioasphalt from Urban Yard Waste Carbonization: A student Study. Caste Western Reserve University, 2011, Report to the Ohio Department of Transportation, FHWA/OH-2011-13

370. Yang X, You Z, Mills-Beale J: Asphalt Binders Blended with a High Percentage of Biobinders: Aging Mechanism Using FTIR and Rheology, Journal of Materials in Civil Engineering, 2015, 27, 4, 04014157

371. Qin W, Kadla JF: Carbon Fibers based on pyrolytic lignin. Journal of Applied Polymer Science, 126, S1, E204-E213

372. Sun J, Baylon RA, Liu C, Mei D, Martin KJ, Venkitasubranaian P, Wang Y: Key role of Lewis Acid-Base Pairs on ZnxZryOz in direct ethanol/Acetone to Isobutene Conversion. J. Am. Chem. Soc. 2016, 138 (2), 507-517 
373. Elliott DC, Neuenschwander GG, Hart TR: Hydroprocessing Bio-oil and Product Separation for Coke Production, ACS Sustainable Chem. Eng., 2013, 1, 4, 389-392

374. Dooley, K.M., Bhat, A.K., Plaisance, C.P., Roy, A.D. Ketones from acid condensation using supported $\mathrm{CeO}_{2}$ catalysts: Effect of additives. Applied Catalysis A: General, 2007; 320: $122-133$.

375. Pulido, A., Oliver-Tomas, B., Renz, M., Boronat, M. Corma, A. Ketonic decarboxylation reaction mechanism: A combined experimental and DFT study. ChemSusChem, 2013; 6: 141-151.

376. Glinski. M., Zalewski, G., Burno, E., Jerzak, A. Catalytic ketonization over metal oxide catalysts. XIII. Comparative measurements of oxides of 32 chemical elements in ketonization of propanoic acid. Applied Catalysis A: General, 2014; 470: 278-284.

377. Snell RW, Shanks BH, Insights into the ceria-Catalyzed Ketonization reaction for Biofuels Applications. ACS Catal., 2013, 3, 783-789.

378. Sundqvist, T., Oasmaa, A., Koskinen, A. Upgrading fast pyrolysis bio-oil quality by esterification and azeotropic water removal. Energy and Fuels, 2015; 29: 2527-2534.

379. Schulzke, T., Conrad, S., Kaluza, S., Van Loo, T. Upgrading of fast pyrolysis condensates via esterification with higher alcohols. Biomass \& Bioenergy, 2017; 103: 1120.

380. Elliott DC, Hart TR: Catalytic Hydroprocessing of Chemical Models for Bio-oil. Energy \& Fuels 2009, 23, 631-637

381. Wan H., Chaudhari R.V., Subramaniam B. Aqueous Phase Hydrogenation of Acetic Acid and Its Promotional Effect onp-Cresol Hydrodeoxygenation, Energy \& Fuels, 2013, 27, 487-493.

382. Rachmady W. and Vannice M., Acetic acid hydrogenation over supported platinum catalysts. J. Catal., 2000, 192, 322-334

383. Nozawa, T., Mizukoshi, Y., Yoshida, A., Naito, S. Aqueous phase reforming of ethanol and acetic acid over $\mathrm{TiO}_{2}$ supported $\mathrm{Ru}$ catalysts. Applied Catalysis B: Environmental, 2014; 146: 221-226.

384. Chen J, Sun J, Wang Y: Catalysts for Steam reforming of Bio-oil: A Review, Ind. Eng. Chem. Res., 2017, 56 (16), 4627-4637 
385. Trane-Restrup, R., Resasco, D.E., Jensen, A.D. Steam reforming of light oxygenates. Catalysis Science \& Technology, 2013; 3: 3292-3302.

386. Bimbela, F., Ábrego, J., Puerta, R., García, L, Arauzo, J. Catalytic steam reforming of the aqueous fraction of bio-oil using $\mathrm{Ni}-\mathrm{Ce} / \mathrm{Mg}-\mathrm{Al}$ catalysts. Applied Catalysis B: Environmental, 2017; 209: 346-357.

387. Boateng AA, Dauggard DE, Goldberg NM, Hicks KB: Bench scale Fluidized-Bed Pyrolysis of Switchgrass for Bio-oil production. Ind. Eng. Chem. Res., 2007, 46 (7), 1891-1897

388. Dasari, M.A., Kiatsimkul, P.-P., Sutterlin, W. R., Suppes, G.J. Low-pressure hydrogenolysis of glycerol to propylene glycol. Applied Catalyst: A: General, 2005; 281: $225-231$.

389. Chui C-W, Dasari MA, Supper GJ, Sutterlin WR: Dehydration of glycerol to acetol via catalytic reactive distillation. AIChE Journal, 2006, 52, 10, 3543-3548

390. Yuan, Z., Wu, P., Gao, J., Lu, X., Hou, Z., Zheng, X. Pt/Solid-base: A predominant catalyst for glycerol hydrogenolysis in a base-free aqueous solution. Catalysis Letters, 2009; 130: 261-265.

391. Montes, V., Boutonnet, M., Järas, S., Marinas, A., Marinas, J.M., Urbano, F.J. Selective transformation of glycerol into 1,2-propanediol on several $\mathrm{Pt} / \mathrm{ZnO}$ solids: further insight into the role and origin of catalyst acidity. Catalysis Today, 2015; 257: 246-258.

392. Pathak, K.D., Catalytic conversion of glycerol to value-added liquid chemicals. Master's Thesis, University of Saskatchewan, Saskatoon, Saskatchewan, Canada, 2005.

393. Puckette TA, Devon TJ: Process for the preparation of Glycoaldehyde. US Patent, 7, 420, 093 B2 (Sept 2, 2008)

394. Zhao G, Zheng M, Zhang J, Wang A, Zhang T: Catalytic conversion of Concentrated Glucose to Ethylene Glycol with Semicontinuous Reaction System. Ind. Eng. Chem. Res., 2013, 52 (28), 9566-9572

395. Underwood, G. L., Graham, R. G. Methods of using fast pyrolysis liquids as liquid smoke. U.S. Patent 4,876,108, Oct. 24, 1989

396. Li, L., Zhang, H. Preparing levoglucosan derived from waste material by pyrolysis. Energy Sources, 2004; 26: 1053-1059. 
397. Yu, Z., Zhang, H. Ethanol fermentation of acid-hydrolyzed cellulosic pyrolysate with Saccharomyces cerevisiae. Bioresource Technology, 2004; 93: 199-204.

398. Longley, C. J., Fung, D. P. C. Potential Applications and Markets for Biomass-Derived Levoglucosan, in: Advances in Thermochemical Biomass Conversion, 1994; 2: 14841494.

399. Dale, B. E.; Artzen, C. E. Biobased industrial products: Research and commercialization priorities. National Research Council, Washington, 1999.

400. Huber, G. W., Iborra, S., Corma, A., Synthesis of transportation fuels from biomass: chemistry, catalysts, and engineering. Chem. Rev., 2006; 106: 4044-4098.

401. Sheldon, R.A. Utilization of biomass for sustainable fuels and chemicals: Molecules, methods and metrics. Catalysis Today, 2011; 167: 3-13.

402. Tong, X., Ma, Y., Li, Y. Biomass into chemicals: Conversion of sugars to furan derivatives by catalytic processes. Applied Catalysis A: General, 2010; 385: 1-13.

403. Rover MR, Brown RC: Quantification of total phenols in bio-oil using the FolinCiocalteu method. Journal of Analytical and Applied Pyrolysis, 2013, 104, 366-371

404. Rudnick LR: Lubricant Additives. Chemistry and Applications, Third Edition, 2017, Boca Raton, CRC Press, 707 pages.

405. Huang, H.-J., Ramaswamy, S., Tschirner, U. W., Ramarao, B. V. A review of separation technologies in current and future biorefineries. Separation and Purification Technology, 2008; 62: 1-21.

406. Amen-Chen C, Riedl B, Wang XM, Roy C: Softwood Bark Pyrolysis Oil-PF Resols. Part 1. Resin Synthesis and OSB Mechanical Properties, Holzforchung, 2002, 56, 2, 167-175

407. Amen-Chen C, Riedl B, Roy C: Softwood Bark Pyrolysis Oil-PF Resols. Part 2. Thermal Analysis by DSC and TG, 2005, 56, 3, 273-280

408. Radlein, D., Quignard, A. Methods of upgrading biooil to transportation grade hydrocarbon fuels. US Pat. 2014/0288338, 2014.

409. Asadieraghi, M., Wan Daud, W.M.A., Abbas, H.F. Model compound approach to design process and select catalysts for in-situ bio-oil upgrading. Renew. Sust. Energ. Rev, 2014; 36: 286-303. 
410. Cherubini, F., Jungmeier, G., Wellisch, M., Wilke, T., Skiadas, I., van Ree, R., de Jong, E. Toward a common classification approach for biorefinery systems. Biofuels, Bioproducts \& Biorefining, 2009; 3: 534-546.

411. Cortritght, R.D., Davda, R.R., Dumesic, J.A. Hydrogen from catalytic reforming of biomass-derived hydrocarbons in liquid water. Nature, 2002; 418: 964-967.

412. Shabaker, J.W., Huber, G.W., Dumesic, J.A. Aqueous-phase reforming of oxygenated hydrocarbons over Sn-modified Ni catalysts. Journal of Catalysis, 2004; 222: 180-191.

413. Gaertner, C.A., Serrano-Ruiz, J.C., Braden, D.J., Dumesic, J.A. Catalytic coupling of carboxylic acids by ketonization as a processing step in biomass conversion. Journal of Catalysis, 2009; 266: 71-78.

414. Pham, T.N., Shi, D., Sooknoi, T., Resasco, D.E. Aqueous-phase ketonization of acetic acid over $\mathrm{Ru} / \mathrm{TiO}_{2} /$ carbon catalysts. Journal of Catalysis, 2012; 295: 169-178.

415. Gangadharan, A., Shen, M., Sooknoi, T., Resasco, D.E., Mallinson, R.G. Condensation reactions of propanal over $\mathrm{Ce}_{\mathrm{x}} \mathrm{Zr}_{1-\mathrm{x}} \mathrm{O}_{2}$ mixed oxide catalysts. Applied Catalysis A:General, 2010; 385: 80-91.

416. Faba, L., Díaz, E., Ordóñez, S. Aqueous-phase furfural-acetone aldol condensation over basic mixed oxides. Applied Catalysis B: Environmental, 2012; 113-114: 201-211.

417. Hora, L., Kelbichová, V., Kikhtyanin, O., Bortnovskiy, O., Kubicka, D. Aldol condensation of furfural and acetone over MgAl layered double hydroxides and mixed oxides. Catalysis Today, 2014; 223: 138-147.

418. Di Cosimo, J.I., Diez, V.K., Apesteguía, C.R. Base catalysis for the synthesis of $\alpha, \beta-$ unsaturated ketones from the vapor-phase aldol condensation of acetone. Applied Catalysis A: General, 1196; 137: 149-166.

419. Faba, L., Díaz, E., Ordóñez, S. Gas phase acetone self-condensation over unsupported and supported Mg-Zr mixed-oxides catalysts. Applied Catalysis B: Environmental, 2013; 142-143: 387-395.

420. Nguyen T.D., Kikhtyanin, O., Ramos, R., Kothari, M., Ulbrich, P., Munshi, T., Kubicka, D. Nanosized $\mathrm{TiO}_{2}$-A promising catalyst for the aldol condensation of furfural with acetone in biomass upgrading. Catalysis Today, 2016; 277: 97-107. 
421. Wang, S., Goulas, K., Iglesia, E. Condensation and esterification reactions of alkanals, alkanones and alkanols on $\mathrm{TiO}_{2}$ : Elementary steps, site requirements, and synergistic effects of bifunctional strategies. Journal of Catalysis, 2016; 340: 302-320.

422. Wang, S., Iglesia, E. Experimental and theoretical assessment of the mechanism and site requirements for ketonization of carboxylic acids on oxides. Journal of Catalysis, 2017; 345: 183-206.

423. Hakim, S.H., Shanks, B.H., Dumesic, J.A. Catalytic upgrading of the light fraction of a simulated bio-oil over CeZrOx catalyst. Applied Catalysis B: Environmental, 2013; 142143: 368-376.

424. Fernández-Arroyo, A., Delgado, D. Domine, M.E., Lopez-Nieto, J.M. Upgrading of oxygenated compounds present in aqueous biomass-derived feedstocks over NbOx-based catalysts. Catalysis Sciencie \& Technology, 2017; DOI: 10.1039/C7CY00916J.

425. Domine, M.E., López-Nieto, J.M., Delgado, D., Fernández-Arroyo, A. Method for recovering the oxygenated compounds contained in aqueous fractions derived from biomass. WO 2017162900, Mar 22, 2017

426. Mija A, van der Waal JC, Pin J-M, Guigo N, de Jong E: Humins as promising material for producing sustainable carbohydrate-derived building materials. Construction and Building Materials, 139, 2017, 594-601

427. Muralidhara A, Bado-Nilles A, Marlair G, Engelen V, Len C, Pandard P: Humins in the environment: early stage insights on ecotoxicological aspects. Biofuels, Bioproducts \& Biorfining, 2018, DOI: 10.1002/bbb.1964 